Portland State University

PDXScholar

$1-1-2012$

\title{
Agency, Consolidation, and Consequence: Evaluating Social and Political Change in New Orleans, 1868-1900
}

Christopher Joseph Cook

Portland State University

Follow this and additional works at: https://pdxscholar.library.pdx.edu/open_access_etds Let us know how access to this document benefits you.

Recommended Citation

Cook, Christopher Joseph, "Agency, Consolidation, and Consequence: Evaluating Social and Political Change in New Orleans, 1868-1900" (2012). Dissertations and Theses. Paper 535.

https://doi.org/10.15760/etd.535

This Thesis is brought to you for free and open access. It has been accepted for inclusion in Dissertations and Theses by an authorized administrator of PDXScholar. Please contact us if we can make this document more accessible: pdxscholar@pdx.edu. 
Agency, Consolidation, and Consequence:

Evaluating Social and Political Change in New Orleans,

$1868-1900$

by

Christopher Joseph Cook

A thesis submitted in partial fulfillment of the requirements for the degree of

Master of Arts

in

History

Thesis Committee:

David Horowitz, Chair

Tim Garrison

Patricia Schechter

Touetu Faaleava

Portland State University

(C) 2012 


\begin{abstract}
In the last twenty years, recent scholarship has opened up fresh inquiry into several aspects of New Orleans society during the late nineteenth century. Much work has been done to reassess the political and cultural involvement, as well as perspective of, the black Creoles of the city; the successful reordering of society under the direction of the Anglo-Protestant elite; and the evolution of New Orleans's social conditions and cultural institutions during the period initiating Jim Crow segregation. Further exploration, however, is necessary to make connections between each of these avenues of study. This thesis relies on a variety of secondary sources, primary legal documents, and contemporary newspaper articles and publications, to provide connections between the above topics, giving each greater context and allowing for the exploration of several themes. These include the direction of black Creole public ambition after the end of that community's last civil rights crusade, the effects of Democratic Party strategy and the Lost Cause of the Confederacy movement on younger generations of white residents, and the effects of changing social expectations and increasing segregation on the city's diverse ethnic immigrant community. In doing so, this thesis will contribute to enhancing the current understanding of New Orleans's complex and changing social order, as well as provide future researchers with a broad based work which will effectively introduce the exploration of a variety of key topics and serve as a bridge to connect them with specific lines of inquiry while highlighting the above themes in order to make new connections between various facets of the city's troubled racial history.
\end{abstract}




\section{Contents}

$\begin{array}{lc}\text { Abstract } & \mathrm{i} \\ \text { Introduction } & 1 \\ \text { Chapter 1: Ambition and History: The Black Creole Experience } & 12 \\ \text { Chapter 2: White Consolidation and Influence } & 42 \\ \text { Chapter 3: The Consequences of Social Change } & 78 \\ \text { Conclusion } & 109 \\ \text { Bibliography } & 114\end{array}$ 


\section{Introduction}

When the federal military government began preparations to convene a constitutional convention and readmit Louisiana to the Union in 1864, black leaders gathered at Economy Hall in New Orleans to draft a petition for their inclusion in the new political system. The meeting was dominated by radical black Creoles, but it also included more pragmatic African American leaders educated in the North, such as P.B.S. Pinchback. ${ }^{1}$ When their request that people of color free before the Civil War be granted suffrage was ignored by army officials in Louisiana, Economy Hall delegates sent two prominent black Creole representatives to Washington, D.C. to petition President Abraham Lincoln and Congress directly. At the urging of Republican Senator Charles Sumner of Massachusetts, black Creole radicals would amend their petition to plead for the voting rights of all black Louisianans, regardless of previous servitude. ${ }^{2}$ Despite the pleas of New Orleans's black community, however, the constitutional convention of 1864 was for whites only, comprised mainly of moderate New Orleans based Unionists. ${ }^{3}$ The document they wrote, often referred to as the Free State Constitution, acknowledged Emancipation, but only "allowed" for black suffrage at some point in the future. ${ }^{4}$

\footnotetext{
${ }^{1}$ Ted Tunnell, Crucible of Reconstruction: War, Radicalism, and Race in Louisiana, 1862-1877 (BatonRouge: Louisiana State University Press, 1984), 76. Ibid.: 78.

${ }^{3}$ Hollandsworth, James G. Jr. An Absolute Massacre: The New Orleans Race Riot of July 30, 1866. (Baton Rouge, 2001) 19.

${ }^{4}$ Ibid.: 26.
} 
Once the constitution was ratified, and ex-Confederates began returning to state politics after the war under President Andrew Johnson's lenient post-war policy, Louisiana radicals pushed to reconvene the constitutional convention in an attempt to consolidate power. By then, New Orleans had been repopulated by Confederate veterans, some of whom joined secret societies such as the Knights of the White Camellia, an early forerunner of the White League which would later consolidate power for the Democratic Party. Confederate veterans even had re-elected former mayor John T. Monroe, also a former Confederate as well as a veteran of the nativist "Know Nothing" party of the $1850 \mathrm{~s} .^{5}$ In control of city government and the Metropolitan Police, ex-Confederates refused to allow a pro-suffrage convention. As supporters of black suffrage filed into the Mechanics' Institute when the convention reconvened in July 1866, therefore, a large crowd of ex-Confederates, including many armed police officers (who were usually only allowed to carry nightsticks), gathered outside the building. When a procession of black supporters of the convention led by black Creole Union veterans, who were also armed, arrived at the hall after a march originating in a downtown neighborhood, it did not take long for trouble to start. ${ }^{6}$ Both sides had members who had been drinking, some celebrating the convention and others in anger, and hot tempers prevailed. ${ }^{7}$ Once the fighting started, however, the crowd of black veterans was quickly overrun by the larger white group, which ran rampant across town looting homes and beating random black residents through the afternoon. Members of

\footnotetext{
${ }^{5}$ Hollandsworth, An Absolute Massacre, 103.

${ }^{6}$ Ibid.:100.

${ }^{7}$ Ibid:: 101 .
} 
the white mob that lingered in front of the Mechanics' Institute, many of them well armed police officers, advanced into the hall three times, once under a truce, to attack the delegates. ${ }^{8}$

The 1866 New Orleans Race Riot is representative of the volatile social situation created across the South at the close of the Civil War, as communities and governments grappled with not only the consequences of the war, but, more importantly, Emancipation. However, the violence of the riot, while endemic to most of the South after the Civil War, is an anomaly in the course of New Orleans's history. After 1866, rather than becoming mired in vicious reprisals and intimidation, the city progressed through a series of impromptu compromises and equilibriums, including two sizable attempts to secure the protection of equal civil rights under the law, before arriving at the strict Jim Crow segregation established in the late 1890s. Consequently, the riot of 1866 is a fitting place to begin a study of the two competing strategies at work to establish a new order amidst the power vacuum left by the war and the factions behind them.

The role of the black Creoles in nineteenth century New Orleans, in particular their political involvement, class-consciousness, and relationship with African Americans, builds on a scholarly lineage established by Joseph G. Tregle, Jr.'s 1952 journal article, "Early New Orleans Society: A Reappraisal," which called into question the definition of the term Creole as it was established in the early twentieth century. ${ }^{9}$ Tregle's use of compelling documentary evidence established a new level of inquiry into

\footnotetext{
${ }^{8}$ Hollandsworth, An Absolute Massacre, 109.

9 Joseph G. Tregle, Jr., "Early New Orleans Society: A Reappraisal," Journal of Southern History 18, No.1 (February 1952): 20-36.
} 
the gens de couleur libre of Louisiana, and dispelled the notion established by Charles Gayarré and Alcée Fortier that Creole could only apply to black Louisianans as an adjective denoting place of origin; often compared to the title assigned to creole tomatoes. Though Tregle began the inquiry into this largely self-defined group no scholarship has been brought forth to dispute the application of the ethnic identity Creole to Louisiana's largely mixed-race, historically free, predominately Catholic, and French-speaking black population. ${ }^{10}$ This emphasis on recognizing and exploring black Creole heritage has been expanded by the study of immigration to New Orleans by white, black, and mixed-race refugees of the Haitian Revolution.

Forty years later, Arnold R. Hirsch and Joseph Logsdon's anthology, Creole New Orleans: Race and Americanization (1992), continued this inquiry into the role of the city's black Creoles in greater depth. Directly related to the lineage of the above scholars are Caryn Cossé Bell's Revolution, Romanticism, and the Afro-Creole Protest Tradition in Louisiana, 1718-1868 (1997) and Rebecca J. Scott's 2005 Degrees of Freedom: Louisiana and Cuba After Slavery (2005), which opened similar lines of inquiry regarding the late nineteenth century. All of these works have centered on the agency of the black Creole community, as well as the many social determinates and organic compromises in status, such as tolerance for interracial marriage and economic involvement in skilled crafts and small business, which contributed to its successes and survival. These works portray the black Creoles as a historic people, eager to build on the accomplishments in the struggle for equality of their forbearers, many of whom

\footnotetext{
10 Joseph G. Tregle, Jr., “On That Word 'Creole’ Again: A Note,” Louisiana History 23, No. 2 (Spring
} 1982): 193, 197. 
fought in the American Revolution, by way of the Spanish invasion of West Florida, as well as in the Battle of New Orleans during the War of 1812. Similarly, the strong economic position of the black Creoles is emphasized by these works, along with the high levels of literacy, knowledge of world events, and pride which economic success facilitates.

Consideration of the white elite's participation in white supremacist political and social movements of the period, including the motivations and mechanisms of Redemption and Jim Crow segregation, has benefitted from recent scholarly reassessment of the Lost Cause of the Confederacy. ${ }^{11}$ They include James G. Gill's Lords of Misrule: Mardi Gras and the Politics of Race in New Orleans (1997), which describes an evolving white elite ethos from the back rooms of exclusive clubs to the concrete events that not only disseminated white supremacist ideals, but also strengthened them. Ted Tunnell's Crucible of Reconstruction: War, Radicalism, and Race in Louisiana, 1862-1877 (1984) is remarkable for its reassessment of the narrative of Reconstruction, and provides in depth discussions of the work of both white and black leaders, along with novel assessments of their motivations, during the period.

A pan-Southern perspective on Redemption and the Lost Cause appears in Edward J. Blum's Reforging the White Republic: Race, Religion, and American Nationalism, 1865-1898 (2005), David W. Blight's Race and Reunion: The Civil War in

${ }^{11}$ In this work, the terms Redemption and Jim Crow are used generally to describe certain periods. Redemption, a term referring to the Democratic takeover of local and state governments across the South after Reconstruction, is used in this paper to describe the period of the 1876 election cycle and the 1879 state constitution. Jim Crow is used in this paper to describe the implementation of strict bi-racial segregation, specifically the period after the ratification of the 1898 state constitution. The term Lost Cause is used to describe the strategy of enshrining Confederate nostalgia beginning during the period of Redemption and continuing into the twentieth century. 
American Memory (2001), and Tunnell's journal article "Creating 'The Propaganda of History': Southern Editors and the Origins of 'Carpetbagger and Scalawag” (2006). While these works give little attention to New Orleans, they are important in their reassessment of the motivations and mechanisms of Redemption and the Lost Cause which ultimately radicalized white society in the years after the Democratic takeover of governments across the South, paving the way for the strict segregation of Jim Crow in the 1890 s, as well as the increased violence which accompanied it. Similarly, these works also share a reliance on C. Van Woodward's groundbreaking 1955 work, The Strange Career of Jim Crow, building on that exploration of the period by further investigating the motivations and strategy of the white elite and evaluating the process of turning rhetoric into law.

Several works have explored the role of culture in shaping, as well as responding to, the social order of New Orleans. They include Joseph Roach's Cities of the Dead: Circum-Atlantic Performance (1996) and Richard Brent Turner's Jazz Religion, the Second Line, and Black New Orleans (2009). Both seek to explain the power of culture as well as the hidden meanings and historical memories embedded within the rich fabric of the city's more unique cultural institutions. Scholarship on the advent of jazz in this setting includes the work of Lawrence Gushee, Donald Marquis' In Search of Buddy Bolden: First Man of Jazz (1978), Charles Hersch's Subversive Sounds: Race and the Birth of Jazz in New Orleans (2007), and R. Collins' New Orleans Jazz: A Revised History, The Development of American Music from the Origin to the Big Bands (1996). Each of these works investigates social components and influences on cultural 
expression in New Orleans, reassessing previous generalizations about the role of Jim Crow segregation in influencing culture as well as its impact on the lives of musicians. Samuel Charters' well-regarded A Trumpet Around the Corner: The Story of New Orleans Jazz (2008) builds on the above works in establishing context to the social conditions of the city at the turn of the twentieth century, before providing a detailed exploration of the professional lives of New Orleans musicians and the progress of the art-form after the 1900s.

What the historiography of late-nineteenth century New Orleans lacks are the connections between these various fields. Inquiry into the role of black Creoles during the period, covered by Bell, Logsdon, and Scott, essentially stops after the defeat of Plessy v. Ferguson, leaving questions as to the outlet of black Creole public ambition after 1896. Coverage of white elites through Redemption and Jim Crow gives little attention to ethnic immigrants and lacks in assessing the transmission of ideals from one generation to the next. While Gill pays attention to ethnic white immigrants in the 1870s, it becomes important to address how the imposition of Jim Crow segregation impacted groups on the edges of white society. Similarly, while Lawrence N. Powell's journal article "Reinventing Tradition: Liberty Place, Historical Memory, and SilkStocking Vigilantism in New Orleans Politics" (1999) followed trends of influence and the impact on subsequent white generations of the Battle of Liberty Place, no single work has conclusively connected these themes to the 1900 Robert Charles Riot and the 
1898 state constitution. ${ }^{12}$ Regarding the scope of jazz historiography, works which emphasize the state of society at the turn of the twentieth century, such as those by Hersch and Collins, which richly detail the realities of segregation during the period, are lacking in sufficient context of earlier periods. They fail, for example, to connect relevant themes and issues to the narrative of black Creole political involvement, the status of ethnic-white immigrants, and the true impact of segregation on all levels of society.

This thesis seeks to draw connections between these components and fill the gaps outlined in recent scholarship on late-nineteenth century New Orleans and the problematic road to full-scale racial segregation. Hence, it will not only describe the ascendancy of the city's black Creole class and its political downfall in the 1890s, but also contrast that narrative with the successful consolidation of ethnic white New Orleanians under the Democratic Party in the period of Redemption. Beyond the immediate implications of Redemption, this work will explore the effects of that movement on the historical memory of New Orleans, and the ability of that memory to radicalize the city's white population in the period of Jim Crow segregation. Finally, this thesis will assess the social and cultural ramifications of social change in the black and immigrant communities, as a way of providing more concrete insight into the period and its history.

\footnotetext{
12 Lawrence N. Powell, "Reinventing Tradition: Liberty Place, Historical Memory, and Silk-stocking Vigilantism in New Orleans Politics," From Slavery to Emancipation in the Atlantic World, ed. Sylvia R. Frey and Betty Wood (London: Frank Cass Publishers, 1999).
} 
As a work which seeks to unite the scholarship of several fields and show their connections, this paper relies on a large variety of secondary sources detailing topics including politics, society, government, unions, ethnic immigrants, the police force, Carnival, jazz, and secret societies, as well as a number of primary sources. The latter include the publications of the Citizens Committee, and a variety of legal documents including court cases, state constitutions, and the New Orleans civil code. Rounding out a survey of the primary sources are the writings of Rodolphe Desdunes and George Washington Cable; the Daily Picayune, a center-right newspaper selected for its wide coverage of events, availability, and longevity of publication; the New Orleans Crusader, a black Creole publication; the publications of public speeches given before the White League; and the oral histories and memoirs of jazz musicians, who vividly describe, with greater or lesser clarity, the city as it was at the turn of the twentieth century.

Chapter One of the thesis will explore the ascendancy of the black Creole class and its motivations, successes, and failures. In doing so, it ask how the black Creole class was able to build its influence, and why it was ultimately unsuccessful. It will also explore black Creole concepts of social class alongside concepts of equality to assess possible sources of friction between the black Creoles and other groups within New Orleans. Chapter Two seeks to explain why white elites, through the White League and Democratic Party, were so much more successful in achieving their goals than the highly organized black Creole elite. It will also include an assessment of dissenting opinions from within the white community. Nevertheless, the chapter seeks to explain the 
ingredients of white elite strategy, both political and cultural, and their implications on New Orleans's cosmopolitan society as a whole throughout the period.

Chapter Three, in turn, asks how a changing social order affected ethnic immigrants by assessing which ethnic groups were neglected by white consolidation, as well as what effect Jim Crow segregation had on the development of jazz music and other cultural outlets as black New Orleanians navigated a changing social environment. It will further detail how the implementation of a white supremacist social order impacted the public ambition so characteristic of the black Creoles, and explore what the consequences of this tumultuous period were for the relationship between the black Creole and African American communities.

As with other contemporary works investigating the history of New Orleans, this thesis will emphasize the inherent complexities of a city which entered the period of Reconstruction after generations of traditional adaptations to coping with a diverse populace. Thusly, this thesis will explore the slow death of many ground-level accommodations and compromises used by the residents of New Orleans to navigate such a complex social hierarchy, as well as investigating how attitudes toward such practices shifted over time. By 1900, New Orleans had arrived at a level of segregation that matched the strict Jim Crow policies of its neighboring Southern states, but the city's journey to that point is unique.

This is not to say that New Orleans did not participate in regional and national trends, but rather to emphasize how these trends took shape in a dynamic urban center with a distinctive history, population, and culture. Thus, the tide of Redemption in the 
late $1870 \mathrm{~s}$, the relative stability and cooperation found in racial dynamics in the $1880 \mathrm{~s}$, the influence of the Lost Cause mythos, and the return of racial violence shortly before the cementing of Jim Crow in the late 1890s are described not as events unique to New Orleans, but explored to understand how these trends were manifested in a city which presented such a variety of distinguishing variables as a large, wealthy black Creole community and an ever changing and ever increasing ethnic white immigrant population. This thesis also seeks to investigate the effects of these trends on New Orleans society, not only to evaluate the changing status of black Creoles, African Americans, and ethnic white immigrants, but also to explore more unique social and cultural outcomes that evolved in the city. 


\section{Chapter 1:}

\section{Ambition and History: The Black Creole Experience}

One key facet of Louisiana's complexity in the pre-war period was the state's large population of free people of color. Mostly made up of free black Creoles, who were predominantly mixed race, ethnically French, and had been free for generations, this community was based in New Orleans. ${ }^{13}$ In the 1860 census, nearly 11,000 free people of color were recorded in the city, many of which were educated and occupied a near middle-class position as skilled tradesmen and merchants. ${ }^{14}$ This community would develop into a powerful radical influence on state politics during and after the Civil War, though it would be both empowered and limited by its own concepts of race and class. Perhaps more so than any other ethnic group in cosmopolitan New Orleans, the black Creoles were a product of their history.

Throughout the history of New Orleans, the black Creoles had gradually gained rights and autonomy in the city's ethnically stratified society. This process began shortly after the colony's foundation in the early eighteenth century. Early Louisiana was a relative backwater in the French Caribbean trade network, as well as an immense

\footnotetext{
${ }^{13}$ Also referred to as Franco-Africans, or Latin-Negroes, this paper uses the term black Creole to emphasize this community's ties to Louisiana history and culture, their often mixed-race heritage, and to differentiate them from white Creoles.

${ }^{14}$ As a comparison, the neighboring states of Texas, Mississippi, and Arkansas recorded only 355, 753, and 114 free people of color respectively. The total for Louisiana was 18,647. Joseph Logsdon and Caryn Cossé Bell, "The Americanization of Black New Orleans," In Creole New Orleans: Race and Americanization, Arnold R. Hirsch and Joseph Logsdon, ed. (Baton Rouge: Louisiana State University Press, 1992), 206, 209.
} 
territory which was chronically undermanned. ${ }^{15}$ French and Spanish slave codes contained mechanisms which allowed some slaves to purchase their own freedom, and this in addition to the general lack of available women for the workers and soldiers of the colony, led to the establishment of a class of mixed race, French speaking free people of color. In the first decades of the colony, pragmatic Capuchin friars, who represented the Church in Louisiana, slowly began to endorse mixed race marriages and baptisms, a practice Spanish Capuchins would largely put to an end. ${ }^{16}$

While the temporary drafting of free people of color, or in some cases slaves, into local militias to fight Native Americans or recapture runaway slaves was certainly not unheard of in the early days of many North American colonies, the vast wilderness under the jurisdiction of the fledgling colony of Louisiana and the unavailability of French and, later, Spanish soldiers led to a surprising reliance on black militiamen. ${ }^{17}$ The Spanish colonial government especially found the benefits of allowing free people of color to keep arms to be well worth the possible risks. The Natchez War of 1730 saw the establishment of a permanent black militia, which the Spanish would divide into darker skinned and lighter skinned divisions. ${ }^{18}$ The officers in charge of these units were themselves free black Creoles and the position was seen as a mark of pride and key to personal success in the local community. ${ }^{19}$ While arming free people of color in a slave society was certainly a risk, the French and Spanish gambled that the black Creoles

\footnotetext{
${ }^{15}$ Usner, Daniel Jr., Indians, Settlers, and Slaves in a Frontier Exchange Economy: The Lower Mississippi Valley Before 1783. (Chapel Hill: University of North Carolina Press, 1992), 79.

${ }^{16}$ Caryn Cossé. Bell, Revolution, Romanticism, and the Afro-Creole Protest Tradition in Louisiana: 17181868. (Baton Rouge: Louisiana State University Press, 1997) 15.

${ }^{17}$ Usner, Indians, Settlers, \& Slaves in a Frontier Exchange Economy, 86.

${ }_{18}^{18}$ Bell, Revolution, Romanticism, and the Afro-Creole Protest Tradition, 16.

${ }^{19}$ Ibid.
} 
would be less likely to become involved in slave uprisings if they were allowed a stake in the responsibilities of the government.

Service in militias gave members of the black Creole community a sense of civic virtue and participation which would define their later claim to social and political equality in a republican society. At that same time, a slave revolt in Saint Domingue which would evolve into the Haitian Revolution stirred fears of a similar uprising in Louisiana, where white radicals such as Joseph Bouyavel were spreading the news of French Emancipation and the promises of the Declaration of the Rights of Man to slaves in rural Louisiana, and black Creole officers, such as Pierre Bailly, were accused of spreading revolutionary sentiment amongst the militia. ${ }^{20}$

The war in Saint Domingue and the eventual Haitian Revolution add a layer of complexity to the Creoles' adoption of the republican ideals of freedom and equality. Saint Domingue had a much larger and wealthier class of free black Creoles than Louisiana, and the role of this class as the bulk of the rural police force created antagonisms between free black Creoles and slaves on a scale that could not be matched in Louisiana. ${ }^{21}$ The Haitian Revolution prompted an exodus of thousands of white and black Creoles, many of whom would arrive in Louisiana after their initial escape to other Caribbean islands or the United States. In New Orleans, the immigration of so many Caribbean Creoles strengthened the city's connection to its French heritage, as New Orleans's demographics were tipped to a point where, by 1810 , there were 3,102 free

\footnotetext{
${ }^{20}$ Bell, Revolution, Romanticism, and the Afro-Creole Protest Tradition, 154.

${ }^{21}$ Ibid.: 43 .
} 
black Creoles, 2,731 whites, and 3,226 slaves. ${ }^{22}$ This influx of Creole immigrants reinvigorated the rivalries between the once again dominate francophone community and the growing Anglo-American section of New Orleans to such a degree that, in 1836, the city was partitioned into three semi-autonomous municipalities not united until 1852. ${ }^{23}$ The partition of city government, with two municipalities firmly under white Creole control, shielded New Orleans's black Creole community from the growing Anglo-American influence, in terms of American expectations in a bi-racial social order, by carrying Creole concepts of race and class further into nineteenth century without Anglo-American oversight.

Napoleon's attempts to reclaim the island in 1803 had again sent refugees to Louisiana, among them some disillusioned by the direction of the imperialistic French government. By 1811, these republican revolutionaries used New Orleans' white and black Creole population and the adjacent privateer enclave of Barataria as a recruiting ground for expeditions in support of the Mexican and Columbian wars for independence. ${ }^{24}$ The Americans, who had abolished the black militias after the

${ }^{22}$ Bell, Revolution, Romanticism, and the Afro-Creole Protest Tradition, 37.

Also: Paul F. LaChance, "The 1809 Immigration of Saint-Domingue Refugees to New Orleans: Reception, Integration and Impact" Louisiana History 29, No. 2 (Spring,1988): 117.

${ }^{23}$ Dennis C. Rousey, Policing the Southern City: New Orleans, 1805-1889 (Baton Rouge: Louisiana State University Press, 2001), 37, 41.

${ }^{24}$ Bell, Revolution, Romanticism, and the Afro-Creole Protest Tradition, 46.

The role of the Creole brothers Lafitte in supporting the Republic of Cartagena in Columbia and the American War of 1812 is overly romanticized. While the Lafittes had ties to the black Creole community through Pierre's black Creole wife, they profited greatly from the illegal importation of slaves. Jean Joseph Amable Humbert and Renato Beluche provide the best examples of popular republican corsairs outfitting in Louisiana, who used Barataria not only to recruit black Creoles, but also to illegally immigrate to the United States to begin their operations. While historians find it difficult to prove if either Lafitte was present at the Battle of New Orleans, Humbert was personally commended by General Jackson for his service, and black Creoles served both in an official regiment as well as with the Baratarians. See William C. Davis The Pirates Laffite: The Treacherous World of the Corsairs of the Gulf (Orlando: Harcourt, Inc., 2005). 
Louisiana Purchase, soon found themselves in the same situation the French and Spanish had faced under threats of hostile Native Americans and slave revolts, when in 1814 the British threatened to invade. Desperate to avoid the supposed risk of the large population of black Creoles supporting the British, General Andrew Jackson embraced black Creoles not only with the creation of black units (under white officers) but also with a call to arms emphasizing their share in American society, surprisingly addressing them as citizens. ${ }^{25}$

Free people of color had again benefitted from a lack of adequate manpower in the region and performed some of the duties of citizenship (the black Creole community took great pride in fielding soldiers at the Battle of New Orleans into the late nineteenth century), but this victory was short lived; after their victory over the British, the American government and white citizens again restricted the civic responsibilities and status of black Creoles.

Creole elites interested in republican ideas began joining the Freemasons and forming new lodges in the 1790s. As the Creoles were increasingly alienated from Church affairs, first with the takeover of Church hierarchy by the Baltimore-based American Roman Catholic Church in 1805, and later in the 1840s when Irish immigrants began to exert an influence, the Creole elite sought intellectual and social pursuits in secular organizations such as the Freemasons. ${ }^{26}$ New Orleans republicans also remembered, in their frustrations with Church hierarchy, that the Catholic Church had

\footnotetext{
${ }^{25}$ Bell, Revolution, Romanticism, and the Afro-Creole Protest Tradition, 53.

${ }^{26}$ Michael Doorly, "Irish Catholics and French Creoles: Ethnic Struggles within the Catholic Church in New Orleans, 1835-1920," The Catholic Historical Review 87, No. 1 (2001): 39.
} 
opposed the French Republic, inspiring greater anti-clerical sentiment in the city. ${ }^{27}$ While the majority of American Freemason lodges identified themselves with a Jeffersonian brand of republicanism, New Orleans lodges remained aligned with the more socialistic and egalitarian French lodges. ${ }^{28}$

When the Freemasons' reputation for religious tolerance caused a scandal in the 1840s, New Orleans lodges came together to publish a journal describing their beliefs called Le Franc-Maçon. ${ }^{29}$ While the journal may have been founded to quell fears that the Freemasons were a radical organization, New Orleans Freemasons were soon inspired to pursue a decidedly more radical bent. They began publishing articles written and later inspired by the French thinker Abbé Grégoire which proposed not only a model republic based on virtue, but also the secularization of society necessary for such a republic to exist. ${ }^{30}$ Radical New Orleanians embraced Grégoire's calls to replace hierarchical religion with the tolerance, equality, and ritual of Freemasonry. The Revolution of 1848 similarly energized Creole republicans, who attended in large numbers the celebratory events organized mainly by local Freemasons. ${ }^{31}$

The membership of a secret society is difficult to trace, and while New Orleans Freemasons were likely to be mostly liberal white Creoles, they did provide an important influence on the black Creole community. The mixing of white and black Creoles in Masonic lodges can be traced to 1820, when Pierre Roup, a well connected mixed-race immigrant from Saint Domingue, was a leader in the establishment of the

\footnotetext{
${ }^{27}$ Bell, Revolution, Romanticism, and the Afro-Creole Protest Tradition, 147.

${ }^{28}$ Bell, Revolution, Romanticism, and the Afro-Creole Protest Tradition, 155.

${ }^{29}$ Ibid.: 152.

${ }^{30}$ Ibid.: 156.

${ }^{31}$ Ibid.: 161.
} 
Perseverance lodge. ${ }^{32}$ Black Creole historian Charles Rousséve wrote in 1937 that many free black Creoles joined the Freemasons before the Civil War, when abolitionist Freemasons in New Orleans passed a resolution to admit black members "on terms of absolute equality and brotherhood."33 Another account by a white Creole freemason mentions two black Creoles as members of his lodge in $1867 .{ }^{34}$ The radical ideologies adopted by New Orleans Freemasons certainly made an impact on the black Creole elite in the city. Evidence suggests that racially integrated lodges survived in the city until 1895, when increasing pressure from Jim Crow legislation finally segregated not only Masonic lodges, but also churches and the French Opera House. ${ }^{35}$

Socially, the black Creoles occupied a precarious place in the city's ethnic and racial hierarchy throughout the nineteenth century. Mostly educated and involved in what can be considered middle-class trades and businesses, black Creoles were defined by a Louisiana state supreme court ruling in 1856 which held that free people of color were as different from slaves as whites. ${ }^{36}$ Free black Creoles in Antebellum Louisiana could own property, make contracts, and even testify against whites in court, but they lacked crucial political rights and were in danger of slipping to the bottom of America's bi-racial class system.

At the outbreak of the Civil War nearly 3,000 free black Creoles enlisted in the Confederate Army, arguably to secure their tenuous position in case secession was a

\footnotetext{
${ }^{32}$ Bell, Revolution, Romanticism, and the Afro-Creole Protest Tradition, 182.

${ }^{33}$ Ibid.

${ }^{34}$ Ibid.

${ }^{35}$ Tregle and Bell, "The Americanization of Black New Orleans," Creole New Orleans: Race and Americanization, 259.

${ }^{36}$ Tunnell, Crucible of Reconstruction, 67.
} 
success. ${ }^{37}$ When New Orleans fell to Union forces in 1862, these black Creole soldiers, along with thousands of runaway and recently freed African American slaves, joined the federal army; by 1864 over 24,000 black Louisianans were enlisted. ${ }^{38}$ When L'Union, a radical French language paper intended for the black Creole community, was launched shortly after the federal takeover, it immediately encouraged enlistment in the Union Army, proclaiming it "an honor understood by our fathers who fought on the plains of Chalmette," site of the Battle of New Orleans. "He who defends his fatherland is the real citizen ..." the newspaper declared. ${ }^{39}$ Service in Louisiana's Native Guard became a galvanizing, as well as a radicalizing, experience for New Orleans' black Creoles. Friendships were formed that would continue into politics and the legislature during Reconstruction, and while the hint of change in the air prompted many black Louisianans to serve, Francis E. Dumas, a black Creole and one of only two black majors in the Civil War, urged his slaves to join as well. ${ }^{40}$

Union occupation in rural parishes initially provided the chance for escape from slavery, though in the Emancipation Proclamation, issued January 1, 1863, the thirteen parishes under Union control were exempted and slavery continued in the region until the close of the war. ${ }^{41}$ This prompted many of the early runaway slaves to seek better social and economic circumstances in New Orleans, leading to potential class antagonisms with the black Creole community.

\footnotetext{
${ }^{37}$ Tunnell, Crucible of Reconstruction, 70.

${ }^{38}$ Rebecca J. Scott, Degrees of Freedom: Louisiana and Cuba After Slavery (Cambridge, MA: The Belknap Press of Harvard University Press, 2005), 35.

${ }^{39}$ Quoted from: Tunnell, Crucible of Reconstruction, 71.

${ }^{40}$ James G. Hollandsworth Jr. The Louisiana Native Guards: The Black Experience During the Civil War (Baton Rouge: Louisiana State University Press, 1995), 108-110.

${ }^{41}$ Scott, Degrees of Freedom, 31.
} 
After the war, federal occupation and Emancipation prompted mass immigration of African Americans, mainly newly freed slaves, into the city. ${ }^{42}$ Between 1860 and 1870, the total black population of New Orleans roughly doubled. ${ }^{43}$ These immigrants settled in the mostly undeveloped, undesirable areas of the city's geography. The area known as "back-of-town" received the greatest number of freed slaves, who built up neighborhoods in an area that Richard Campanella describes as being "high risk," due to the poor drainage and increased threat of mosquito-borne disease, and inconvenient, being further from the commercial core and the affluent neighborhoods which flanked it. ${ }^{44}$ Back-of-town did offer its inhabitants some advantages, however, as it provided the cheapest housing in the city and was conveniently located to new infrastructure projects such as canals and railroads, which offered unskilled employment as the city spread north toward the lake. ${ }^{45}$ With the majority of African Americans settling here, the old uptown/downtown, or Anglo/Franco, rivalry was continued within the black population, as black Creoles remained centered in their traditional downtown neighborhoods and bastions of French ethnic identity. ${ }^{46}$

Despite their apparent similarities according to the American bi-racial system, African Americans and black Creoles were at odds with each other culturally,

\footnotetext{
${ }^{42}$ Also referred to as Anglo-Africans, emphasizing their language and religious affiliation, this paper will use the more broad term African American to denote Anglo-American cultural influence.

${ }^{43}$ Richard Campanella, “An Ethnic Geography of New Orleans," Journal of American History 94, No. 3 (December 2007): 708.

${ }^{44}$ Campanella, "An Ethnic Geography of New Orleans," 706.

${ }^{45}$ Ibid.

${ }^{46}$ The uptown/downtown divide was established just before the Louisiana Purchase when Americans began settling in Faubourg St. Marie, later the Second Municipality, on the upriver side of Canal Street. Canal Street remains the barrier between uptown and downtown, which serve as relative terms to describe the location of a neighborhood and, until recently, the heritage of its inhabitants. White flight, middle class black flight, and gentrification have eroded some of the importance of neighborhoods in determining heritage, but some neighborhoods retain much of their original ethnic makeup, such as Faubourg Treme, St. Joseph, St. Roch, and Broadmoor.
} 
spiritually, and politically for much of the nineteenth century. Under Union occupation, military officials worked closely with Northern churches in resettling runaway and freed slaves within the city. ${ }^{47}$ Many Protestants of the time, especially the Evangelical community, both white and black, involved in black churches held much disdain for the Catholic faith practiced by the Creoles. The spiritual divisions between African Americans and black Creoles serve as an important way to understand how and why they were divided politically. African Americans predominately worshiped in black-only churches, which formed the basis of their semi-autonomous community. Black Creoles, however, had long strived for social and political equality, and "resented" the voluntary racial segregation, in part promoted by Northern philantropists, taking place in African American churches, mutual aid societies, and schools. ${ }^{48}$ African Americans tended to accept the bi-racial system and worked around it through their autonomous institutions, unlike the black Creoles, whose position within the multi-tiered racial system was becoming tenuous as they fought for equality in a changing society.

In 1863, Jean-Charles Houzeau, a Belgian radical who arrived in New Orleans after a stint smuggling Union sympathizers out of Confederate Texas, began work as a correspondent for L'Union. After L'Union folded, Houzeau was brought on to Paul Trévigne's New Orleans Tribune, the country’s first black daily newspaper. ${ }^{49}$ Houzeau enjoyed the anonymity that his dark complexion afforded him in New Orleans, often passing for black Creole in public, but he was keen to keep his outsider status at the

\footnotetext{
${ }^{47}$ Logsdon and Bell. "The Americanization of Black New Orleans: 1850-1900," In Creole New Orleans: Race and Americanization, 236.

48 Ibid.

49 Jean-Charles Houzeau, My Passage at the New Orleans Tribune: A Memoir of the Civil War Era, ed. David C. Rankin (Baton Rouge: Louisiana State University Press, 1984): 23.
} 
paper, even as he took over as editor. ${ }^{50}$ Charged with expanding both the English and French editions of the Tribune, Houzeau began to realize that support from the black Creole and European communities could only take the cause of equality so far. ${ }^{51}$ Houzeau was frustrated by the multi-lingual office of his paper, with its inevitable complications of culture and class, and blamed the disunity of the general black population on fact that the black Creoles' pride led them to resent white, often Northernborn and more moderate, Republican leaders. ${ }^{52}$ With this perspective, however, Houzeau would be caught in the main fracture which separated the political aspirations of black Creoles and African Americans. While Northern liberals were of great and essential help to the recently freed African Americans, their gradualist politics and racial ideology were judged too conservative by black Creoles to assist in the reforms they thought vital. $^{53}$

The 1866 New Orleans Race Riot which followed a largely black Republican, and black Creole, attempt to convene a new state constitutional convention served to the black population of Louisiana as a reminder that federal protection was a necessity for the transition of government following the Civil War. While the Tribune and Louisiana Republicans organized themselves to pursue a new Constitution under greater federal protection in 1868, the relationship between black Creoles and the recently freed African Americans flocking to the city remained an uneasy one. Black Creoles relied on their

\footnotetext{
${ }^{50}$ Houzeau, My Passage at the New Orleans Tribune, David C. Rankin, ed., 24.

${ }^{51}$ Among the French subscribers to the New Orleans Tribune was Victor Hugo, who along with others, contributed to organizations supported by the newspaper. Despite appeals to white Republican congressmen and African American clergymen, the English edition had difficulty finding an audience for its unequivocal calls for racial equality. Ibid.: 33.

${ }^{52}$ Logsdon and Bell, "The Americanization of Black New Orleans," In Creole New Orleans: Race and Americanization, 237.

${ }^{53}$ Ibid.
} 
economic status and crucial station in various historical crises to argue for equality under the law, yet the largely uneducated and unskilled freedmen were kept at a distance ${ }^{54}$ One scholar describes the black Creole approach to dealing with African Americans as paternalistic, and in the same vein as Northern missionaries and philanthropists who sought to uplift the conditions of former slaves without necessarily viewing them as equals. One issue was the two groups' divergent experience of history; the black Creoles were imbued with a revolutionary heritage and lineage of increasing status, while recently freed African Americans, who had been denied freedom for generations, were more cynical, or in the words of black Creole activist Rodolphe Desdunes, doubting. ${ }^{55}$

The 1868 constitutional convention, nonetheless, was Louisiana's first to include a Bill of Rights, which guaranteed every citizen, regardless of race or color, "equal rights and privileges" in licensed business, "public resort," and public transportation. ${ }^{56}$ What was essential to the document was the radical inclusion of what delegates termed public rights; more intangible than civil or political rights, but nearly as important in securing social equality. ${ }^{57}$ This vague concept of rights would have arguably prevented the growing trend of social segregation in the late nineteenth century and its demoralizing yet intangible effects. Its phrasing was a product of revolutionary France,

\footnotetext{
${ }^{54}$ A biographical survey prepared by David Connell Rankin lists a variety of information for 172 black leaders in New Orleans during Reconstruction; of which five were veterans of the Battle of New Orleans and only three were enslaved before Emancipation. The vast majority are free black Creoles of mixed-race employed in skilled crafts or owning businesses. See: David Connell Rankin, "The Forgotten People: Free People of Color in New Orleans, 1850-1870," (PhD diss., Johns Hopkins University, 1976), 300-307: Table A-7.

${ }^{55}$ Shirley Elizabeth Thompson, Exiles at Home: The Struggle to Become American in Creole New Orleans (Cambridge, MA: Harvard University Press, 2009), 236, 237.

${ }^{56}$ Hollandsworth, An Absolute Massacre, 117.

${ }^{57}$ Ibid.: 123.
} 
first discussed in the 1830 s as a way to rectify the failings of earlier revolutionary phases in achieving total equality. ${ }^{58}$ In contrast, conservative delegates argued, in language eerily similar to that of the US Supreme Court's holding in Plessy v. Ferguson, that social norms and expectations could not be legislated. ${ }^{59}$

The broad, universal, and inclusive rights language was also opposed by conservatives who saw it as either a platform for government intrusion into private lives or as merely irreconcilable with their concept of society. ${ }^{60}$ Conservative delegates also argued that many of the provisions in the state Bill of Rights were redundant, as they were already stipulated by the Thirteenth Amendment to the Constitution and the 1866 Civil Rights Act. ${ }^{61}$ While this argument won at the time of the debate, the Supreme Court's narrowing definition of the state's role in discrimination would make these federal provisions difficult to enforce in the future. The constitution was ratified in April, 1868, thanks in large part to General Philip Sheridan's success in registering large numbers of black voters, but also through the disenfranchisement of many reactionary ex-Confederates. ${ }^{62}$ Though the civil rights protections of the 1868 Constitution would eventually be undone in the following decades by such Confederate veterans, a black

\footnotetext{
${ }^{58}$ Rebecca J. Scott, "Public Rights, Social Equality, and the Conceptual Roots of the Plessy Challenge," Michigan Law Review, 106 (March 2008): 785.

The term can be traced to Article 6 of the Declaration of the Rights of Man and Citizen, which stated that all citizens were equally eligible for "public honors." The specific phrase "public rights" was coined by the Italian republican Pellegrino Rossi in the 1830s. Radical Creoles in New Orleans were closely connected to the revolution in France, in part because of New Orleans's connection to the Haitian Revolution, and the fact that many Creoles were educated in Paris. For example, Dr. Louis Charles Roundanez, a black Creole who financed the radical New Orleans Tribune, participated in the 1848 Revolution while studying medicine in Paris. For more information, see the above article and the relevant sections of: Bell, Revolution, Romanticism, and the Afro-Creole Protest Tradition in Louisiana.

${ }^{59}$ Tunnell, Crucible of Reconstruction, 119.

${ }^{60}$ Scott, Degrees of Freedom: 44.

${ }^{61}$ Tunnell, Crucible of Reconstruction: 124.

${ }^{62}$ Ibid.: 134.
} 
Creole representative from a sugar parish had proposed, unsuccessfully, an interesting safeguard: that no legislative body could amend this constitution or call another convention for a period of seventy years. ${ }^{63}$ Regardless, the contemporary success of the 1868 state constitution in enshrining civil rights was hailed at the time as a great victory. Oscar J. Dunn, the newly elected black Lieutenant Governor of Louisiana, pronounced after its passage that it exhibited a "progress more rapid than that of the Northern States, East, or West," and that he looked forward to a day when, "throughout this land intelligence will be respected, whatever the color of skin." ${ }^{64}$

With civil rights protections enshrined in the state constitution, African American and black Creole activists relied on such legislation to initiate boycotts and lawsuits against egregious discriminators. ${ }^{65}$ Lawsuits were brought forward by activists to rectify social indignities such as denied services and accommodations and the intentional salting of drinks in saloons and restaurants. Fourteen businesses were sued for discrimination in the first five years of Louisiana's 1868 Constitution and 1869 Civil Rights Act, resulting in fines and damages as high as one thousand dollars per plaintiff. ${ }^{66}$ Especially important was the struggle to end segregation on the city's streetcar lines. Before the Civil War, free people of color were restricted from riding all but the "star" cars, which ideally made up a third of the fleet, but could become white-only if the lines were busy. ${ }^{67}$ Under occupation and Reconstruction, black leaders had pressured military

\footnotetext{
${ }^{63} \mathrm{Scott}$, Degrees of Freedom: 46.

64 "Remarks of Lt. Gov. Dunn," July 13, 1868, Folder 77/11, Alexander Pierre Tureaud Papers (18591972) Box\#77, Amistad Research Center, Tulane University.

${ }^{65}$ John W. Blassingame, Black New Orleans: 1860-1880 (Chicago: University of Chicago Press, 1973), 185.

${ }^{66}$ Ibid.: 187.

${ }^{67}$ Ibid.: 189.
} 
commanders to end segregation on streetcars. When federal forces withdrew, black newspapers, such as the New Orleans Tribune, encouraged readers to engage in civil disobedience by boarding white cars, a strategy which was ultimately successful. ${ }^{68}$ After the liberal 1868 state constitution, the debates over Louisiana state civil rights law paralleled national debates in the role of government in effecting social change. Intimidation and assassination of black Republican leaders by white reactionary organizations had led to the election of a more moderate government in $1869 .{ }^{69}$ Newly elected Governor Henry Clay Warmoth, a Northern-born Republican who moved to New Orleans during Union occupation, sought to make real the gains of Reconstruction while pragmatically bringing Louisiana into order and out of debt. Warmoth attempted to strike a tenuous compromise between radicals and moderates by arguing against additional civil rights legislation brought forward by radical Republicans to reinforce the protections of the 1868 constitution, stating that it would be better for laws to lag behind social expectations and opinions than outrun them.$^{70}$ Warmoth vetoed a bill to enforce integration on public transportation in early 1869 before allowing a second Civil Rights Act passed by the legislature to become law. When the legislature attempted again to pass more comprehensive legislation barring discrimination, Warmoth delayed action on the bill until after the next party convention, vetoing it in $1871 .{ }^{71}$ Warmoth's lukewarm support of real protections for civil rights, and his support by New Orleans' black

\footnotetext{
${ }^{68}$ Blassingame, Black New Orleans: 1860-1880, 189.

${ }^{69}$ Tunnell, Crucible of Reconstruction, 155.

${ }^{70}$ Ibid.: 167.

${ }^{71}$ Ibid.: 169.
} 
Republican leadership, created a crisis within the Republican Party of New Orleans which would slow the passage of additional civil rights protections.

The legislative protections against discrimination passed during the Reconstruction era did not fare well when examined by the Supreme Court. Louisiana's 1869 Civil Rights Act was relied upon by Josephine DeCuir in her suit against a steamboat company which denied her accommodations in a "white only" compartment of a ship in $1872 .{ }^{72}$ DeCuir was a black Creole plantation owner who booked passage on a steamboat from New Orleans to her estate up the Mississippi River in Pointe Coupeé. Her brief for the Louisiana State Supreme Court contains an argument telling of the black Creole perspective:

[DeCuir] alleges that she is well educated, resided in Paris, France, several years, and that the treatment above mentioned is not only a gross infraction of her rights under the constitution and laws of the United States and of this State, but was also an indignity to her personally, which shocked her feelings and caused her mental pain, shame and mortification. She prays for $\$ 25,000$ actual damages and $\$ 50,000$ exemplary damages. ${ }^{73}$

In the Tribune, and later in the New Orleans Crusader and the Plessy case, black Creoles consistently used language insisting not only on their constitutional rights but also that the indignities of segregation stood in direct opposition to both social and political equality, especially where economic class was concerned. This rhetoric had been central to the discussion of public rights in the 1868 convention and in the passage of the 1869 Civil Rights Act. DeCuir was independent, the owner of her late husband's

\footnotetext{
${ }^{72}$ Joseph R. Palmore, “The Not-So-Strange Career of Interstate Jim Crow: Race, Transportation, and the Dormant Commerce Clause," Virginia Law Review 83 No.8 (November 1997): 1777.

${ }^{73}$ Decuir v. Benson, 27 La. Ann. 1, 1875 WL 263, No. 4829, page 1.
} 
estate, and educated, indicative of her higher economic standing, but her brief also appealed to the Victorian sentiments of the justices by emphasizing the shame and mortification experienced by a respectable woman. Her suit was upheld by the state supreme court, which declared, "It is settled, in this State at least, that colored persons now have all the civil and political rights which white persons enjoy."74

In the steamship company's appeal to the U.S. Supreme Court, the steamer's captain, John Benson, argued that since he provided service to both Louisiana and Mississippi, and Mississippi clientele expected segregated cabins, Louisiana’s Civil Rights Act imposed upon his ability to provide interstate transportation. Noting that DeCuir had booked passage between two points within the state, both the trial and Louisiana state supreme court agreed that the segregated accommodations had violated DeCuir's civil rights under the statute which protected her from discrimination "within the state of Louisiana." 75 The case moved up to the U.S. Supreme Court at a time when it was grappling with the limits of not only civil rights legislation but also the scope of the Commerce Clause of the Constitution. Chief Justice Morrison Waite seized a geographic complication in the Louisiana court's holding, that a Louisiana law was to be enforced on steamers accepting and depositing passengers on both sides of a river which (though much further) upstream became an interstate boundary, to strike down the Civil Rights Act as a "direct” burden on interstate commerce. ${ }^{76}$ Waite's holding went on to imply that any state law impeding the "uniformity" of laws across state lines concerning transportation and accommodations could constitute such a burden.

\footnotetext{
${ }^{74}$ Decuir v. Benson, 27 La. Ann. 1, 1875 WL 263, No. 4829, page 1.

75 Palmore, "The Not-So-Strange Career of Interstate Jim Crow," 1778.

${ }^{76}$ Ibid.: 1781.
} 
While white elites formed a more inward focused society during this period, working-class whites and blacks achieved surprising social equilibriums. The classically integrated residential patterns of New Orleans continued, placing white and black families in close proximity to each other in dense Uptown and Downtown neighborhoods. Added to this mix were New Orleans' many immigrant communities, which were also integrated into various residential areas. Germans and Italians became increasingly prevalent in the Creole neighborhoods of the French Quarter and Faubourg Marigny, while Eastern European immigrants, Jewish immigrants, the city's Irish and African American populations were more likely to be concentrated in Uptown workingand middle-class neighborhoods. ${ }^{77}$ While New Orleans's neighborhoods often were home to a wide variety of ethnic groups, the geographic proximity of races and ethnicities that integrated neighborhoods fostered promoted tolerance on a day-to-day basis but did not guarantee social equality in leisure time, work, or education.

Integration in New Orleans's school system had reached some extraordinary milestones without being particularly long lasting. Though many families in this largely Catholic city sent their children to parochial schools, which remained segregated throughout the period, New Orleans's experiment with integrated public education resulted in the desegregation of more than a third of the city's schools. Beginning in 1870 , a court decision prompted a gradual desegregation process that simply required schools to admit any new applicants regardless of race. This allowed parents to continue

\footnotetext{
${ }^{77}$ Campanella, “An Ethnic Geography of New Orleans," 708.
} 
to determine the racial makeup of the schools in which their children enrolled. ${ }^{78}$ Public school integration was most successful in the Downtown, Creole neighborhoods below Canal Street, where the five integrated schools with the highest enrollments for black students were located. ${ }^{79}$ School integration remained, of course, a point of contention for the city's growing White League. ${ }^{80}$

In December, 1874, members of the White League had attempted to forcefully re-segregate an all girls' school in the French Quarter. They were unsuccessful in this venture, however, as the complicated racial makeup of black Creoles made it nearly impossible to tell fair-skinned blacks from whites; the girls, of course, limited the amount of information they were willing to give about the makeup of their families. ${ }^{81}$ Public education was of principle importance to recently freed African Americans. With greater access to education throughout the 1870s in New Orleans, families which relocated to the city gradually benefitted in the form of increased literacy, while the rural literacy rate among African Americans remained dismally low into the twentieth century. ${ }^{82}$ Overall, the relative lack of access to public education for African Americans uptown of Canal Street and the steady migration of uneducated, rural blacks to the city contributed to high rates of illiteracy which left the voting rights of African Americans

\footnotetext{
${ }^{78}$ Louis R. Harlan, "Desegregation in New Orleans Public Schools During Reconstruction," In African American Life in the Post-Emancipation South, 1861-1900. Ed. Donald G. Nieman (New York: Garland, 1994), 665.

${ }^{79}$ Harlan, "Desegregation in New Orleans Public Schools During Reconstruction," 667.

${ }^{80}$ The White League, its membership, organization, and influence, will be addressed more conclusively in the following chapter.

${ }^{81}$ James G. Gill, Lords of Misrule: Mardi Gras and the Politics of Race in New Orleans (Jackson: University Press of Mississippi, 1997), 119, and George Washington Cable, “The 'Haunted House' in Royal Street," Strange True Stories of Louisiana (Gretna, LA: Pelican Publishing, 1994), 224.

${ }^{82}$ Burton W. Peretti, The Creation of Jazz: Race, Music, and Culture in Urban America (Urbana: University of Illinois Press, 1994), 23.
} 
vulnerable (this was especially true in rural parishes). Louisiana's brief experiment with integrated public education ended with the passage of the 1879 Constitution, which omitted the 1868 Constitution's civil rights protections.

The Democratic Party was able to consolidate a series of political victories after the Battle of Liberty Place in 1874, convening a new constitutional convention after control of the state legislature was achieved. The 1879 Constitution, with its critical omission of civil rights protections, and the nullification of the 1869 Civil Rights Act in Benson v. Decuir, temporarily frustrated the abilities of civil rights activists to bring forward successful test cases. However, the civil rights movement was reinvigorated in the 1880s by Rodolphe Desdunes and the New Orleans Crusader. Desdunes was a black Creole and Straight University graduate who was inspired not only by the radical black Creole leaders of the 1868 Constitutional Convention but also by the French Revolution of $1848{ }^{83}$ Throughout his career, he found strong connections and parallels between the civil rights movement in Louisiana and French Revolutionary ideals, an association perhaps fostered by his membership in an integrated Creole Masonic lodge. He had been angered by the lack of organized protest by the black community in the wake of the Battle of Liberty Place and entered New Orleans politics in 1878 by forming the Young Men's Progressive Organization to demand equal social and political rights. In 1887, Desdunes formed L'Union Louisianaise, a radical organization founded with the goal of establishing a radical, French language newspaper. Through this organization and a

\footnotetext{
${ }^{83}$ While the author is unsure of Rodolphe Desdunes capacity in the Battle of Liberty Place (though he was a long-time employee of the custom house), it is possible that he was wounded during the fighting that day. See: "The Casualties in Monday's Conflict," The New York Times September 16, 1874: 1, ProQuest Historical Newspapers, The New York Times (1851-2008); and "Now for a Test Case," The New York Times, February 26, 1892: 9, ProQuest Historical Newspapers, New York Times (1851-2008).
} 
partnership with Louis Martinet, a black Creole politician who had been radicalized after having supported the passage of the 1879 Constitution, Desdunes was able to establish the Crusader in 1894, which allied itself with radical black Republicans and integrated unions. When it began publication, the Crusader was the only black daily newspaper in the country. ${ }^{84}$

With Democrats in power for over two decades, the intensification of discriminatory legislation, which began in 1890, presented activists with blatant violations of the protections of the Fourteenth and Fifteenth Amendments. That year Desdunes gathered black and white leaders from across the South in Washington, D.C. to form the American Citizens Equal Rights Association for the purpose of testing the constitutionality of discriminatory laws passed by reactionary Democrats. Shortly after formation, however, Protestant African American leaders began to shy away from the direct action proposed by the New Orleans faction. ${ }^{85}$ The black Creole call to "secure the free and full exercise of every political and civil right as guaranteed to the American citizen," as well as their strategy of bringing forth test cases in courts, stood in contrast to the isolationist policies endorsed by black Methodist leaders. ${ }^{86}$ The burden of funding the legal challenges as well as orchestrating their execution increasingly fell almost solely on New Orleans-based black Creoles.

\footnotetext{
${ }^{84}$ Logsdon and Bell, “The Americanization of Black New Orleans, 1850-1900,” In Creole New Orleans: Race and Americanization, 254-256.

${ }^{85}$ Ibid.: 257.

86 "Constitution of the American Citizens Equal Rights Association," The Crusader (New Orleans) Vol. 2 No. 6 (March 22, 1890):1, In Charles B. Rousseve Collection, 1902-1993 Papers, 1836-1993, Amistad Research Center, Tulane University.
} 
In reaction to the dissolution of the American Citizens Equal Rights Association's and to reflect the black Creole character of its primary backers, Desdunes organized New Orleans black Creoles, who had provided most of the funding for the association, into the Comité des Citoyens, or Citizens Committee, in 1891. In 1890, the Louisiana legislature had passed the Separate Car Law, officially mandating segregation in railroad travel. The repeal of the Separate Car Law became a major facet of the committee's agenda, while the group also pursued cases against the disenfranchisement of blacks from jury pools, literacy tests for voters, and anti-miscegenation laws. ${ }^{87}$ To head up the organization's legal team, the committee selected Albion Tourgée as their counsel; immediately after the Separate Car Law was enacted he had written an editorial for a Chicago paper calling for resistance to it. ${ }^{88}$ At the outset Tourgée served as an advisor to Louis Martinet and the black Creole philantropist Paul Bonseigneur as they selected test cases and prepared the committee's arguments, but his role as lead counsel would be crucial to the progress of the committee's cases. ${ }^{89}$

Act Number 111, the Separate Car Law, was an extremely important rallying point for black Creole activists who remembered the 1868 debate over public rights. The act had been slow in coming to Louisiana, to the point where conservative whites openly lamented the fact that the state had fallen behind the rest of the South in the push to

\footnotetext{
${ }^{87}$ Logsdon and Bell, “The Americanization of Black New Orleans, 1850-1900,” In Creole New Orleans: Race and Americanization, 258.

${ }^{88}$ Mark Elliott, "Race, Color Blindness, and the Democratic Public: Albion W. Tourgée's Radical Principles in Plessy v. Ferguson," The Journal of Southern History 67 No. 2 (May 2001): 289.

${ }^{89}$ Charles A. Lofgren, The Plessy Case: A Legal Interpretation (New York: Oxford University Press, 1987), 30-35.
} 
segregate public transport and facilities. ${ }^{90}$ In 1867 , the black community of New Orleans had successfully defeated segregation policies on public transit in the city by use of civil disobedience, but with the constitutional framework of segregation much better established, legal test cases were now the best hope for desegregation. ${ }^{91}$ To challenge this new law's constitutional merit, the Citizens Committee launched a two pronged attack on intrastate and interstate travel.

The first case began on February 24, 1892, when Desdunes' son Daniel was placed in a white passenger car with a ticket to Mobile, Alabama. Daniel Desdunes was likely chosen because his complexion would allow him to purchase a first class ticket without arousing suspicion before boarding the train. When Daniel Desdunes was arrested and charged, his defense immediately challenged the constitutionality of the law. The trial was scheduled to begin in late March, but was suspended until July after the presiding judge mysteriously vanished. Daniel Desdunes' defense, organized by Bonseigneur and the Citizens Committee and written by Tourgée, relied on the Interstate Commerce Clause in that he had booked passage on a railroad incorporated in Kentucky to a destination in Alabama, which by their interpretation of the clause was above state regulation as a strictly interstate business. ${ }^{92}$

With the assistance of Albion Tourgée, Desdunes' lawyers conspicuously omitted his intended destination of Mobile, Alabama, as to avoid falling into legal loopholes that lay between intra- and interstate commerce established by DeCuir and

\footnotetext{
${ }^{90}$ Otto H. Olsen, ed. The Thin Disguise: Turning Point in Negro History: Plessy v. Ferguson: A Documentary Presentation, 1864-1896 (New York: Humanities Press, 1967), 52, 53.

${ }^{91}$ Keith Wledon Medley, We as Freemen: Plessy v. Ferguson (Gretna, LA: Pelican Publishing, 2003 ), 79.

${ }^{92}$ State of Louisiana v. Daniel F. Desdunes, 18685 ( $2^{\text {nd }}$ Recorders Court, City of New Orleans, 1892); and Lofgren, The Plessy Case, 34.
} 
other more recent cases in Mississippi. ${ }^{93}$ When the trial resumed, the new judge, John $\mathrm{H}$. Ferguson, relied on a state supreme court decision issued during the recess which limited the Separate Car Law's scope to intrastate transportation only. ${ }^{94}$ Despite a less than dramatic outcome from the younger Desdunes' trial, the Citizens Committee as well as the Crusader looked toward the next prong of attack with great optimism; as Desdunes' decision was handed down an intrastate challenge was already moving up through the courts.

Homer Plessy was a black Creole artisan and Freemason who had been involved in the civil rights movement at least since 1887, when he served as vice president of a black Creole radical organization. ${ }^{95}$ Chosen for the case because of his light complexion (Plessy's paternal grandfather was a Frenchman who emigrated to New Orleans from Saint Domingue during the Haitian Revolution), Plessy boarded a train with a ticket to Covington, Louisiana, on June $7,1892 .{ }^{96}$ Plessy was arrested and charged, and the case began moving its way up through the court system. The committee lost at the state supreme court level, which quoted the Civil Rights Cases in striking down the argument that segregation violated the Thirteenth Amendment rights of blacks. ${ }^{97}$ Albion Tourgée was selected as lead counsel for the case before the U.S. Supreme Court, with Martinet and several others accompanying him. Tourgée was the originator of the term "colorblindness" in a legal context, and he hoped to persuade the Court that segregation

\footnotetext{
${ }^{93}$ Lofgren, The Plessy Case, 34.

${ }^{94}$ Louis A. Martinet, ed., The Violation of a Constitutional Right, (New Orleans: The Crusader Print, 1893): 1.

${ }_{95}^{95} \mathrm{Scott}$, Degrees of Freedom, 77.

${ }_{97}^{96}$ Medley, We As Freemen, 21.

${ }^{97}$ Ex parte Plessy, 45 La. Ann. 80, 11 So. 948.
} 
violated the Equal Protection clause of the Fourteenth Amendment because the law's intent was to serve the "gratification" of whites at the expense of blacks. ${ }^{98}$ The legal team behind the Plessy brief also included references to the intellectual legacy of the concept of public rights. They argued that laws arbitrarily separating society into races had the effect of creating a caste system, a system that would stand in direct opposition to the founding principles of the United States. ${ }^{99}$

The energy and optimism of the Citizens Committee was not shared by all black Creoles, much less by African Americans. In May 1893, Aristide Mary, who had provided the funding for the creation of the Citizens Committee, committed suicide shortly after confessing to his wife a fear of imminent assassination. ${ }^{100}$ Mary had long been a fixture among the black Creole elite, having been a supporter of the Catholic Indigent Orphans' Institute as a prominent free person of color before Emancipation. ${ }^{101}$ Along with Bonseigneur, Mary was one of the primary financial supporters of the Citizens Committee's legal battles, and reflected many of the same qualities of his fellow black Creole philanthropists; Mary had been educated in Paris much like Roundanez and Bonseigneur. The timing of his death suggests a profound connection to the strengthening of Jim Crow segregation and the dismal prospects for real equality in the near future; the New York Times noted in Mary's death notice that, "It is a singular

\footnotetext{
${ }^{98}$ Mark Elliott, "Race, Color Blindness, and the Democratic Public: Albion W. Tourgée's Radical Principles in Plessy v. Ferguson," The Journal of Southern History 67 No. 2 (May 2001): 291.

${ }^{99}$ Scott, "Public Rights, Social Equality, and the Conceptual Roots of the Plessy Case," 799.

100 “A Wealthy Negro's Suicide," New York Times, May 16, 1893: 8, ProQuest Historical Newspapers, the New York Times, 1851-2007 (accessed January 24, 2011).

${ }^{101}$ Rodolphe Lucian Desduens, Our People and Our History: Fifty Creole Portraits, trans. and ed. Sister Dorothea Olga McCants (Baton Rouge: Louisiana State University Press, 1973), 102.

The institute was a point of community pride for the black Creole elite as it symbolized their ability to better their own community through philanthropy rather than through seeking outside assistance.
} 
coincidence that many of the very wealthy colored men of this city have taken their own lives."102 Mary's will, which had been written in 1880, allotted one thousand dollars, "to be distributed among the poor, white and black."103

In New Orleans, the Crusader and the Citizens Committee continued to battle increasing segregation. In their native Downtown neighborhoods, black Creoles were protected by tradition from increasing racial and economic segregation in Uptown New Orleans, a protection they lost when travelling outside of their enclave. In May 1893 Paul Bonseigneur, a wealthy black Creole, purchased a summer home on the north shore of Lake Ponchartrain in hopes of improving the health of his ailing wife. Bonseigneur was informed that a committee of residents was being formed to forcibly remove him, though instead of an armed committee he eventually received a notice from local property owners that his presence "in our neighborhood and on the Beach will be highly disagreeable to us and to our families." ${ }^{104}$ As Bonseigneur moved his family back to New Orleans, the Citizens Committee was enraged that one of the most prominent and wealthy black Creoles, "esteemed and respected by all New Orleans," could not enjoy the privileges his fortune allowed. Calling attention to the slight against Bonseigneur was very much endemic of the Citizens Committee's perspective as an organization of the black Creole elite. Just as in DeCuir, at issue was Bonseignuer's inability to exercise the benefits of his economic station. Similarly, when the Seperate Car Bill had been before the senate in 1890, State Senator Henry Demas had voiced his opposition to it by

\footnotetext{
102 “A Wealthy Negro’s Suicide,” New York Times May 16, 1893: 8.

103 “Large Legacies,” Daily Picayune (New Orleans) May 18, 1893: 9.

${ }^{104}$ Louis A. Martinet, ed., The Violation of a Constitutional Right, (New Orleans: The Crusader Print, 1893): 6 .
} 
noting a flaw in its construction; "It places the entire Negro Race upon one common level and makes no distinction between the ignorant and the illiterate, and those who, by education, refinement, and culture, have raised themselves above the standard of their race." $" 105$

The Crusader organized a mass meeting that August to protest, and Tourgée contributed a letter for publication which continued the argument against segregation as a caste system. Tourgée called the "spirit of caste" the "most dangerous element of American civilization," before going on to contrast the concerted effort to demarcate a color line with the successful assimilation of immigrant groups who lacked the language, traditions, and religion of mainstream America. His argument intensified as he laid out the reason for segregation; to place incompetent and immoral whites above others for their own gratification; "How shall a white ignoramus continue to rank as a 'superior' if an educated Negro is regarded with respect! How shall a shiftless 'poorwhite' preserve his self-respect if a wealthy Negro is to be regarded as a creditable and desirable element of a community!"106 Despite Tourgée's accurate assessment of the social order in New Orleans, he was lacking in one regard: that the elite black Creole class had yet to reconcile its rift with the freedmen.

In 1896, however, the decision of the Supreme Court against Plessy and the Citizens Committee cemented the practice of legalized segregation. Searching for useful precedents in the case, the Court had relied mainly on cases dealing with school segregation such as Roberts v. City of Boston but also on cases involving transportation

105 "The Seperate Car Bill," The Crusader (New Orleans) July 19, 1890: 2.
${ }^{106}$ Martinet, ed., The Violation of a Constitutional Right, 19-20. 
such as Hall v. DeCuir and Louisville, New Orleans, and Texas Railroad v.

Mississippi. ${ }^{107}$ The Court was further influenced in its opinion by the Slaughterhouse

Cases and U.S. v. Cruikshank, both of which had originated in Louisiana and severely

limited the ability of the Fourteenth Amendment to influence the actions of state

governments. ${ }^{108}$ Tourgée had attempted to use the Thirteenth Amendment in his

argument against segregation, which was famously countered in Justice Brown's

holding that this badge of inferiority was assumed "solely because the colored race

chooses to put that construction upon it.",109

The loss of the Plessy case delivered a crippling blow to an organization and

community which was already fighting the most uphill of battles. Disheartened funders

prompted the disassembling of Citizens Committee, as anxiety and gloom became the

dominant emotion among its base. ${ }^{110}$ The Crusader continued publication until it too

lost financial support from the public; the civil rights movement in New Orleans had

been dealt a crippling blow. Rodolphe Desdunes recorded the end of this movement in

his memoir and history of the black Creole people, Nos Hommes et Notre Histoire:

Seeing that the friends of justice were either dead or indifferent, they believed that the continuation of the Crusader would not only be fruitless but decidedly dangerous. Seeing too that the tyranny of their oppressors was limitless, that they were using all their genius to multiply degrading laws against blacks, our people believed it was better to suffer in silence than to attract attention to their misfortune and weakness. We do not share this reasoning. We think that it is more

${ }^{107}$ Barton J. Bernstein, "Case Law in Plessy v. Ferguson,” The Journal of Negro History 47, No. 3 (July, 1962): 194.

${ }^{108}$ Elliott, "Race, Color Blindness, and the Democratic Public," 314.

${ }^{109}$ Plessy v. Ferguson, 163 US 537 (1896): 1.

${ }^{110}$ Logsdon and Bell, "The Americanization of Black New Orleans, 1850-1900," In Creole New Orleans: Race and Americanization, 258. 
noble and dignified to fight, no matter what, than to show a passive attitude of resignation. ${ }^{111}$

But in Desdunes' 1907 affirmation of his willingness to continue the struggle despite the advances of codified white supremacy, he was perhaps more accurately speaking on behalf of his generation than for the black community as a whole. Rodolphe Desdunes, Louis Martinet, Paul Trevigne, and Paul Bonseigneur had all been of the right age to see the promise of the 1868 Constitution. While, through the various social equilibriums which made use of the wide gray areas between Reconstruction and Redemption, between the relatively calm and accommodating 1880 s and the rigid segregation of the late 1890 s, and through the relative lack of racial violence between 1874 and 1900, African Americans and black Creoles had relied on a variety of semiautonomous social and cultural institutions to achieve public satisfaction; in the younger generation this reliance would become more pronounced. To the generation of black New Orleanians who were too young to remember the moments of promise, and whose understanding of the social order was more influenced by the defeat of the Plessy case and strict segregation, finding satisfaction in autonomous institutions focused more on culture replaced the political participation exemplified by black Creoles during and after Reconstruction.

An exception to this trend can be found in Walter I. Cohen, who held a variety of government and Republican Party positions from his work as a page to black leaders

\footnotetext{
${ }^{111}$ Rodolphe Lucien Desdunes, Our People and Our History: Fifty Creole Portraits. Sister Dorothea Olga McCants, trans. and ed. (Baton Rouge: Louisiana State University Press, 1973), 147.

Unpublished in English until 1973, translation of the original French language title sheds additional light on the spirit of the work: Our People and Our History: A Tribute to the Creole People of Color, in Memory of the Great Men They Have Given Us, and of the Good Works They Have Accomplished. Rankin, "The Forgotten People," 77.
} 
during Reconstruction until his death in 1930. Of black Creole and Jewish heritage, Cohen worked closely with Booker T. Washington throughout his career in both philanthropic and professional capacities. Despite his career successes, such as being appointed Register of the United States Land Office in New Orleans in 1898 by President William McKinley, Cohen was frustrated by the efforts of "lily-white" Republicans to diminish his influence and career prospects. ${ }^{112}$ Throughout his career, Cohen was able to retain enough influence to build an association of black-owned businesses as well as receive new placements within the federal government, but the efforts of many within the Republican Party to disavow themselves of black membership and interests make his career unique to a man of his generation. From 1908 onward, Cohen and his family were subject to legal intimidation, including trumped up charges of theft that put his son in prison for two years. ${ }^{113}$

Before fully assessing the changes in social order and their effects on the culture and direction of younger generations of black New Orleanians, however, it is necessary to describe the prevailing strategies of the antagonists to the goals of the black Creole community described in this chapter. Reactionary elements within the white elite of New Orleans bear an innate relevance to the discussion of civil rights, and the process of ethnic white consolidation is key to understanding the deviations from organically established social equilibriums within the context of a society moving, under a concerted legal effort, toward a strict bi-racial and segregated society.

\footnotetext{
112 John N. Ingham and Lynne B. Feldman, “Cohen, Walter I.," In African-American Business Leaders: A Biographical Dictionary (Westport CN: Greenwood Press, 1994), 145-150.

113 Ibid.: 147, 148.
} 


\section{Chapter 2:}

\section{White Consolidation and Influence}

If the agency of the black Creole political caucus and its successes in the 1868 state constitution and subsequent Civil Rights Act, their more short lived successes after 1874 , and their determination to bring court test cases forward to fight the segregation ushered in by Jim Crow were unique, the tide which they were fighting was less so. After Reconstruction, relatively liberal state constitutions and high levels of black political participation throughout the South had been dismantled by powerful Democratic organizations, often through threat of racial violence. Louisiana, however, tended to lag behind other states of the former Confederacy in the dismantling of civil rights protections and the subsequent imposition of segregation, despite the later employment of violent methods similar to those in Mississippi, Arkansas, and the rural Red River parishes of Louisiana's interior.

Social complexities inherent to New Orleans, the state's largest and most powerful city, are responsible for this delay. New Orleans, far from simply representing an anomaly in the socially homogenous South, presents an important discussion of the role of minority populations amidst white supremacist policy. The solutions to the issues of consolidating a Democratic base in a city that was early-held by the Union during the Civil War, boasted not only a large and wealthy free black population but also a cosmopolitan mix of ethnic white immigrants. The manner in which these elements had traditionally found its own social equilibriums is crucial not only in understanding how Jim Crow was constructed in Louisiana, or how New Orleans's pro-civil rights activists 
were defeated, but how the process of consolidating power drastically changed the white community itself.

Louisiana's uniqueness is highlighted by the beginning of the Civil War. The state had been sharply divided during the 1860 presidential election and continued to be so into the Secession Convention of 1861 . New Orleans was key to the controversy over secession, and its role in the Civil War is often omitted from the historical narrative partly because it fell so quickly to Union forces. The South's largest metropolis (in 1860 New Orleans had 170,000 inhabitants; the next largest city in the future Confederacy was Charleston, with about 40,000 inhabitants) took a pragmatic stance on the secession issue, not only because it was home to thousands of Northerners and recent immigrants, but also because its merchants understood the consequences of cutting themselves off from the financial capitals of New York and London and losing the United States' protective tariffs which sheltered them from Caribbean competition in the sugar trade. ${ }^{114}$ During the 1861 Secession Convention, delegates from Orleans Parish, along with twelve others, voted against secession, and when the Ordinance of Secession passed Orleans Parish was among six parishes that refused to sign it. ${ }^{115}$

Nevertheless, changing conditions in rural regions of the state were by the Civil War beginning to have an impact on New Orleans. Immigration to Louisiana from within the United States had a radicalizing effect on politics and perceptions of the status of black Creoles. Anglo-Americans, many from Eastern slave states, attracted to the growing cotton industry in Louisiana from the 1840s onward, imposed their

\footnotetext{
114 Tunnell, Crucible of Reconstruction, 18.

115 Ibid.: 14.
} 
understanding of the racial order on creole New Orleans. The traditional bi-racial social order prevalent in the rest of the South became a reality in the cotton-growing Red River parishes of Northern Louisiana, as well as in the poorer Florida Parishes north of New Orleans. In 1911 Rodolphe Desdunes, editor of the Crusader and organizer of the Citizens Committee, noted that this wave of Anglo immigration was comprised of, “mere adventurers," who, "utilized slavery as their main source of revenue."116

Desdunes's analysis is characteristically in line with perceptions of white Creoles from the time of the Louisiana Purchase, and is telling of his perspective as a classconscious black Creole. While this new economic elite established itself during the 1840 s and 1850 s, not only did the white domination of the free black Creoles become more pronounced, but the expanding cotton industry also brought with it a growing tide of slaves from eastern states. ${ }^{117}$ Over a million slaves were transported from the East Coast to develop the cotton growing regions of Louisiana, Mississippi, and Alabama; many were processed through the auction houses of New Orleans. ${ }^{118}$ After Emancipation, the role of these African Americans became the main point of contention for Louisiana whites, and as discussed previously, a source of difficulty and a missed opportunity for black Creole civil rights leaders.

By the beginning of the1870s, infighting among various factions of the Republican Party, mounting public debts which had begun to grow even before the war, and elections marred by fraud in both parties created a crisis in Louisiana that mirrored

\footnotetext{
${ }^{116}$ Rodolphe Desdunes, Our People and Our History, 111.

${ }^{117}$ Ibid., 111.

${ }^{118}$ Walter Johnson, Soul by Soul: Life Inside the Antebellum Slave Market (Cambridge, MA: Harvard University Press, 1999), 5-7.
} 
the fall of Republican governments across the South. ${ }^{119}$ As African Americans in rural Louisiana were increasingly the targets of ritualized violence and radicals across the state lost political power as the Democratic Party became better able to manipulate elections, reactionaries were in a position to undo the social and political advances of federal Reconstruction.

As Reconstruction came to a close, white elites began an effort to undo the civil rights protections of the 1868 Constitution, as well as the state and federal protections. The Democratic Party was as yet too weak to accomplish this task legislatively in 1873 , leading to the use of the courts. Civil rights legislation was affected by the Slaughterhouse Cases of 1873 in some interesting ways. White New Orleans butchers had brought suit against an 1869 state ordinance which required them to move their operations to a central processing facility downriver. While butchers had long been loathed in the city for using their powerful lobby to avoid such a cleanup in the past, the social and political circumstances of Reconstruction garnered them support from conservative Anglo-Protestant whites. ${ }^{120}$ It is in this regard that the Slaughterhouse Cases represent the consolidation of ethnic-white immigrants under the AngloProtestant dominated Democratic Party. With a new common foe to be found in New Orleans after Emancipation, ethnic rivalries of the past succumbed to a simpler racial rhetoric. Not only was the ordinance another example of the federally backed

\footnotetext{
${ }^{119}$ Tunnell, Crucible of Reconstruction, 172.

${ }^{120}$ Ross, Michael A. "Justice Miller's Reconstruction: The Slaughter-House Cases, Health Codes, and Civil Rights in New Orleans," The Journal of Southern History, 64 No. 4 (Nov. 1998): 656. As another layer of complexity in these events, the white New Orleans butchers in question were predominantly relatively recent immigrants from Gascony, France, referred to locally as foreign French; representing the third wave of ethnic French immigration to New Orleans after the original colonial settlers and the Haitian refugees.
} 
Reconstruction government imposing its will on whites, but since private slaughterhouses in town would be shut down the white owners of these facilities would be put on equal footing with aspiring black butchers who had equal access to the municipally sanctioned facility downriver. ${ }^{121}$

Six cases rose through the court system, reaching the US Supreme Court under the representation of John Campbell, a former Supreme Court justice who had resigned his position to join the Confederacy. Campbell used the Fourteenth Amendment in his arguments precisely because a ruling in his favor would strip the amendment of its power to limit discrimination by narrowing the definition of state action. ${ }^{122}$ The holding of the Court in support of the state regulation has often been construed as being overtly racial in nature, with some scholars alleging that Justice Miller was responsible for purposefully weakening the Fourteenth Amendment. ${ }^{123}$ However, Miller, who wrote his medical school dissertation on the spread of cholera, saw his endorsement of the law as an endorsement of the bi-racial legislature that enacted it, and did not foresee the implications of his ruling in trusting the states to craft civil rights legislation as they saw fit. $^{124}$

By 1873, the Republican leadership of Louisiana had entered what several scholars have termed a crisis of legitimacy. Graft and corruption were certainly widespread, lending credibility to the stereotypical slights of "carpet-bagging" against Northern-born politicians such as Governor Henry Clay Warmoth, a moderate

\footnotetext{
${ }^{121}$ Ross, “Justice Miller's Reconstruction: The Slaughter-House Cases, Health Codes, and Civil Rights in New Orleans," 656.

122 Ibid.: 667.

123 Ibid.: 671 .

${ }^{124}$ Ibid.: 670 .
} 
Republican who grew rich off of state construction contracts. ${ }^{125}$ White conservatives certainly had reasons to be disgruntled with an ineffective government, but white supremacist undertones were likely far more influential in the formation of the White League. Immediately after the Civil War, reactionaries in rural parishes had formed the Knights of the White Camellia, an organization similar to the Ku Klux Klan in Georgia and Tennessee. Later, larger groups with public membership such as the Crescent City Democratic Club paved the way for the White League (which the Crescent City Democratic Club would eventually join as the Crescent City White League). ${ }^{126}$ While the White League officially originated in Opelousas in early 1874 , its fusion with the Crescent City Democratic Club in July of that year under Confederate General Frederick Ogden was the key to its newfound momentum. ${ }^{127}$ The White League was a paramilitary organization which adopted the name of the Louisiana State Militia, parallel to the integrated and legitimate militia that they would eventually fight on Canal Street in New Orleans. ${ }^{128}$ The martial air of the White League was matched by a rhetoric which often boiled down the complexities of Reconstruction Louisiana to literally black and white terms, but was cautious to emphasize that it sought only to end ineffective federal rule.

Although the aims of the White League were appealing to many conservative whites and ethnic immigrants, its membership was decidedly an upper-class affair. Based in part on the circles of conservative elite who had served under General, later

\footnotetext{
${ }^{125}$ See James G. Gill, Lords of Misrule: Mardi Gras and the Politics of Race in New Orleans (Jackson: University Press of Mississippi, 1997), 92.

${ }^{126}$ Gill, Lords of Misrule: 107.

${ }^{127}$ Edward F. Haas, Political Leadership in a Southern City: New Orleans in the Progressive Era, 18961902 (Ruston, LA: McGinty Publications, 1988), 7.

${ }^{128}$ Scott, Degrees of Freedom, 49-59.
} 
Sheriff, Harry Hays in the Civil War and during the 1866 New Orleans Race Riot, the organization was extremely successful in attracting new members. ${ }^{129}$ Key to this success was the effective ostracizing of white political dissidents by Democratic newspapers through the use of the monikers carpetbagger and scalawag, a practice that had dictated political discourse for reactionary Democrats since the Republican-dominated elections of $1867 .^{130}$

By 1873, the average age of Crescent City White Leaguers was between 16 and 25, with most residing in the posh Garden District of Uptown New Orleans. Too young to have participated in the Civil War, but raised on Confederate nostalgia and reactionary outrages against early Reconstruction, these "silk stocking vigilantes" entered the political sphere with something to prove. ${ }^{131}$ A contested gubernatorial election in 1872 gave the White League an opportunity to unite behind the promise of a new, Democratic government. The election was fraught with incidents of voter intimidation in rural parishes, with Democratic and anti-Ulysses S. Grant Republican factions claiming a victory for John McEnry and radical Republicans insisting that William Pitt Kellogg was the legitimate winner. Both candidates were sworn in to

\footnotetext{
${ }^{129}$ Gill, Lords of Misrule, 77.

${ }^{130}$ The term carpetbagger refers to a Northern-born white immigrant to the South after the Civil War with the motive of self-enrichment; it was coined by Montgomery, Alabama Daily Mail in 1867 and quickly became ubiquitous in publications across the South. The origins of scalawag are less known, but its creation can be found in the build-up to Reconstruction as well. The term refers to Southern-born Republicans and moderates and carried a traitorous connotation. See Ted Tunnell, "Creating "The Propoganda of History': Southern Editors and the Origins of 'Carpetbagger and Scalawag," The Journal of Southern History 72 No. 4 (Nov. 2006): 790.

${ }^{131}$ Lawrence N. Powell,"'Reinventing Tradition: Liberty Place, Historical Memory, and Silk-stocking Vigilantism in New Orleans Politics," From Slavery to Emancipation in the Atlantic World, ed. Sylvia R. Frey and Betty Wood (London: Frank Cass Publishers, 1999),131.
} 
office, with McEnry calling to order a competing state legislature made up of reactionary Democrats in $1873 .{ }^{132}$

Paranoia of a purported black league was a major facet of the White League's mission and success. It has even been alleged, however dubiously, that C.C. Antoine, the black Creole Lieutenant Governor under Kellogg, was its leader. ${ }^{133}$ The rumor of a coup to be staged by the state's fictional black league during the summer of 1873 was certainly one motivation for the White League's ordering of a large shipment of guns to equip its units, which upon arrival was quarantined by Governor Kellogg. The city's white elites, also members of the White League, called for a street meeting the next day to protest the incursion on their Second Amendment rights. About six thousand white men of nearly all ethnicities present in the city attended the meeting on September 14, 1874, at which they were told to return to the Clay Statue at 2:30 that afternoon, armed.

Though the initial rally that day was peaceful, the highly organized White League was able to quickly form the crowd into military-style units poised to attack the militia and police, who had hastily responded to the alarm from the seat of government at Jackson Square. The Battle of Liberty Place, which occurred that afternoon at the foot of Canal Street was reminiscent of the Civil War, with organized columns of the White League advancing on the integrated, but mostly white Metropolitan Police and the black state militia, led by former Confederate general and Republican James Longstreet. A suspiciously well-timed freight train along the river gave the White League cover to gain

\footnotetext{
${ }^{132}$ See Scott, Degrees of Freedom, 58, 74; Gill, Lords of Misrule, 104-108; and Tunnell, Crucible of Reconstruction, 150-171.

${ }^{133}$ Stuart Omer Landry, The Battle of Liberty Place; The Overthrow of Carpet-bag Rule in New Orleans, September 14, 1874 (Gretna, LA: Pelican Publishing, 1955),12.
} 
a tactical advantage in the battle, and soon afterward the Metropolitan Police fell back from their position, followed by the black militia. Governor Kellogg and General Longstreet were forced to seek shelter in the federal customhouse. ${ }^{134}$

With Kellogg still hunkered down in the custom house the next day, the Daily Picayune, often a somewhat moderate newspaper caught up in the thrill of the White League's victory, applauded the outcome of the previous day's events, stating that if Kellogg had remained in power the state would have inevitably been Africanized. ${ }^{135}$ In the end, the White League allowed the federal government to temporarily reinstate Kellogg as governor while it made moves to claim the moral and political victory. The para-military nature of the battle was markedly different than the mob violence of the 1866 New Orleans Race Riot, but such restraint was unique to the city. It was in this same 1873 election, which yielded dual Republican and Democratic governments, that Republican holdouts in rural Colfax, Louisiana, along the Red River, attempted to resist a far more violent coup. This resulted in the Colfax Massacre and US v. Cruikshank, the Supreme Court case which in 1875 laid a solid foundation for disenfranchisement. While the White League proclaimed that no blacks had been injured in the Battle of Liberty Place, in fact four of the Metropolitans killed were black. ${ }^{136}$

This declaration was typical of the White League, which often insisted that it was not an overtly anti-black organization. When called before Congress after the events of September 14, 1874, White League executive committee member James Buckner testified that the group had originally been formed and named so without the intention of

${ }^{134}$ Gill, Lords of Misrule: 109-116.

${ }^{135}$ Ibid.: 117.

${ }^{136}$ Ibid. 
operating "against the Blacks," but, “ . . b because we heard of the existence of a Black League." 137 Earlier that year, on November $14^{\text {th }}, 1874$, as the White League made preparations for the 1874 election, it passed a series of resolutions, including a pledge to protect "colored conservatives" from the intimidation of radical black Republicans at the polls. $^{138}$

On December 20,1874, the Daily Picayune gave attention to an appeal by African American leaders to Governor Kellogg claiming that on the Fifteenth of December a meeting of black Republicans in an Uptown church had been attacked by 150-200 White Leaguers. The Daily Picayune was quick to negate their protest, stating, "If the facts are correctly set forth by these colored persons; if they are really peaceable and law-abiding citizens; if they were attacked five times or any number of times ... they have not only been badly treated, but they have been subjected to an outrage which every good citizen must deplore." While denying any culpability of the White League, its members, or its rhetoric in the attacks, the writer was equally quick to point out that, "It is a great error on the part of these colored persons to make this attempt to cast odium on the White League. By making such an effort they only diminish the amount of sympathy which they would otherwise be sure to find among the white people ..." "139 Republicans of both races, of course, were equally troubled by the events of 1874. On January 11, 1875, a Republican mass meeting gathered to hear a speech by General Hugh J. Campbell titled "The White League Conspiracy Against Free

\footnotetext{
${ }^{137}$ Quoted from George Frisbie Hoar, W.H. Wheeler, and Wm. P. Frye, "The White League in Louisiana: Examined by the light of White League Testimony," (New Orleans, 1875), 3.

138 “Colored Conservatives," New Orleans Daily Picayune, Nov. 15, 1874, p.2.

139 “The Colored People and the White League,” New Orleans Daily Picayune Dec. 20, 1874, p. 4.
} 
Government.” Campbell connected the Battle of Liberty Place to the 1866 Race Riot, the Colfax and Coushatta Massacres, as well as similar events across the South, going on to allege that the White League was connected to a multi-state paramilitary network bent on eradicating Republicans from the South. ${ }^{140}$ While connections to organizations outside the state are difficult to prove, the tactics of violence and intimidation used by the White League to control and distort the black vote in Louisiana which Campbell detailed are clear. At several points in the speech, Campbell stressed the numerical disadvantage Democrats miraculously overcame at the polls as well as his disbelief at the percentages of black votes which Democrats claimed in each election. While both parties needed to gain a significant portion of the black vote to win office, Campbell charged that

[in the 1872 election] . . . all the colored men who voted the Democratic ticket in this State, voluntarily and through their own preference, and not from fear either of violence to their persons or lives or of being deprived of their daily bread, could be held in this room upon this platform were I am now standing. ${ }^{141}$

Between the politics of the reactionary White League and radical Republicans, however, the transition period of the early 1870 s was a time when many New Orleanians sought compromise. The same contested 1872 gubernatorial election which had fomented the Battle of Liberty Place had been so rife with fraud on the part of both parties, historian T. Harry Williams opined, “deciding a victor...would have puzzled even a Solomon." It also awakened a desire to move swiftly past the tumult of war and

\footnotetext{
${ }^{140}$ Hugh J. Campbell, The White League Conspiracy Against Free Government (New Orleans: New Orleans Republican press, January 17, 1875), 3,4.

${ }^{141}$ Campbell, "The White League Conspiracy Against Free Government," 7
} 
Reconstruction among both Democrats and Republicans. ${ }^{142}$ As trade languished, a biracial group of civic leaders came forward with the proposition that if blacks were to be free citizens, as the law proscribed, it would be best for the economy and society of New Orleans to quickly reach compromises which would result in a peaceful, working government for the city.

Members of the Unification, or Fusionist, movement, which began in earnest in 1873, sought to unite the races of Louisiana behind the Democratic Party in order to cast off the rule of Republican carpetbaggers, as federal rule was seen by many, especially whites, as the main source of the economic downturn. This "unification" would be accomplished by way of white acceptance of civil rights for blacks, thereby outvoting the extreme, white-supremacist wing of the Democratic Party. ${ }^{143}$ By the summer of 1873, a "Committee of One Hundred" was assembled with Confederate General P.G.T. Beauregard as the head of a smaller committee, proof that many powerful and wealthy white New Orleanians were willing to accept racial equality in order to end political strife. ${ }^{144}$ Black membership in the committee was mostly comprised of wealthy black Creoles. The movement began to sour by year's end, however, when black constituents were critical of prejudices and past policies held and supported by whites. ${ }^{145}$

\footnotetext{
${ }^{142}$ T. Harry Williams, "The Louisiana Unification Movement of 1873," Journal of Southern History 11, No. 3 (Aug. 1945): 349.

${ }^{143}$ Ibid.: $350,351$.

${ }^{144}$ Accepting legal equality was not done without reservations; Beauregard is perhaps the best example of a leader who saw the political expediency of Unification without altering his own personal views on the social equality of black Louisianans. See: Williams, "The Louisiana Unification Movement of 1873," 362.

${ }^{145}$ In contrast, the Readjuster (later Liberal) Party of Virginia was more radical, more successful, and more long-lived than Louisiana's brief flirtation with Unification. Though it eventually succumbed to conservative Democratic pressure in 1883, the party, which successfully controlled Virginia beginning in 1879 , effectively balanced the state's racial dynamics, enabling it to institute reform, especially in public education. See Jane Dailey, "The Limits of Liberalism in the New South: The Politics of Race, Sex, and
} 
The willingness of whites to suddenly endorse the granting of broad political and civil rights had been a fragile platform to begin with, and the rhetoric which reformers had sought to escape through Unification soon entered the debate again, certainly adding another layer to the general feeling of frustration with government in the build-up to the Battle of Liberty Place in 1874. If anything, the Unification movement might have helped to heal war wounds within the white community; in 1877, local Union veterans began the annual tradition of laying wreaths on the graves of Confederate dead on April $6^{\text {th }}$, Confederate Decoration Day (each year after), Confederate veterans responded in turn by donating floral arrangements to Union commemorations. ${ }^{146}$

Amidst the rancor of debate about federal or home rule, it remained clear that the latter specifically meant rule by the Democratic Party elite, the wealthy AngloProtestants of Louisiana. At the same time, some who had been born of similar circumstance and station as the leadership of the White League had come to embrace equality. The writer George Washington Cable serves as an interesting and vital comparison to the members of the White League, in that in his early life he shared many of their bona fides. Cable was from a wealthy Uptown family and was so dedicated to the Confederate cause that he escaped occupied New Orleans as a teenager to serve in the cavalry in Mississippi. ${ }^{147}$ Wounded in battle and remaining in the Army until the war's end, Cable returned to New Orleans and soon dedicated himself to study the

Patronage in Virginia, 1879-1883," in Jumpin' Jim Crow: Southern Politics from Civil War to Civil Rights ed. Jane Dailey, Glenda Elizabeth Gilmore, and Bryant Simon (Princeton: Princeton University Press, 2000), 89, 90; and the relevant sections of Jane Dailey, Before Jim Crow: The Politics of Race in Postemancipation Virginia (Chapel Hill: The University of North Carolina Press, 2000).

146 “At Chalmette: Decorating the Graves of the Federal Dead," Daily Picayune (New Orleans), May 31, 1880: 1 .

${ }^{147}$ Joel Williamson, Crucible of Race: Black-White Relations in the American South Since Emancipation (New York: Oxford University Press, 1984), 94. 
rationale behind the war. ${ }^{148}$ In what he credited as a growing appreciation for freedom and equality as the United States' greatest goals, Cable began his conversion to the Radical Republicans during the late Reconstruction period. ${ }^{149}$ The mob-enforced segregation of a French Quarter girls' school by the White League in 1874 served as a final radicalizing moment for the aspiring author, touching off a period of fiction writing that portrayed New Orleans's black and mixed-race Creole communities. ${ }^{150}$

Cable gained enormous popularity as a fiction writer, but in the 1880 s began branching out into political and historical writing. In 1885, he published "The Freedman's Case in Equity" and embarked on a lecture tour in support of it. Cable's essay discusses other Southern whites who were opposed to increasing segregation but who did not openly protest, as, "their belief is unfortunately stronger in the futility of their counsel than in the power of a just cause." Of this white minority opposed to the "folly" of white supremacy, Cable noted that Southern youth were not well represented. ${ }^{151}$ Cable followed this radical political article with The Silent South in 1885 and The Negro Question in $1890 .^{152}$

In the early 1880s, Cable gained a literary arch-rival in Charles Gayarré, an aging Creole historian who led the charge in vilifying Cable's politics and depictions of local history. In 1884, Cable had hinted in an essay on New Orleans for the

\footnotetext{
${ }^{148}$ George Washington Cable, "My Politics," The Negro Question: A Selection of Writings on Civil Rights in the South by George Washington Cable, ed. Arlin Turner (Garden City, NY: Doubleday, 1958): 10. ${ }^{149}$ Ibid.: 11.

${ }^{150}$ Williamson, Crucible of Race: 94.

${ }^{151}$ George Washington Cable, “The Freedman's Case in Equity,” The Silent South (Montclaire, NJ: Patterson Smith, 1969), 21, 22.

${ }^{152}$ Williamson, Crucible of Race, 94.
} 
Encyclopedia Britannica that all Creoles were possibly of mixed race. ${ }^{153}$ Gayarré's more romantic and homogenous take on history, which left out many of the complexities of New Orleans's Creole society, would win out, however, as his volumes on Louisiana history which emphasized past chivalry and aristocracy (one from 1885 is appropriately titled Creoles of History and Creoles of Romance) became the standard and helped shape the definition of the term Creole. Though Cable was certainly not the first upperclass white New Orleanian to take a radical stance on the question of equality, his public stature as a nationally known writer made him a target for reactionaries in the city, who through slander in the press and a tenfold increase in his property taxes, forced Cable to relocate his family to New England in late $1885 .{ }^{154}$

The fierce rejection of Cable's politics underlines increased white racial militancy towards radicals and moderates by 1876 , when Demorats seized power in the state elections, in an election cycle marred by incidents of voter intimidation. Their victory was hailed as Redemption; "the denouement of a three-act morality play," which had pitted the nobility of the Lost Cause against Republican usurpers. ${ }^{155}$ New Orleans's relative safety in terms of racial violence did not protect it from being influenced by events outside the city. In the bulldozed parishes of the Red River basin, violence against black Louisianans was as pronounced as anywhere in the South after

\footnotetext{
${ }^{153}$ Tregle, Joseph, "Creoles and Americans," Creole New Orleans: Race and Americanization, ed. Arnold Hirsch and Joseph Logsdon (Baton Rouge: Louisiana State University Press, 1992), 175.

${ }^{154}$ Williamson, Crucible of Race: 104.

${ }^{155}$ Dennis C. Rousey, Policing the Southern City: New Orleans, 1805-1889 (Baton Rouge: Louisiana State University Press, 1996), 161.
} 
Reconstruction, and included the Colfax and Coushatta massacres of 1873 and $1874 .^{156}$

In the lead up to the Democratic takeover in 1876, violence against rural black

Louisianans made such a decisive effect on the polls that Northern Republicans in Congress considered it akin to fundraising. ${ }^{157}$

A constitutional convention in 1879 drafted the state's "Redeemer" constitution which neglected to include the protections of equal civil and political rights guaranteed by the 1868 Constitution. ${ }^{158}$ The 1879 Constitution is an important historical place marker, detailing how far the state had come from the era not only of the 1868 Constitution but also from that of the Fusionists and compromise. In the same year a convention of two hundred delegates met at New Orleans to discuss the idea of a mass exodus of blacks westward. In their appeal, speakers at the convention elaborated on the tide of violence which occurred in rural parishes and across the nation, and stressed that emigration posed a greater threat to white planters in "bulldozed" northern parishes than to those in the sugar parishes where labor agreements had made "life and personal liberty comparatively secure." ${ }^{" 159}$

While many black Louisianans did join the 1879 migration to Kansas, it was an impractical move for most. ${ }^{160}$ Conservative whites also consolidated their victories in the commemoration of cultural touchstones, most importantly the Lost Cause, for white

\footnotetext{
156 "Bulldozing," was a common contemporary term used by Republicans and radicals to describe the systematic violence and voter intimidation which quelled opposition to the Democratic Party in rural parishes.

${ }^{157}$ Matthew Frye Jacobson, Whiteness of a Different Color: European Immigrants and the Alchemy of Race (Cambridge, MA: Harvard University Press, 1998), 153.

${ }^{158}$ Scott, Degrees of Freedom, 71.

159 "Emigration: The Subject Discussed in the Colored Convention," The Daily Picayune, New Orleans, April 22, 1879. 2.

${ }^{160}$ John G. Van Deusen, “The Exodus of 1879,” Journal of Negro History 21 No. 2 (April 1936): 112, 120.
} 
society, signaling an era of what one scholar has labeled "invented tradition." ${ }^{161}$ In a speech given on the one year anniversary of the Battle of Liberty Place, Dr. J. Dickson Bruns, one of the signers of the call to the mass meeting on the morning of the battle, lauded the actions of the White League in ending Reconstruction, while also proclaiming "the negro" to be "the bound serf of Radicalism." "162 This depiction not only vilified the hated carpetbagger Republican and negated the agency of black political leaders in the early years of Reconstruction, but also cemented the perspective of the northern "bulldozed" parishes within New Orleans.

The social organization of the white elites behind the Battle of Liberty Place, and much of municipal and state government after the 1874 elections, is interesting in that it was insular and secretive. While the White League's call to meet at the Clay statue on Canal Street had been heeded by six thousand white New Orleanians of numerous ethnicities, whether Creole, German, Jewish, Irish, Italian, or foreign-French, power was concentrated in the hands of relatively small groups of Protestant Anglo-Americans organized not only in the White League, but also in the secretive Boston and Pickwick social clubs. ${ }^{163}$ Members of these elite social clubs were often also members of the city's elite Carnival krewes. In a tradition started by the secretive Comus krewe before the Civil War, New Orleans's Protestant elites appropriated the Catholic Carnival season as

\footnotetext{
${ }^{161}$ Powell, "Reinventing Tradition," 132.

${ }^{162}$ J. Dickson Bruns, M.D., Address to the White League of New Orleans (New Orleans: A.W. Hyatt, Stationer and Printer, 1875), 7.

${ }^{163}$ With Emancipation, the open hostilities between white Creoles and Americans, which were based in ethnicity, nativity, and language rather than race, suddenly shifted. After the Civil War the Anglo-Franco divide in New Orleans was quickly replaced with concern from both Creoles and Anglo-Americans about establishing a new color line. See. Joseph G. Tregle, "Creoles and Americans," in Creole New Orleans: Race and Americanization ed. Arnold R. Hirsch and Joseph Logsdon (Baton Rouge: Louisiana State University Press, 1992), 172, 173.
} 
the culmination of the social season in the city. In the 1870s and 1880s, Mardi Gras was celebrated by increasingly elaborate parades with Anglo themes organized by the secretive Comus and Momus krewes ${ }^{164}$, but also by Rex, the newly dubbed king of Mardi Gras, a krewe which was more open to the public.

Though the Boston and Pickwick clubs, as well as Comus and Momus, are remembered for serving as brokerage houses for the white supremacist movement, notably through their collective members' involvement in the White League, they also represent the upper echelon of ethnic-white consolidation. The first Rex, in 1872, was a Jewish Confederate veteran and member of the Boston Club. ${ }^{165}$ The Jewish population, while certainly not homogenous, was well integrated with Anglo-Protestant New Orleans, and boasted several influential members in the Confederacy and the Democratic Party, as well as the Boston and Pickwick clubs. ${ }^{166}$ The relatively high percentage of German immigrants, which constituted fourteen percent of the white population of New Orleans in 1860, aided in their acceptance by Anglo-Protestant elites. $^{167}$

\footnotetext{
${ }^{164}$ The term krewe was coined by the Comus organization before the Civil War, and began the cultural appropriation of Carnival by Anglo-Americans in New Orleans. More traditional forms of celebration continued, but these new secret societies, with their elaborate structures, parades, and mythology, have become a large part of the city's cultural fabric. Anglo themed parades featured floats reflecting British literature and recent politics absent from more traditional masked reveling.

${ }^{165}$ In later years these krewes would become more anti-Semitic, as the first Rex was also the last Jew to be crowned king of Carnival. Gill, Lords of Misrule: 84-97.

${ }^{166}$ Scott M. Langston, "Jews and Christians in Nineteenth Century New Orleans," Dixie Diaspora: An Anthology of Southern Jewish History ed. Mark K. Bauman (Tuscaloosa: University of Alabama Press, 2006).

Opinions of whites began to shift, however, when immigration patterns brought more Orthodox Eastern European Jews to the city. The changing attitudes even affected the membership of the Boston and Pickwick clubs, as well as Carnival krewes. See: Marcie Cohen Ferris and Mark I. Greenberg, ed. "Jewish Roots in Southern Soil: A New History. (Watham, MA: Brandeis University Press, 2006), 138,139. ${ }^{167}$ Andrea Mehrlander, “'With More Freedom and Independence than the Yankees,' The Germans of Richmond, Charleston, and New Orleans during the American Civil War," in Civil War Citizens: Race,
} 
While some Germans in New Orleans had been Unionists, many served in the Confederacy as well as the White League. The anthem of the Confederacy, a martial take on "Dixie," had been published by a German immigrant. ${ }^{168}$ Particularly well at adapting to the social hierarchy of New Orleans, though, were the Irish, who had wrestled control of the Catholic church from the Creole population of the city and had disproportionately served in the city's police force since the $1850 \mathrm{~s} .{ }^{169}$ The task of managing the politics behind enfranchising New Orleans's diverse ethnic population into the Democratic Party meant for slower consensus building than in more socially hegemonic cities in the South, but it was only one of many moderating influences on the construction of Jim Crow in New Orleans.

Despite increasingly white supremacist rhetoric and the loss of civil rights protections and integrated schools in the 1870 s and 1880s, residents of New Orleans experienced relatively little racial strife in their day-to-day lives thanks to the city's history as a dense, cosmopolitan metropolis. While prejudice and fear no doubt existed in the relationship between whites and blacks in the city, historian Dale A. Somers points out that New Orleans's “tradition of polyglot living” created workable equilibriums for residents of both races to negotiate. ${ }^{170}$ Evidence of such alternative equilibriums can be found in Louisiana's labor movements throughout the late

Ethnicity, and Identity in America's Bloodiest Conflict ed. Susannah J. Ural (New York: New York University Press, 2010).

${ }^{168}$ The publisher was Philip Peter Werlein, a staunch Confederate supporter. His son, Philip Werlein, would become active in the White League. "Werlein, Philip;" "Werlein, Philip Peter," Dictionary of Louisiana Biography, Louisiana Historical Association, http://www.lahistory.org/site40.php (accessed November 10, 2011).

${ }^{169}$ Rousey, Policing the Southern City, 58, 59, 168.

${ }^{170}$ Dale A. Somers, "Black and White in New Orleans," Journal of Southern History 40, No. 1 (Feb. 1974): 21. 
nineteenth century. Before the economic Panic of 1873, white and black longshoremen's and screwmen's unions had worked together to divide jobs on the waterfront fairly between the races to deny employers the opportunity to pit white against black, or vice versa, to lower wages. Cooperation between white and black unions resumed in 1880 , and in 1884 New Orleans's Central Trades and Labor Assembly, which represented over fifteen thousand union members of both races, elected a black member to vicepresidency. ${ }^{171}$ The Knights of Labor, an integrated union, was extremely successful in recruiting urban and rural workers in Louisiana. ${ }^{172}$ In 1887 , white, black, and mixed-race agricultural workers collected under the Knights struck together successfully at the height of the sugar harvest. ${ }^{173}$ The ability of black and white union members to work together continued into the 1890 s. In 1892, unions in New Orleans coordinated a massive general strike that not only included black and white workers, but also skilled and unskilled laborers. ${ }^{174}$

Another example of surprising equilibriums reached in New Orleans during this period can be found in the pursuit of inter-racial marriages. Marriages across the color line, though legality and acceptance fluctuated over time, had been an important feature of New Orleans society since the French colonial era, and the 1866 Civil Rights Act ushered in a new era of acceptance; inter-racial marriage was legal in New Orleans from

\footnotetext{
${ }^{171}$ Somers, "Black and White in New Orleans," 30,31.

172 See Somers, "Black and White in New Orleans," 31; and Scott, Degrees of Freedom, 77, 78.

${ }^{173}$ Rebecca J. Scott "'Stubborn and Disposed to Stand their Ground': Black Militia, Sugar Workers and the Dynamics of Collective Action in the Louisiana Sugar Bowl, 1863-87," From Slavery to Emancipation in the Atlantic World. Frey, Sylvia R. and Betty Wood, ed. London, 1999: 103.

${ }^{174}$ Somers, "Black and White in New Orleans," 32.
} 
1870 to $1894 .{ }^{175}$ Large numbers of inter-racial households and close proximity between black, white, and mixed-race neighbors in New Orleans's densely integrated residential sections promoted the "softening of racial antipathies," according to one scholar, and can be viewed as having a moderating effect on the racial violence, especially against mixed-race relationships, occurring elsewhere in the South. ${ }^{176}$ Even as bifurcated segregation became more formalized in the years after Reconstruction, inter-racial couplings persisted, often in the legal gray area of concubinage, which allowed interracial couples to share assets without a formal marriage.

Alecia P. Long's The Great Southern Babylon tells the story of one such couple, Joseph Mathis and Adeline Stringer. Despite disapproval from his family for pursuing a relationship with a mixed-race former slave, Mathis continued a thirty year relationship with Stringer through increasing difficulty without a formal marriage, even living together for much of the period. By the time of Mathis' death in 1887, the imposition of a bi-racial society was beginning to have an effect on their relationship, which had contributed to their spending time apart as well as planning a move to Jacksonville, Florida, a majority-black city where they hoped to live more anonymously. ${ }^{177}$ Just as Mathis had predicted, interracial relationships were increasingly treated as scandal, evidenced by the attention given to the topic by the tabloid newspaper Mascot from

\footnotetext{
${ }^{175}$ Alecia P. Long, The Great Southern Babylon: Sex, Race, and Respectability in New Orleans, 18651920 (Baton Rouge: Louisiana State University Press, 2004), 10.

The legality of inter-racial marriage had been supported by an 1874 Louisiana State Supreme Court decision which relied on the 1866 Civil Rights Act to determine that inter-racial marriages should be as valid as marriages contracted between whites. See: Peter Wallenstein, "Reconstruction, Segregation, and Miscegenation: Interracial Marriage and the Law in the Lower South, 1865-1900," American Nineteenth Century History 6, No.1 (March 2005): 60.

${ }^{176}$ Blassingame, Black New Orleans, 208, 209.

${ }^{177}$ Long, The Great Southern Babylon, 11.
} 
1890 onward. An 1893 article describing the marriage of a white woman to a black man in the downtown neighborhood of Treme, rich with derogatory language about the character and even odor of the groom, called not for his punishment for breaching an increasingly wide social gulf, but the bride's. ${ }^{178}$

The increasing difficulty of maintaining a shaky social status which had been created by the advances in civil rights during Reconstruction, as evidenced by the difficulties faced by Mathis and Stringer in pursuing a relationship status which was protected by law but decreasingly workable over time, can also be seen in New Orleans's police force. Civil rights legislation had, by 1870, put black police officers on equal footing with their white fellow officers, and black police officers made up roughly twenty eight percent of the force (the black community in 1870 equated to twenty six percent of the total population of New Orleans). However, Democratic control of government after 1874, with the mayor having the discretion to appoint officers at all levels of the Metropolitan Police, had reduced black servicemen to reflect only seven percent of the police officers by 1880; an extremely disproportional relationship as the size of the force and the black community had both grown over the intervening decade. ${ }^{179}$ In the age of patronage, the city's police force was easily manipulated by the office of the mayor, and its composition remained an important facet in the succession of Democratic control.

The Anglo-Protestant elites who had crafted the Democratic takeover of government through the agency of the White League held a tenuous grasp on the party

\footnotetext{
${ }^{178}$ Vincent J. Panteea, “'For Godsake Stop!' Improvised Music in the Streets of New Orleans, ca. 1890,” Musical Quarterly 84 no. 1 (2000), http://www.mq.oxfordjournals.org (accessed October 19, 2010): 19.

${ }^{179}$ Rousey, Policing the Southern City, 137, 139.
} 
itself after their initial success. Rallying support from such a diverse city was likely made easier by the under-dog status which White League supporters espoused during Reconstruction. After the Democratic Party took control of the city in 1876, matters became more complicated. Though white elites and political leaders often shared membership in several clubs or krewes, and shared a common experience in the White League, the Democratic takeover of government brought with it a fracture of the Democratic Party. By 1878 the party split into the more conservative Regular Democrats and more moderate Democratic factions; and by the 1880 s, entrenched politics had become the norm. On one side were the Democratic Conservatives, or Regular Democrats, who represent the growth of a ward-based political machine run largely by Irish immigrants. Opposing them were more traditional elites, who organized various political reform movements, such as the Citizens' Party in 1884 or the Anti-Lottery League in $1890 .^{180}$

Machine political systems were not uncommon in the United States in cities with large immigrant populations, and the opponents of the so called "ring" formed by the Regular Democrats faced new difficulties in building the ethnic-white solidarity necessary not only to preserve their own power, but that of the Democrats as a whole. One powerful tool in influencing the city and future elections was through the appointment of police officers and detectives who carried out mass arrests and other forms of intimidation during elections. The involvement of the conservative Regular Democrats in controlling the police force created an increasingly "adversarial"

${ }^{180}$ Haas, Political Leadership in a Southern City, 103. See Figure 1. 
relationship between police officers and black residents. ${ }^{181}$ When Democratic reform candidates were able to control the city, they instituted policies which were aimed not only at eroding the power of the "ring," but also in cementing their image as the heirs to Liberty Place, politicizing history in a way which had been successful for the White League. It was one such mayor, Joseph Shakspeare, whose last act as mayor in 1882, before ceding his office to "ring" candidate and former sheriff John Fitzpatrick, was to erect an obelisk at the site of the Battle of Liberty Place. ${ }^{182}$

The Liberty Place monument was just one piece of a movement to commemorate a shared white experience in New Orleans, one that emphasized the contributions of reactionary Democrats by memorializing Redemption and the Lost Cause of the Confederacy. Similar to a movement across the South, the success of the 1879 "Redeemer" Constitution was part of a wave of consolidation of Democratic victory. Annual September $14^{\text {th }}$ celebrations in the 1870 s and 1880 s involved a restaging of the battle and ceremonial wreath laying on the graves of fallen White Leaguers. ${ }^{183}$ Reliving the victory of the White League provided an important opportunity to build white consensus. Though the leaders of the league were mostly Protestant, the Catholic majority of New Orleans prompted them to incorporate a solemn mass at St. Louis Cathedral into each year's September $14^{\text {th }}$ observance; a move which historian Lawrence

\footnotetext{
${ }^{181}$ Rousey, Policing the Southern City, 167, 168.

182 Joy J. Jackson, New Orleans in the Gilded Age: Politics and Urban Progress, 1880-1896 (Baton Rouge: Louisiana State University Press, 1969), 75.

${ }^{183}$ Powell, "Reinventing Tradition," 132.
} 
N. Powell considers to have been orchestrated for the express purpose of universalizing the perspective of the Anglo-Protestant elite. ${ }^{184}$

Redemption also brought Confederate pride firmly into the public sphere. In 1876, the city's first formal Confederate veterans' organization, the Association of the Army of Northern Virginia, was founded, quickly followed by the establishment of three similar groups. ${ }^{185}$ This awakening of Confederate nostalgia began to make its mark when, in 1884, Tivoli Circle was rechristened as Lee Circle, with a towering monument erected depicting General Robert E. Lee facing north; never, according to local legend, turning his back on an untrustworthy foe. ${ }^{186}$

The dedication of Lee Circle drew large crowds, notably from the city's white elite, many of whom had participated in the Battle of Liberty Place. Monuments to General "Stonewall" Jackson and statues commemorating the common Confederate soldier were also erected in this period of commemoration, which included, most dramatically, the funeral of Confederate President Jefferson Davis, who died while visiting the city in December, $1889 .{ }^{187}$ One of the more genius aspects of such memorials and monuments to generals is that they emphasized the service of white elites

\footnotetext{
${ }^{184}$ Powell, "Reinventing Tradition," 132.

${ }^{185}$ Kenneth Trist Urquhart, "Seventy Years of the Louisiana Historical Association," presented March 21, 1959. Louisiana Historical Association website, http://www.lahistory.org/uploads/UrquhartLHAHistoryFinal.pdf (accessed December 3, 2011): 7.

${ }^{186}$ Municipal Ordinance 624 CS (1877) New Orleans, http://www.nutrias.org/ nopl/inv/synopsis/c.htm (accessed December 1, 2011).

${ }^{187}$ Municipal Ordinance 7065 AS (1881) New Orleans, http://www.nutrias.org/ nopl/inv/synopsis/c.htm (accessed December 1, 2011);

"Johnston: Unveiling of the Equestrian Statue of the Great Confederate Leader," Daily Picayune (New Orleans) April 7, 1887: 1;

In addition to New Orleans's most elite members of society, the funeral and its procession were attended by 20,000 mourners.

"Twenty Thousand View the Remains of the Lamented Confederate Leader," New Orleans Daily

Picayune Dec. 10, 1889: 1.
} 
on behalf of the public, effectively responding to contemporary Northern critiques of patrician, or aristocratic, rule in the antebellum South while adding to the legitimacy of the Democratic faction which had ushered in Redemption. ${ }^{188}$

The year 1889 was a busy one for the institutionalization of Confederate nostalgia. In June of the same year the United Confederate Veterans, an organization parallel to the Grand Army of the Republic, was established during a convention in New Orleans. ${ }^{189}$ Local Confederate veterans' associations had earlier banded together that February to create a central museum for their relics. After the solicitation of Frank T. Howard, the Howard Memorial Library, just off Lee Circle, was selected. The establishment of a museum prompted Howard to organize Louisiana's first historical association. While tasked with celebrating all of Louisiana history, the true goals of the Louisiana Historical Association are clear in its charter, which carried a special provision giving import to honoring the "War between the States," and in its first board of directors, with appointments to the board equally distributed among Confederate veterans' organizations. ${ }^{190}$ Similarly, the United Confederate Veterans' first historical

\footnotetext{
${ }^{188}$ For information about this process of memorialization and the response to Northern critiques in the South in general, see: Fred Arthur Bailey, "The Textbooks of the 'Lost Cause': Censorship and the Creation of Southern State Histories," The Georgia Historical Quarterly 75 No. 3 (Fall 1991): 510-512.

${ }^{189}$ Herman Hattaway, "Clio's Southern Soldiers: The United Confederate Veterans and History," Louisiana History 12, No. 3 (Summer 1971): 214.

${ }^{190}$ The Louisiana Historical Association was the first to focus on Louisiana history, at least in addition to the history of the Civil War, but it was not the first organization with a similar focus in New Orleans. In 1869 the Southern Historical Society was founded in New Orleans, later moving to Richmond in 1873. The power of such an organization to influence the public's understanding of history is evident in the legacy of historical scholarship into the 1950s and 1960s. The article referenced here, written in 1959, is rife with platitudes of the Lost Cause of the Confederacy and the triumph of Redemption. Kenneth Trist Urquhart, "Seventy Years of the Louisiana Historical Association," presented March 21, 1959. Louisiana Historical Association website, http://www.lahistory.org/uploads/UrquhartLHAHistoryFinal.pdf (accessed December 3, 2011): 7, 9;
} 
committee, which was mandated with the explicit goal of defending the justness of the Confederate cause, was initiated by a New Orleans resident in $1892 .^{191}$

The importance of historical societies, and the power which they wielded to shape public opinion, can be seen in contrasting the post-war legacy of two Confederate generals: P.G.T. Beauregard and James Longstreet. While George Washington Cable had been soundly vilified for his total reassessment of his political beliefs, Longstreet's heroic flaw lies in his moderation. Longstreet's command of the state militia, granted by Republican Governor Henry Clay Warmoth in 1870, was a political placement, with Warmoth hoping that patronage directed toward Confederate generals would appease Democratic interests despite a recent scandal. ${ }^{192}$ With the gravity of surrender hanging heavily on his shoulders, Longstreet approached the politics of Reconstruction as a moderate, unhappy with the prospects of federal rule but eager to abide by the rule of law being crafted by the Republican government. ${ }^{193}$ Longstreet's public esteem, however, had escaped him in the run-up to the 1867 elections. Misgauging the radicalization of the Democratic Party in the buildup to the sweeping reforms of the 1868 Republican state constitution, Longstreet had expressed a readiness to back the experiment of black suffrage, along with a condemnation of reactionary Democrats as

For more information on the influence of Confederate nostalgia in historical associations in scholarly works, see Fred Arthur Bailer, "The Textbooks of the 'Lost Cause:' Censorship and the Creation of Southern State Histories," The Georgia Historical Quarterly 75, No. 3 (Fall 1991).

${ }^{191}$ Hattaway, "Clio’s Southern Soldiers," 216, 217.

192 Tunnell, Crucible of Reconstruction: 161.

${ }^{193}$ William L. Richter, "James Longstreet: From Rebel to Scalawag," Louisiana History 11 No. 3 (Summer 1970): 222. 
anachronistic, in a letter which was leaked to the press and fiercely condemned by conservatives. $^{194}$

If Longstreet's role as the opponent of the White League in the 1874 Battle of Liberty Place did any further damage to his reputation among the Democratic elite, the worst was yet to come. In 1877, the Southern Historical Society's publication (the Southern Historical Society Papers) began to find blame for the loss of the Battle of Gettysburg in General James Longstreet. ${ }^{195}$ In what would become part of the gospel of the Lost Cause, scapegoating Longstreet helped to exonerate General Lee of any fault in the loss of the Civil War. Longstreet, however, proved unenthusiastic in entering the historical debate growing over the war even in self-defense, while Beauregard was an early proponent of using the writing of history as a political tool.

Beauregard had been much more deeply involved in the Unification movement than Longstreet, however, the politically adept Beauregard was more involved for the sake of expediency than heartfelt conviction. The former general would eventually realize his participation in the Democratic Party in his part ownership of the Regular Democratic institution of the Louisiana Lottery, and he was able to preserve his reputation among the white elite through his early adoption, and unwavering support, of the Lost Cause. While Longstreet carried the stain of defeat at Gettysburg, Beauregard's command at Fort Sumter and the First Battle of Bull Run, both Confederate victories carried out before the course of the war turned against the Confederacy, provided a connection which no doubt bolstered the legitimacy of Beauregard's frequent

\footnotetext{
${ }^{194}$ Richter, “James Longstreet: Rebel to Scalawag,”:223.

${ }^{195}$ David W. Blight, Race and Reunion: The Civil War in American Memory (Cambridge, MA: Belknap Press, 2001), 160.
} 
reiterations of his conviction in the justness of the Confederate cause. Beauregard had been an early supporter of the Southern Historical Society in 1869, and his numerous contributions to historical publications continued until his death in the 1890 s. ${ }^{196}$ Like Lee and Johnston, Beauregard would also be honored, in 1915, with a statue in New Orleans; his equestrian statue on Bayou St. John standing, perhaps, as the greatest endorsement of his legacy in the Lost Cause movement. ${ }^{197}$

Through the commemorations of the 1870 s and 1880 s and the dedicated project to establish a parallel historical interpretation of the war, with their unambiguous emphasis on enshrining a pro-Confederate perspective, a new generation of white New Orleanians came of age in an era which celebrated the social and political victories of the Confederacy and the White League. In the fervor of Redemption, the events of Reconstruction, including the 1868 Constitution and subsequent Civil Rights Act, had essentially been removed from the view of the white community and replaced by the hallowed memory of the Lost Cause. After 1889, an outsider visiting the city might have found it increasingly difficult to tell which side of the Civil War had won.

Regardless of which party controlled the city, or of trends of Lost Cause nostalgia within the white community, the Democratic takeover of the state in 1876 and the 1879 Constitution can be seen as the foundation of a growing legal framework of disenfranchisement for black Louisianans. The omissions of the 1879 Constitution had positioned reactionary Democrats to segregate schools in 1879, just as Supreme Court

\footnotetext{
${ }^{196}$ Blight, Race and Reunion, 159, 176.

197 “General G.T. Beauregard," Art Inventories Catalog, Smithsonian American Art Museum, Smithsonian Institution Research Information System, listed under "Doyle, Alexander," www.siris.si.edu (accessed 1/10/2012).
} 
decisions regarding transportation had allowed them to segregate public carriers in 1873 , railroads in 1890, and railroad depots in 1894 . The same is true of the antimiscegenation measure passed in $1894 .{ }^{198}$ This slowly assembled framework not only made it more difficult for civil rights leaders to fight for equality, as each successive law of court decision legitimized more and more discriminatory measures, but it also influenced younger generations of white New Orleanians, who grew up under increasing segregation lauded by their elders as the fruits of their victory at Liberty Place, and expected it to continue.

The pursuit of the Plessy case by the Citizens Committee represents one great, last bout of opposition to this elaborate framework of discrimination. Specifically, statements made at the rally to protest the de facto eviction of Paul Bonseignuer from his north shore residence, mentioned in the previous chapter, show that the pursuit of ethnic white consolidation for the purpose of imposing white supremacy was a process plain to the opposition. In the letter submitted by Albion Tourgée to the rally, the lawyer for the Plessy case called into question a core tenant of white supremacy: that irreconcilable differences between whites and blacks prevented any hope of equality. Tourgée listed various nationalities which had totally acculturated, such as the Irish, Germans, and Scandinavians, but paid special attention to the enfranchisement of Jewish immigrants.

Tourgée's argument consisted, in part, in relating the past brutalities committed against Jewish people in the name of Christianity throughout history. While his characterizations of Jews were mired in stereotype, Tourgée's point rested in the fact

${ }^{198}$ William Cohen, At Freedom's Edge: Black Mobility and the Southern White Quest for Racial Control, 1861-1915 (Baton Rouge: Louisiana State University Press, 2005), 214-217. 
that in the United States Jews had come to terms of equality with white Christians, despite drastic differences of history and religion. With a tone of frustration with the racial politics of the United States, Tourgée asked how it was possible that skin tone somehow mattered more than the various differences of language, religion, history, and culture which had been overcome by immigrants or accepted by white Americans. ${ }^{199}$

While Tourgée was unable to attend the impromptu rally, another leading white activist was able to speak in person. Hamilton Dodley Coleman was a leading businessman in New Orleans, one-time Republican state Congressman, and Confederate veteran described by George Roundanez, a black Creole leader, as a "re-constructed rebel. ${ }^{, 200}$ Coleman represents an important, yet neglected, minority not only in New Orleans, but across the South, as a white, elite proponant of racial equality. His defense of Bonseignuer rested on relating the economic power of New Orleans's black population, a fitting defense for one of New Orleans's wealthiest black Creoles. In listing the achievements of black New Orleanians in the marketplace, as well as campaigns by white business owners to cater to the black market, Coleman argued that, "If the white man could solicit the patronage of the colored man when it involved pecuniary gain...he was inconsistent to object to him in other conditions that entailed absolutely no private social relations."201

Coleman's message, much like Tourgée's, rested on the arbitrary nature of the color line. Their contributions to the discussion shared more similarities than the above, however. Coleman and Tourgée, the only white men speaking on behalf of the Citizens

\footnotetext{
${ }^{199}$ Martinet, Violation of a Constitutional Right, 19, 20.

${ }^{200}$ Ibid.

${ }^{201}$ Ibid.
} 
Committee, were also the only contributors to speak to the issue as it affected the black population as a whole, rather than defending only the black Creole class. The crushing blow which the Supreme Court's decision on Plessy dealt to the black Creole and white activist communities was not only powerful enough to squelch such opposition, but was in of itself a crucial legitimizer of this arbitrary division.

Reactionary Democrats energized by the advances of white supremacy in the early- to mid-1890s put forth extra effort, often boiling down to intimidation in rural areas, to disenfranchise as many working-class, poor, and illiterate voters as possible in order to eliminate the black vote in the 1896 election. They were successful and the new legislature, with but one Republican and one Populist representative amidst the successful Democrats, called for a new constitutional convention. ${ }^{202}$ The 1898 Constitution contained a mechanism which would effectively keep black Louisianans out of politics for generations; a cleverly devised voting criterion which essentially nullified the Fifteenth Amendment in the state of Louisiana. ${ }^{203}$

If one were to vote in Louisiana after 1898, they would not only have to meet the requirements of the grandfather and naturalization clauses, but also property and literacy requirements. ${ }^{204}$ Each successive step of this mechanism was delineated in a separate clause of Article 197, mirroring the successful layering of discriminatory statutes in

\footnotetext{
${ }^{202}$ Scott, Degrees of Freedom, 161.

${ }^{203}$ Ibid: 165 .

${ }^{204}$ Ibid.: 194.

The "grandfather clause" is found in section 5 of Article 197, and states that no citizen who was qualified to vote in the United States on or before January 1st, 1867, nor the son or grandson of any citizen who could vote before 1867, would be denied the right to vote. By protecting the voting rights of those who could vote and their descendents, section 5 effectivly nullified section 1 of the Fifteenth Amendment, which garunteed voting rights regardless of race or past enslavement, in the state of Louisiana. See Louisiana Constitution of 1898, sec. 5, art. 197.
} 
other areas of society. Activists were unable to get judges to look at the whole of Article 197 in their attempts to prove that it violated the Fifteenth Amendment, as each judge found that no specific section explicitly violated the amendment. By this point in time, reactionary Democrats had dropped the cautious language employed by the White League in regards to race. The current governor of Louisiana had remarked after the ratification of the 1898 Constitution that, "the white supremacy for which we have so long struggled ..." was now finally encoded in law. ${ }^{205}$ Missing from this discourse were the platitudes of the White League which excused white supremacy as a mode of protecting black interests; missing also was any reference to the special role of the gens de couleur libres, or black Creoles.

While the mechanisms of Article 197 were well crafted to exclude black Louisianans from the vote, they were equally well worded to preserve the rights of minority white immigrants. Presiding over the 1898 convention was Ernest Benjamin Kruttschnitt, the nephew of former Confederate Secretary of War and Attorney General Judah P. Benjamin, who had served as a sergeant in Company B of the White League during the Battle of Liberty Place. ${ }^{206}$ Kruttschnitt is representative of the elite faction of the Democratic Party at this time; his well-connected family included a brother who served as vice president of the Southern-Pacific Railroad, and Kruttschnitt himself, aided by his membership in social clubs like the Pickwick, held various posts within the government and party throughout his career. ${ }^{207}$ And though Kruttschnitt was certainly

\footnotetext{
${ }^{205}$ Quoted in: Scott, Degrees of Freedom: 164.

${ }^{206}$ Powell, "Reinventing Tradition," 130.

207 “E.B. Kruttschnitt Dead," Fort Worth Telegram, April 16, 1906: 2, http://infoweb.newsbank.com.proxy.lib.pdx.edu/iw-
} 
part of the establishment in Louisiana, he also represents recent patterns in immigration to the city in coming from a German father and Jewish mother. The redefinition of whiteness in Louisiana was crucial to maintain the Democratic Party's hold on the state, and the crisis of black civil rights created the necessity of including the ethnic Germans, Irish, French, and other minorities or recent immigrants, whether or not they had fought at Liberty Place or served in the Confederacy.

Section Five of Article 197 protected recently immigrated Louisianans from being excluded by the disenfranchising suffrage requirements, and especially the grandfather clause, in bold terms: “....and no male person of foreign birth, who was naturalized prior to the first day of January, 1898, shall be denied the right to register and vote in this State by reason of his failure to possess the educational or property qualifications prescribed by this Constitution." What followed this loophole were precise instructions for registering to vote within a three-month grace period. ${ }^{208}$ Though the grace period was short, it is astonishing that such a razor-cut loophole allowed a large section of Louisiana's, and especially New Orleans's, population to sidestep the intricately layered mechanisms designed to circumvent a federal constitutional amendment before the courts. When a liberal white lawyer from Jefferson Parish brought forward a case to test the constitutionality of the voter disenfranchisement mechanism, Democratic lawyers filed a brief that avoided denying the attempt to

search/we/HistArchive/?p_product=EANX\&p theme $=$ ahnp\&p nbid $=$ C60M4EHLMTMyOTcxNDE1OS4 2ODYxNzQ6MToxMzoxMzEuMjUyLjk2LjI4\&p action $=$ doc\&s_lastnonissuequeryname $=7 \& d$ _viewref $=$ search\&p_queryname $=7 \& p \_$docnum $=8 \& p \_$docref $=\mathrm{v} 2: 10 \mathrm{EEA} 3 \mathrm{CFD} 727 \mathrm{D} 370 @ \mathrm{EANX}$ 115521E50280EE20@2417317-115521E598107DF0@1-115521E98147F508 (accessed December 10, 2011).

${ }^{208} 1898$ Louisiana State Constitution, Article 197, Section 5: 236. 
specifically exclude black voters and even sought to prove that the US Supreme Court no longer supported the Fifteenth Amendment, citing US v. Cruikshank and the Slaughterhouse Cases. ${ }^{209}$

The social culmination of this final phase of the legal framework of Jim Crow and the increasingly blatant white supremacist rhetoric behind it can be found in the Robert Charles Riot of 1900, in which the hunt for a black fugitive sparked a wave of anti-black violence throughout the city. The Robert Charles Riot showcases the effects of increasingly violent rhetoric on reactionaries in a city experiencing a low-point in its historically surprising and complex race relations. As in the case of the Battle of Liberty Place, it was again the younger generation of white New Orleanians who were most motivated to pursue violence as a solution to the "Negro problem," inspired by Confederate nostalgia, the successful Democratic takeover of government, and an economic depression. By the end of the nineteenth century, Jim Crow was cemented in Louisiana as well as across the South, the discriminatory laws of the 1890 s and the disenfranchising 1898 Constitution having sealed the fate of New Orleans's once burgeoning civil rights movement.

Residential segregation, however, was slow in coming. New Orleanians continued to live in dense, mixed race and ethnic neighborhoods into the twentieth century, navigating the levels of society in day-to-day interactions with the people of their neighborhoods according to what one scholar has called New Orleans's "live-and-

${ }^{209}$ Scott, Degrees of Freedom, 195. 
let-live" mentality. ${ }^{210}$ The description is not dismissive of the Robert Charles Riot or other flashpoints of racial violence to come, but describes the ability of New Orleanians to associate with each other, however tacitly, despite prejudice and institutional segregation. While there were ground level accommodations and acceptances, the concerted and elaborate efforts of the White League and the reactionary factions of the Democratic Party had accomplished their goal by 1900, achieving white supremacy in the city's public society and politics and preserving their legacy in the monuments and traditions of modern New Orleans. Great power had been wielded in reshaping New Orleans society after Reconstruction, and the 1890s provide numerous windows from which to assess the fallout of such drastic and radical change. ${ }^{210}$ Marquis, Donald. In Search of Buddy Bolden: First Man of Jazz (Baton Rouge: Louisiana State
University Press, 1978), 78. 
Chapter 3:

\section{The Consequences of Social Change}

An argument can be made that, after exploring the motivations and strategies of New Orleans's white and black Creole communities, this chapter should similarly focus on the city's African American population. However, the New Orleans African American community's reliance on inward looking institutions, such as small, Protestant churches, barbershops, and benevolent societies not only distance it from the historical record, making this community's motivations and strategies difficult to trace, but also isolated it during the period. Contributing to these isolating factors are the low literacy and school enrollment rates discussed in Chapter One, and the domination of skilled labor and race issue focused newspaper publication by the black Creoles. ${ }^{211}$ These factors do not make the African American experience in late nineteenth century New Orleans irrelevant, but they do make the impact of social change harder to trace. In place of a dedicated chapter on this community, this paper seeks to highlight key interactions between this community and others in New Orleans, in line with its treatment of the German, Jewish, Irish, and Italian communities. Thus, this chapter will follow the trends and themes established in the previous chapters into an era of drastic change: the arrival of Jim Crow to New Orleans and the social and cultural consequences of its institution.

\footnotetext{
${ }^{211}$ The economic and social isolation of African Americans in New Orleans stands in contrast to the experience of this community in other Southern cities. In Memphis, for instance, the stability of the 1880s had provided African Americans greater opportunities for economic advancement, evidenced in school enrollment and the publication of three black newspapers by 1890 . See Patricia A. Schechter, Ida B. Wells-Barnett and American Reform, 1880-1930 (Chapel Hill: The University of North Carolina Press, 2000), 40, 41.
} 
After the success of Redemption in the late nineteenth century, New Orleans's elite club members, who had begun the process of white consolidation at the Battle of Liberty Place, began to lose control of the social mechanisms that they had established for this purpose. Fear of outside, or more worrisome, black, rule coupled with Confederate nostalgia had served them well after 1874 in establishing a political system solidly under Democratic control and strong enough to begin to lay the foundation of the myriad of restrictions which made up Jim Crow. However, the radicalization of New Orleans's racial dynamic necessary for white consolidation had unforeseen effects on the younger generations of whites. Growing up in an era of increasing racial rhetoric and subjugation of the black community, young conservative whites in the last decade of the nineteenth century brought forth a type of violence unknown to the City of New Orleans. The 1891 lynching of Sicilian immigrants and the Robert Charles Riot of 1900 demonstrate the power that the White League wielded during the Battle of Liberty Place, but without its discipline. Conversely, black New Orleanians, cut off from political participation in public life after the dissolution of the Citizens Committee and the disenfranchising 1898 state constitution, would find new import in seeking their social satisfaction in the vibrant semi-autonomous cultural establishments of the Crescent City. While part of the fallout related to the adoption of a strict bi-racial social order in New Orleans can thusly be described by such acts of violence, beneath the regular ebb and flow of daily life in the city surprising cultural forces were taking shape. Cut out of political discourse despite a noble attempt to question segregation before the US Supreme Court, black New Orleanians, both Creole and African American, continued to 
participate in the cultural life of their communities. Denied an outlet for their ambition in public life, many black New Orleanians sought their satisfaction through their city's rich culture. Benevolent societies (known as social-aid-and-pleasure clubs in New Orleans), secret traditions, festivals, funerals, and inwardly focused musical competition were the new, and only, civic life of black New Orleanians; the development of jazz music is intrinsically tied to each of these outlets. Scholars have had great difficulty in pinning down the specific formula of society and culture that produced jazz music, and while early attempts to detail the birth of this musical force placed too much emphasis on Jim Crow, the changing racial dynamics of New Orleans do play a part. However, if a discussion of black cultural life is important in assessing the fallout related to the imposition of a strict bi-racial order in New Orleans, it is important as well to assess the status of other New Orleanians affected by Redemption and Jim Crow.

Foreign immigrants to New Orleans during the late nineteenth century entered a city with devolving racial equality, but with an expanding concept of whiteness. ${ }^{212}$ The cosmopolitan history of New Orleans certainly aided this acceptance for some, but it was the struggle to cement the white race firmly above black Louisianans after Reconstruction which served as a potent catalyst for acculturation among whites. The Jewish population, while certainly not homogenous, had several influential members in the Confederacy and the Democratic Party, as well as the Boston and Pickwick clubs. ${ }^{213}$

\footnotetext{
212 The term "whiteness" is borrowed from Matthew Frye Jacobson, who breifly discusses how New Orleans experienced accelerated ethnic white acculturation in the relevant sections of his book, Whiteness of a Different Color.

${ }^{213}$ Opinions of whites began to shift, however, when immigration patterns brought more Orthodox Eastern European Jews to the city. The changing attitudes even affected the membership of the Boston and Pickwick clubs, as well as Carnival krewes. See Marcie Cohen Ferris and Mark I. Greenberg, ed. "Jewish Roots in Southern Soil: A New History. (Watham, MA: Brandeis University Press, 2006), 138,139.
} 
The anthem of the Confederacy, a martial take on "Dixie," had been published by a German. ${ }^{214}$ Particularly well at adapting to the social hierarchy of New Orleans, though, were the Irish, who had wrestled control of the Catholic church from the Creole population of the city and had disproportionately served in the city's police force since the 1850 s. $^{215}$ As the nineteenth century progressed, small populations of Filipinos and Chinese had been established in New Orleans, but the most contentious new wave of immigration is found in the Italians.

Before the 1870s, New Orleans's Italian community, which had originated mainly in Northern Italy, had been quickly assimilated and was well represented among Confederate volunteers. ${ }^{216}$ Later Sicilian immigrants were less readily accepted into New Orleans society. Settled mainly in the French Quarter, this marginalized community was quick to find its own equilibrium in its interactions with New Orleans's black population. ${ }^{217}$ Sicilian immigrants worked side-by-side with blacks in the sugar fields and on the docks, even mixing freely during leisure hours, and many white natives began to see the two groups as one, even appropriating a slur formerly used against blacks for the Sicilians: guinea. ${ }^{218}$ Worse yet for the Democratic elite of the city, the

\footnotetext{
${ }^{214}$ The publisher was Philip Peter Werlein, a staunch Confederate supporter. His son, Philip Werlein, would become active in the White League. Dictionary of Louisiana Biography, "Werlein, Philip;" "Werlein, Philip Peter," Louisiana Historical Association, lahistory.org/site40.php, obtained November 10, 2011.

${ }^{215}$ See Chapter Two, page 18.

${ }^{216}$ Russell M. Magnaghi, "Louisiana's Italian Immigrants Prior to 1870” Louisiana History 27, No. 1 (Winter 1986): 64, 68.

${ }^{217}$ For a period of time lasting until the 1920s, the former Creole bastion of the French Quarter was known colloquially as "Little Palermo." See Rousey, Policing the Southern City, 195.

${ }^{218}$ Richard Gambino, Vendetta: A True Story of the Worst Lynching in America, the Mass Murder of Italian-Americans in New Orleans in 1891, the Vicious Motivations Behind It, and the Tragic Repercussions That Linger to this Day. (New York: Double Day and Co., 1977), 56, 57; and Charles Hersch, Subversive Sounds: Race and the Birth of Jazz in New Orleans (Chicago: University of Chicago Press, 2007), 111.
} 
Sicilians tended to support Republican or Populist candidates in elections. ${ }^{219}$ These growing feelings of resentment on the part of native whites spiraled out of control after the 1890 assassination of police Chief David G. Hennessy.

Leaving the police station after $11 \mathrm{pm}$ on October 15,1890 to eat oysters with his friend Captain William J. O’Connor of the private Boylan Police Force, Hennessy was ambushed by gunmen as he walked home. O’Connor was only a few short blocks away after parting with Hennessy, and was first on the scene. When asked what happened, Hennessy told O'Connor that, "They have given it to me and I gave them back the best I could." O'Connor leaned down to ask, "Who gave it to you Dave?" to which Hennessy eventually replied, at a whisper, "Dagos.",220

Hennessy died of his wounds at home not long after the attack. The sensational press coverage of his assassination by parties unknown fueled hysteria about the influence of the mafia in New Orleans. Hennessy had interacted with possible members of the mafia through his capture of an Italian fugitive in New Orleans and by policing the increased involvement of Sicilians on New Orleans's waterfront. ${ }^{221}$ Though the police had no trouble in rounding up nearly a dozen suspects, fear of a greater mafia conspiracy led the mayor to institute a "Committee of Fifty" to investigate. Though nineteen Sicilians were eventually arrested on dubious charges, most were fruit vendors in the French Market, the Committee of Fifty, as well as the rest of white New Orleans, remained suspicious that a greater mafia presence remained to be found, and solicited the Italian community to anonymously submit the names of, "every bad man, every

\footnotetext{
${ }^{219}$ Jacobson, Whiteness of a Different Color, 57.

220 “Assassinated," Daily Picayune (New Orleans) October 16, 1890: 1.

221 "Work of the Mafia,” Daily Picayune (New Orleans) March 18, 1891.
} 
criminal, and every suspected person of your race..." in hopes of dredging up a lead. ${ }^{222}$ When, on March $14^{\text {th }} 1891$, the jury acquitted the first nine suspects, the city was in an uproar. While the jury initially attempted to band together in denying reporters a window into their deliberations, prying correspondents hounded them individually until they talked. ${ }^{223}$ The Daily Picayune published not only each jurors reservations about the evidence presented, but also a short biography and interview in an attempt to sort out why the Sicilians, so obviously guilty to the public at large, had failed to be convicted. ${ }^{224}$ After a mass meeting at the foot of the Clay Statue on Canal Street, a mob of angry white residents stormed the jailhouse that night. They seized the nine Sicilians who had just been acquitted, as well as another five awaiting trial, and lynched them in the street. ${ }^{225}$ The event was a rare moment in history, as it was the largest and boldest lynching ever carried out in New Orleans. ${ }^{226}$ The next morning Governor Francis T. Nicholls received a sharply worded telegram from Secretary of State James G. Blaine, which informed the governor that the Italian foreign minister saw the lynchings as a violation of the treaty between the United States and Italy that guaranteed the protection of Italian citizens within the country. Blaine added that, "The President [Benjamin Harrison] deeply regrets that the citizens of New Orleans should have so disparaged the

\footnotetext{
${ }^{222}$ Gambino, Vendetta: A True Story of the Worst Lynching in America, 148, 150, 151.

223 “They Escape the Gallows," Dallas Morning News March 14, 1891: 1.

224 “None Guilty!” Daily Picayune (New Orleans) March 14, 1891: 2.

${ }^{225}$ Gambino, Vendetta: A True Story of the Worst Lynching in America, 150.

${ }^{226}$ Consequently, this author has found no evidence, excluding the random violence of the 1866 race riot and the Robert Charles Riot of 1900, of any lynching victims, black or white, within the city aside from those described above.
} 
purity and adequacy of their own judicial tribunals as to transfer the passionate judgment of a mob."227

The murders were nearly universally condemned across the country, even if some opinions saw the mob justice employed as necessary but ultimately detrimental to the reputation of New Orleans. ${ }^{228}$ Local opinions in the white community maintained that the lynchings were in fact a necessity, as a way of righting the wrongs of a "corrupt jury. ${ }^{229}$ Despite such entrenched suspicions of guilt, the remaining five remaining Sicilians indicted for the assassination of Chief Hennessy were released after flaws in the evidence and testimony of accusers became apparent in the first trial. ${ }^{230}$ Despite the inability of police and prosecutors to convict any Italians for the 1890 assassination, for decades after the affair Sicilians were often taunted by whites in New Orleans with the question, "Who Killa da Chief?"

The Sicilian community's marginalized status, its downtown location, as well as its history of working and socializing with black New Orleanians all contributed to Sicilian participation in early jazz music in the 1890s. A heritage of brass band music might have been one contributor to the association, but more importantly, Sicilian musicians who grew up in the downtown neighborhoods of the French Quarter and Tremé were naturally in contact with black Creole and African American musicians of the same generation. ${ }^{231}$ Their marginalized status is similar to the position of young

\footnotetext{
227 "Blaine Acts: He Telegrams Governor Nicholls Demanding Protection for Italians," Daily Picayune (New Orleans) March 16, 1891: 1.

228 "Opinions of the New York Press," Daily Picayune (New Orleans), March 16, 1891: 1,2.

229 “Administering Popular Justice,” Daily Picayune (New Orleans) March 15, 1891: 3.

${ }^{230}$ Gambino, Vendetta: A True Story of the Worst Lynching in America, 151.

${ }^{231}$ Hersch, Subversive Sounds, 112, 113.
} 
Jewish musicians of the same time period, as the white Protestant elite of New Orleans began to sever its ties to the city's Jewish community. ${ }^{232}$ That young members of these two otherwise disparate communities became involved in the underground world of early jazz is telling; they were carving out a place and an identity in a surprisingly autonomous culture within New Orleans as opposed to those youths of the same generation, but of a decidedly different status, who found belonging in the growing white hegeonomy of the city.

The beginning of jazz is difficult to reconcile with the poor state of race relations in New Orleans at the end of the nineteenth century. Here is a dynamic, powerful new cultural product created largely by and within the black community of a city which has finally reached its zenith in terms of white supremacy. Historians of jazz have had much difficulty in assessing the importance of the social and political ramifications of Jim Crow in the music's development. Early attempts to study the origins of jazz, led in part by Frederic Ramsey and Charles Smith's Jazzmen of 1939, placed too much emphasis on the idea of a sudden class compression in New Orleans brought about by Jim Crow. $^{233}$. Historian Donald Marquis notes that by the 1930 s many of the first jazz musicians had faded from public view and some had already died. While Marquis praises Smith and Ramsey for beginning serious research into the origins of jazz, he explains that Smith and Ramsey, "[are] responsible for many inaccuracies in subsequent

\footnotetext{
${ }^{232}$ Hersch, Subversive Sounds, 113.

${ }^{233}$ Jazzmen was the first book on jazz written by American authors, and the first to delve into the origin of the music in New Orleans. The first book to analyze and describe jazz itself was Hot Jozz by Hughes Pannassie, published in 1936; though it dealt only with the jazz musicians and style of jazz music that had reached the author in France.
} 
jazz histories only in that Jazzmen was accepted as a bible and was widely quoted."234 Among these inaccuracies was the inflated importance placed on Storyville, New Orleans's famous red light district, which Marquis states was only a venue for piano players at most, not early jazz bands. ${ }^{235}$ This amendment to accepted jazz history is reinforced in Jelly Roll Morton's recollection of early jazz pianists, when he describes how piano players were employed in Storyville and played with jazz bands after work and in different parts of town. ${ }^{236}$

The real origins of jazz were much more interwoven into the daily cultural happenings within the black community of New Orleans. In analyzing jazz history, many scholars have adapted Lawrence Gushee's omnium-gaterum approach, accepting a wide variety of cultural influences which exerted more or less influence in evolution of jazz both among and within the African American, black Creole, and ethnic immigrant communities of New Orleans in the 1890 s. $^{237}$ This approach is mirrored by historians who grapple with the numerous social components at play during jazz's development, and more recently a great deal have been accepted. While the contribution of classically trained black Creole musicians has been recognized, in addition to the large degree of musical literacy and expertise within the African American community, the importance of Jim Crow, the 1896 Plessy decision, and the changing racial dynamic in general are

\footnotetext{
${ }^{234}$ Marquis, In Search of Buddy Bolden, 3.

235 Ibid.: 58 .

${ }^{236}$ Alan Lomax, Mister Jelly Roll: The Fortunes of Jelly Roll Morton, New Orleans Creole and "Inventor of Jazz” (Berkeley: University of California Press, 1973), 42.

${ }^{237}$ Mark McKnight, "Charivaris, Cowbellions, and Sheet Iron Bands: Nineteenth-Century Rough Music in New Orleans," American Music 23, No.4 (Winter 2005): 421.

Also: Lawrence Gushee, “The Nineteenth-Century Origins of Jazz," Black Music Research Journal 22 (2002): 155-172, for an overview of his approach.
} 
still difficult to place. ${ }^{238}$ The simple answer might be that there was enough going on within the black music community, still eschewed between the black Creoles and African Americans, to keep musicians sufficiently busy in their own right, regardless of increasing segregation.

The importance of classically trained and musically literate musicians is essential to this concept, as is the sheer size of the population of professional and part-time musicians and the ready availability of jobs, regardless of segregation. Historian R. Collins describes what he terms the African rhythm fallacy, in which he debunks the long held belief that jazz music was deeply influenced by pure African rhythms by arguing that the poly-symphonic nature of jazz was early on confused with the syncopation of African American rhythms. ${ }^{239}$ This notion is one fragment of recent scholarly work reevaluating the simplistic early explanations of the origin of jazz, and one that similarly reflects the importance of music teachers and competition between musicians within New Orleans's distinct black communities. If one were to be a paid musician in New Orleans, after seeking out training from a renowned local teacher or one educated in a conservatory in Mexico City or Paris, one then had to vie for lucrative open seats in a band by passing a series of informal tests, such as adapting to changes in the rhythm, melody, or time signature with little or no warning. Once accepted into a band, the competition between bands for venues and crowds began. A variety of dance halls, often operated by social aid-and-pleasure clubs, were available to and competed

\footnotetext{
${ }^{238}$ Thomas J. Hennessey, From Jazz to Swing: African-American Jazz Musicians and Their Music, 18901935 (Detroit: Wayne State University Press, 1994), 20.

${ }^{239}$ R. Collins, New Orleans Jazz: A Revised History: The Development of American Music from the Origin to the Big Bands (New York: Vintage Press, 1996), 22.
} 
for by both African American, black Creole, and later in the twentieth century, ethnically mixed bands. It was this competition, with its emphasis on employing polysymphonic rhythms and melodies, which perhaps was most influential on the development of jazz. ${ }^{240}$ The vibrant proving ground for a new musical force that such competition created is also evident of the potency and liveliness of cultural life for black New Orleanians beneath the aura of increasing segregation and the notice of most whites.

A potent example of the black community's ability to construct an autonomous, hidden society which not only sequestered itself beneath the notice of the white elite, but even structured itself to stand in mysterious defiance can be found in the Mardi Gras Indian tradition of New Orleans. The tradition began during a Carnival close to the 1884 visit of Buffalo Bill's Wild West Show when black Creole Becate Batiste was inspired by visiting Lakota to form the first Mardi Gras Indian tribe; the Creole Wild West. Donning elaborate headdress to circumvent a law forbidding blacks to wear masks during Carnival, other tribes quickly began to form throughout New Orleans's neighborhoods. While it had always been part of Carnival tradition to dress in costume for the festivities, Mardi Gras Indian tribes evolved into tight-knit hierarchical societies that carried precise and complex traditions in the same manner and dress year after year. $^{241}$

From the outset, the origin of the Mardi Gras Indians was obscured in myth. While many of the "Indians" themselves describe their involvement in the tradition as a

\footnotetext{
${ }^{240}$ Collins, New Orleans Jazz, 93, 171, 172, 188-191.

${ }^{241}$ George Lipsitz, "Mardi Gras Indians: Carnival and Counter Culture Narrative in Black New Orleans," Cultural Critique 10 (Autumn 1988):104.
} 
connection to the shared resistance of black slaves and American Indians against the colonial white society, the homage paid to Native Americans through the dress, dances, and secret language of the Mardi Gras Indians shows no influence of local tribes, but rather that of Africa, the Caribbean, and creole Louisiana itself. Scholars describe the elaborate tradition of the Mardi Gras Indians as a "counter-narrative" to the white community’s Carnival tradition, which promotes a parallel cultural hierarchy well hidden from the dominant society. ${ }^{242}$

Scholars such as Richard Brent Turner and Joseph Roach point to the process of "surrogation" in the black communities of the New World, especially New Orleans, to explain the connection between legend and the historical record. This process entails the reconciliation of violent cultural memories and the break, or disconnect, with African heritage created by the institution of slavery by way of creating a heritage which honors forgotten experiences of the past through the construction of a new identity. Thus, by creating a "ritualized memory," Mardi Gras Indians found a way to honor historical events, such as the Natchez Rebellion of 1729, and other interactions between blacks and Indians not discernable in the accepted historical narrative. ${ }^{243}$ That the first Mardi Gras Indian tribe was black Creole in origin is paradoxical; one of the most important colonial origins of the black Creole class itself was in the needs of the colony to provide slaves an incentive to fight in militias against Indians in the mid-eighteenth century. This new take on history, which stressed black resistance during the colonial period, is related to the expansion of the concept of whiteness. If the complexities of New Orleans's

\footnotetext{
${ }^{242}$ Lipsitz, "Mardi Gras Indians," 115.

${ }^{243}$ Richard Brent Turner, Jazz Religon, the Second Line, and Black New Orleans (Bloomington: Indiana University Press, 2009), 40, 41.
} 
cosmopolitan ethnic history could be boiled down to white and black by Democrats and the White League, then too could a more inclusive interpretation of black oppression and resistance take hold in the collective understanding of New Orleans's black communities.

Traditional Mardi Gras Indian songs may trace their origins to the Caribbean of Africa, and the secret language is more influenced by French and Spanish than any Indian language, but it is the spirit of defiance against the impending dominance of white society which the Mardi Gras Indians originally saw in the visiting Lakota which provides their most direct link to Native Americans. ${ }^{244}$ The Mardi Gras Indian tradition, second only to its importance as a pillar of black culture in New Orleans, is a street theatre, where black New Orleanians may act out tests of manhood, display hidden knowledge and heritage, and perform other rituals which symbolically protest the status quo of a racially rigid society.

The existence of such a vibrant secret society, replete with its own mythology and secret hierarchies is not surprising in New Orleans, but its success in surviving, and even growing, given the state of increasing hostility between white and black residents might be. While the Mardi Gras Indians serve as an extreme example of an underground society, they represent the ability of black New Orleanians to find social and cultural satisfaction despite being cut off from participation in politics and the larger society as a whole. Benevolent societies, or social-aid-and-pleasure clubs, were a major facet of public life for New Orleanians. Such organizations had existed within the black community since the eighteenth century, and membership was often defined by ${ }^{244}$ Lipsitz, "Mardi Gras Indians," 476. 
geographic and, more importantly, economic niches before the bi-racial order developed after Redemption. ${ }^{245}$ The clubs functioned much like other benevolent societies in the United States; providing burial and health assistance in exchange for membership fees, but the culture of New Orleans added an important facet to their operations.

Social-aid-and-pleasure clubs provided the black community with a muchneeded outlet for responsibility in public life, and membership in such organizations was celebrated through events such as street parades and balls or concerts at the organization's hall. It is in this celebration that the social-aid-and-pleasure clubs, like the Mardi Gras Indians, exerted an influence on the evolution of jazz. ${ }^{246}$ Many scholars credit the intermingling between cultures that these organizations provided, often set to music in a dance hall or on parade, as the starting point of jazz. The numerous funerals and functions of these benevolent societies guaranteed the employment of a large number of professional brass band musicians, as well as a rich training ground for young musicians. ${ }^{247}$ The music these brass bands played at funerals was jubilant, as the local custom is to "rejoice at death," and the bands themselves often had jubilant names, such as Excelsior and Onward. ${ }^{248}$ This outlook is important in assessing how such a jubilant music as jazz became the hallmark of New Orleans amidst Jim Crow, and to historians such as Turner, forms another crucial link connecting the second line music of parades and funerals and the subsequent development of jazz to other diasporic cultural themes

\footnotetext{
245 Claude F. Jacobs, "Benevolnet Societies of New Orleans Blacks during the Late Nineteenth and Early Twentieth Centuries," Louisiana History 29, No.1 (Winter, 1988): 22, 23.

${ }^{246}$ It is telling of the importance of such activities that Jelly Roll Morton, though known to brag and enhance his experience in interviews, not only gave a great deal of information on social-aid-and-pleasure clubs, the second line, and Mardi Gras Indians, but also emphasized his participation.

See: Lomax, Mister Jelly Roll, 11-15.

${ }^{247}$ Marquis, In Search of Buddy Bolden, 32.

248 Ibid.: 33.
} 
in the black community. ${ }^{249}$ This interpretation is central to more recent scholarship evaluating the cultural roots of New Orleans music and their connection to social paradigms.

Vestiges of the class bias between black Creoles and African Americans persisted in the late nineteenth century, despite increased association in the form of benevolent society membership, participation in the Mardi Gras Indian tradition, participation by the younger generation in the evolution of jazz, and the racially compressing weight of white supremacy. The association of younger black Creoles with African Americans in bands and as audience members was a source of concern for many in the black Creole community. Many black Creole musicians even refused to interact with their African American counterparts, citing in irreconcilable difference in the manner they were raised and their cultural perspective. ${ }^{250}$ Musicologist Alan Lomax provides a list of Creole musicians around the turn of the century and their occupations. Titles such as laborer and longshoreman, common vocations for the descendants of former slaves, are nonexistent on the list, which includes fine carpenters, a large number of cigar makers, shop and restaurant owners, and professional musicians. ${ }^{251}$ The compression of the black Creole and African American classes to fit the bi-racial order established by segregation, alluded to by historians before the 1970s, remained a long time coming in New Orleans.

Within the community of musicians, there were also divisions on the amount of musical education one possessed, which have come to light through recent scholarship

\footnotetext{
${ }^{249}$ Turner, Jazz Religion, the Second Line, and Black New Orleans, 48-51.

${ }^{250}$ Hersch, Subversive Sounds, 64, 65.

${ }^{251}$ Lomax, Mister Jelly Roll, 70.
} 
which emphasizes the black Creole, with its community's heritage of classical musical literacy, influence on jazz. ${ }^{252}$ In an interview with Lomax, Creole clarinet player Alphonse Picou described his musical upbringing. Born in 1879 , he took music lessons at New Orleans's French Opera House and played traditional French quadrilles at parties before joining Manuel Perez's jazz band. ${ }^{253}$ Louis Tio, another Creole clarinet player, was educated at Mexico's classical music conservatory in Mexico City, as were other members of his family. ${ }^{254}$ A high demand for musical excellence, as well as excellent music teachers, was shared by black Creole and African American musicians and audiences, albeit in mostly parallel arrangements until the twentieth century. Despite lingering antagonisms of class and history, the development of jazz is a bright spot in the otherwise devolving state of New Orleans society in terms of equality. The 1898 Constitution, its cementing of Jim Crow in Louisiana, and the culture of white supremacy nurtured by Redemption all contributed to the nadir of race relations in New Orleans: the Robert Charles Riot of 1900.

Robert Charles was an African American from a poor farming family in Mississippi who moved to New Orleans in 1894 in hopes that the size and complexity of the city, as well as its relative lack of racial violence, would provide anonymity and shelter from the brutal conditions he experienced through the violent race relations of his home state. He was part of a sizable tide of migration; about two thousand other black

\footnotetext{
${ }^{252}$ Hersch, Subversive Sounds, 66, 67.

253 Ibid: 79.

${ }^{254}$ Marquis, In Search of Buddy Bolden, 76.
} 
Mississippians moved to New Orleans for similar reasons throughout the $1890 \mathrm{~s} .{ }^{255}$ No doubt inspired by the violence in Mississippi, Charles had become extremely disillusioned with the future of race relations in the United States, and by 1896, he had become involved with the International Migration Society, selling subscriptions to their literature and even putting a deposit down on his own eventual emigration to Liberia. ${ }^{256}$ Though he may have planned an escape, Charles was still trapped in a continually devolving racial struggle in the United States.

In the summer of 1900 , Confederate veteran and editor of the States newspaper Henry J. Hearsey arrived at the solution to the "Negro problem." He predicted that if Louisiana blacks continued to allow themselves to be agitated by Northern civil rights activists, whom he no doubt blamed for recent pursuit of the Plessy case, a race war would be inevitable; a war which would result in their extermination. As an alternative solution to this eventuality, Hearsey suggested that black Louisianans submit themselves to an even more repressive social and legal arrangement than what existed in 1900, an arrangement that can hardly be imagined. ${ }^{257}$

Hearsey, a bombastic personality with a penchant for dueling journalistic rivals, had long been a fixture in the White League and Democratic party of New Orleans. ${ }^{258}$ Born in rural West Feliciana Parish, Hearsey’s journalistic career took him to Mississippi before serving for the Confederacy; it was when he mustered out as a Major

\footnotetext{
${ }^{255}$ William Ivy Hair, Carnival of Fury: Robert Charles and the New Orleans Race Riot of 1900 (Baton Rouge: Louisiana State University Press, 1986), 68, 94.

${ }^{256}$ Hair, Carnival of Fury, and Ida B. Wells-Barnett, "Mob Rule in New Orleans," in On Lynchings: Southern Horrors, A Red Record, Mob Rule in New Orleans (New York: Arno Press, 1969).

${ }^{257}$ Hair, Carnival of Fury, 91, 92.

258 “Under the Oaks,” Daily Picayune (New Orleans), January 28, 1880.
} 
that he acquired the title he used throughout the rest of his life. It was during his work at a Shreveport newspaper after the war that Hearsey began to develop the style by which he would be known. An obituary writer later described the situation in Shreveport at the time as having, "the negroes in full possession of the local government," and that,

Their oppression in office and [Hearsey's] natural and firm belief in the domination of the white race aroused an ire in his breast which he gave vent to through the columns of the Times, and the clarion calls which he sounded to the white men of north Louisiana roused them to action, which resulted in the overthrow of the black hordes all along the Red River valley. This is the movement which gave inspiration to the white men of south Louisiana, and the White League completed his work in New Orleans in $1874 .^{259}$

The Times-Democrat ran a similar series of solutions to the "negro problem" that same summer; highlighted by the suggestions of Dr. Gustav Keitz, which included deportation to the Philippines and compulsory sterilization soon after birth. ${ }^{260}$ Hearsey and Keitz's plans for the black population of the state were in line with rural perspectives, though Hearsey's influence in the White League circles of urban New Orleans was pronounced. Major Hearsey had been scheduled to be a pallbearer at Jefferson Davis's funeral in 1889 (but was absent due to illness), and he was well involved with the Democratic Party. What is interesting about Hearsey's influence through his newspaper though, is that it represents a change in the terms of racial strife. Long gone from this discourse were the platitudes typical of the White League after the Battle of Liberty Place, in which the public was assured that local control of government was sought for the protection of black Louisianans; two decades of increasing segregation had created an even more remote other of this segment of society more

259 “The Death of Major Hearsey," Daily Picayune (New Orleans), October 31, 1900.

${ }^{260}$ Hair, Carnival of Fury, 141,142. 
deserving of harsh language and tactics than before. In the summer of 1900, the rhetoric of white supremacy circulating in New Orleans's press reached a critical point.

On the night of Monday, July $24^{\text {th }}$, Robert Charles and his associate Leonard Pierce were ostensibly waiting for their dates for the evening outside a house on Dryades, near Washington Avenue. The uptown neighborhood was mostly white, but integrated, as most New Orleans neighborhoods were, and most those gathered outside after dark to escape the heat that night were black. ${ }^{261}$ Charles had recently written the president of the International Migration Society to request more pamphlets to distribute in his hometown in Mississippi, as he had given out his entire supply. When Charles and Pierce were confronted by three police officers that evening for loitering, Charles was rapped by an officer's club. Charles snapped, drawing a gun and wounding the officer before fleeing toward his home. ${ }^{262}$ Charles had been wounded by a policeman's bullet in his flight, and was hiding in his apartment on Fourth Street when a squad of patrolmen approached. Charles killed the first two officers to approach and the others hid themselves, one running several blocks away, leading later to charges of cowardice and ineptitude on the part of the police force. ${ }^{263}$

Charles escaped while the policemen remained in hiding, and the city awoke the next morning to a manhunt. A reward was placed on Charles's head, and the excitement over the fugitive carried over into the following day. That night, a large gathering took place at Lee Circle, at the base of the recently constructed monument to General Robert

\footnotetext{
${ }^{261}$ Hair, Carnival of Fury, 141, 142.

${ }^{262}$ Accounts differ as to whether Charles drew his gun before the officer; one account depicts the officer drawing his gun first after Charles seized his club. See Wells-Barnett, "Mob Rule in New Orleans," 6-9.

${ }^{263}$ Wells-Barnett, "Mob Rule in New Orleans," 10,11.
} 
E. Lee. Unlike the Battle of Liberty Place, which had begun with a rally at the Clay Statue to decry grievances against federal rule, this gathering lacked the military discipline and leadership of the White League elite. The crowd which assembled was young, "not many of them over 21 or 25 years old," made up of about, "100 small boys and some 250 older rioters," and leaderless. ${ }^{264}$ After being dispersed from the circle by police, the crowd moved down St. Charles Avenue amid chants of, "Catch a nigger anywhere you can find him.",265

The first black man the mob encountered was defended by an intervening white man, allowing his escape, but the crowd continued to increase in size as it moved downtown. In fact, several whites attempted to quell the violence as the crowd grew, but none were heeded. ${ }^{266}$ The Daily Picayune reported the next day that it was, "the little boys [who] talked the loudest of anyone," as the mob's energy swelled. ${ }^{267}$ With the goal of the march yet to be defined, an older man in the crowd commanded its attention to give a rallying speech. He claimed to be the mayor of Kenner, a small village upriver from New Orleans, and newspapers of the time were cautious in reporting that he claimed to be the mayor of Kenner. ${ }^{268}$ This man boasted that in his town 500 blacks were held in check by only five whites, and that the assembled should proceed to kill all the blacks they encountered as they were, "all equally bad." ${ }^{269}$ Other reports indicate that this man proposed the idea of proceeding to the parish jail to lynch Pierce, who had been

\footnotetext{
264 "Negroes Hunted All Night by Mobs Made Up of Boys," Daily Picayune (New Orleans), July 26, 1900: 1 .

${ }^{265}$ Ibid.

${ }^{266} \mathrm{Ibid}$.

${ }^{267} \mathrm{Ibid}$.

${ }^{268} \mathrm{Ibid}$.

${ }^{269}$ Ibid.
} 
arrested quickly after Charles's first shot, stating that the only way to put the black population of New Orleans in its rightful place was to, "go out and lynch a few of them as an object lesson." 270

The mob proceeded to the jail only to be thwarted by the police, who, rather than venture out into the city to prevent violence against blacks, had centered their efforts on the jail to prevent its storming, and a repeat of the lynchings that had occurred just a few years earlier when Sicilians suspected of killing Chief Hennessy were lynched. On meeting this obstacle, the mob fractured in two, with one arm heading downtown into Treme, and the other proceeding uptown. The downtown wing was led by a man named Pepe Roses. Just a year before, Roses' political affiliations had become news after his attempt to kill, in a bar brawl he initiated, three supporters of a candidate running against the mainline Democratic candidate for a post in the sixth ward. ${ }^{271}$ It is plausible that Roses' role in the Democratic Party was that of an enforcer, though he was well known in newspapers as a villain. Roses' role as a leader might be a bit of a misnomer, as each branch of the mob roamed the city indiscriminately attacking any black resident they could find. It was Roses' faction that committed the first murder that night, stopping a streetcar on Villere in order to beat its sole black rider to death. ${ }^{272}$ Luckily for some, and unluckily for others, the late hour of the riot gave many black residents time to make it home from work, while others were caught on the streets.

\footnotetext{
${ }^{270}$ Wells-Barnett, "Mob Rule in New Orleans," 14.

271 "Pepe Roses," Daily Picayune (New Orleans), September 13, 1899: 6; "Pepe Roses Again Held for Murder," Daily Picayune (New Orleans), October 7, 1899: 7.

${ }^{272}$ Wells-Barnett, "Mob Rule in New Orleans," 14, 15.
} 
By the time the rioters dispersed, four black New Orleanians had been killed, including Baptist Thilo, who was 75 years old. Five blacks were wounded, one of which was a woman, in addition to three whites who were accidentally hit by stray bullets fired by the crowd. ${ }^{273}$ The indiscriminate nature of the attacks was a surprise and embarrassment to the community at large. The Daily Picayune reported that the riot's victims, rather than being deserving targets of vigilantism, were made up of, "only the unsuspecting and inoffensive, hard-working negroes." ${ }^{274}$ While the acting mayor issued a proclamation asking the general public to not assemble in the streets and let "justice take its course," rather than attempting to take, "the law into their own hands," Charles's flight was coming to an end. ${ }^{275}$ Gangs of violent white youths continued, regardless of the proclamation, to range over the city in search of blacks to harass, and the situation remained out of hand even as the mayor assembled a posse of 1,000 white residents to assist the police. The police did not find Charles until Friday, and when they surrounded the house where Charles was sequestered they were still unable to take him. Under a hail of fire, Charles, who had acquired a rifle, killed three of his pursuers and wounded 11 more. Frustrated with their inability to root out Charles, the police and volunteers assembled set fire to the house. Charles was shot and killed by a medical student as he attempted to escape to another building on the property; his body was brought out to the street for the shooting practice of the crowd assembled. ${ }^{276}$

\footnotetext{
273 "Negroes Hunted All Night by Mobs Made Up of Boys," Daily Picayune (New Orleans), July 26, 1900: 1 .

274 Ibid.

${ }^{275}$ Ibid.

${ }^{276}$ Wells-Barnett, "Mob Rule in New Orleans," 20,21.
} 
Though the race riot which had occurred during Robert Charles's flight was seen as an embarrassment by many white New Orleanians, one fact more easily agreed upon was the poor character of Charles himself. In the days after the violence, the black community likely tried to reconcile their image of Robert Charles as well. An African American Methodist minister gave a sermon titled, "Afterthoughts, or Lessons from the Riot," which used the life of Robert Charles as a warning. "There was certainly no excuse for Charles's resistance," the preacher explained, and despite reading in a "northern paper that he was a hero," he suggested, "this view is entirely false.",277 Charles's defiance of overtly hostile police officers was dangerous; the reverend went on to explain that the black community's, "constant harping over past wrongs," and agitation for more equitable social conditions would lead them to the same destruction as the Indians. ${ }^{278}$ Charles's politics had become common knowledge after his books and pamphlets were discovered by police, and while his activism with the International Migration Society was seen as suspicious to certain white members of the press, antilynching activist Ida B.Wells-Barnett stressed, in a pamphlet she printed just a month after the shootings and riot, that there was not a hint of violence or retribution against whites to be found in the Charles's literature. Wells-Barnett also called into question Charles's characterization by the press as a "desperado," explaining that Charles acted in self-defense. It just happened that his self-defense consisted of deadly aim and a remarkable endurance to sustain injuries. ${ }^{279}$

\footnotetext{
277 “A Pulpit Plea for the Black Race,” Daily Picayune (New Orleans), August 20, 1900: 3. 278 Ibid.

${ }^{279}$ Wells-Barnett, "Mob Rule in New Orleans," 33-40.
} 
Desires similar to those of the "mayor of Kenner" to subjugate black Louisianans had found another outlet in the summer of 1900, when a campaign to segregate New Orleans's streetcars began. Streetcars had been briefly segregated after the Civil War, but a successful strategy of civil disobedience organized by black Creole newspapers had ensured their integration. Early in July, the state legislature began discussing a new separate car bill, one which did not find support in New Orleans. Local white residents worried about the increased logistics of segregated public transit, from the fact that, "Conductors will make serious blunders by assigning dark-complexioned white people (of whom there are many in this city) to negro cars," to the fact that white men would simply not wait for a white car to approach, leading to de facto integrated rider-ship. ${ }^{280}$ There were also concerns about white "hoodlums" vandalizing the black cars at the expense of the city and the co-mingling of different economic classes from both sides of the color line. ${ }^{281}$ While some brainstormed solutions to try to keep a segregated streetcar system efficient, such as having cars pull trailers, the idea remained unpopular; the only newspaper in New Orleans to endorse segregation of streetcars was the one edited by Major Hearsey. ${ }^{282}$ New Orleans's mayor, city attorney, and city engineer even petitioned the state senate to leave the regulation of city transit to the city itself. ${ }^{283}$

The legislative session came to an end before a bill was passed, but as Harry D. Wilson, the bill's author and a representative of rural Tangipahoa Parish, summarized in October, "If the Robert Charles affair had happened while my bill was pending or before

\footnotetext{
280 “The Separate Car Bill," Daily Picayune (New Orleans), July 3, 1900: 4.

281 "The Separate Car Bill," Daily Picayune (New Orleans), July 3, 1900: 4; and "A Pulpit Plea for the Black Race," Daily Picayune (New Orleans), August 20, 1900: 3.

282 "Vox Populi," Daily Picayune (New Orleans), July 6, 1900; and Hair, Carnival of Fury, 139.

283 "Separate Car Question," Daily Picayune (New Orleans), July 4, 1900, 3.
} 
its introduction...the act would have passed overwhelmingly." ${ }^{284}$ Wilson introduced a new bill as soon as possible, a priority, as, "The negroes are not subdued, and are as burly as ever." 285 The bill would eventually pass in the state legislature in 1902, officially segregating streetcars in all cities with a population of more than 50,000 (of which, Louisiana had one). ${ }^{286}$ New Orleans's streetcars were its last public space to be officially segregated, and it was in this act of the legislature that the city finally caught up to the rest of the South in segregation.

The Hennessy and Robert Charles Riots are examples of violence which had, throughout the changes of Reconstruction and Redemption, been more endemic to rural areas of the South than in New Orleans itself. This is especially true in the mob nature of these events, which serve as a sharp contrast to the rigid organization of the White League and the general peaceful status of the city throughout the 1880 s. A new generation of white New Orleanians had taken up the torch of the ex-Confederates behind the 1866 race riot at Mechanics Hall, the city's sole predecessor in indiscriminate mob brutality. While the young mob that had raged during the Robert Charles Riot lacked the ethos of the White League or the solemnity of Lost Cause organizations, the older generation's commitment to enshrining Confederate nostalgia was only growing. During the first reunion of the United Confederate Veterans in 1889, only 36 camps, or

\footnotetext{
284 "News and Notables at Local Hotels," Daily Picayune (New Orleans), October 15, 1900. 285 Ibid.

${ }^{286}$ Hair, Carnival of Fury, 139, 140.

It should be noted that in addition to New Orleans being the only city in the state with streetcars, the black population of New Orleans alone had exceeded 50,000 in 1870, 32 years before the passage of the bill. See: Blassingame, Black New Orleans, 242.
} 
local franchises, participated; by 1898, a crucial year in Louisiana's social history, 1,555 camps gathered in New Orleans. ${ }^{287}$

It is in evaluating the impacts of events like the Robert Charles Riot and the framework of Jim Crow that jazz history becomes crucial to a study of social conditions in New Orleans. Jazz is not necessarily just a cultural output of Jim Crow, but an effective means of viewing many subtle changes in the lives of black and white New Orleanians at the turn of the twentieth century. The experiences of the many musicians in this burgeoning movement, be they native New Orleanians exposed to the music's evolution throughout their lives, or rural Louisianans like Edward "Kid" Ory drawn to the city's lure of anonymity and relative safety when compared to the countryside like many black Southerners before them.

The recollections of the boastful but embittered Jelly Roll Morton describe New Orleans's early jazz era as one of easy social compromise. According to Morton “...there wasn't no certain neighborhood for nobody to live in in New Orleans.",288 Morton also states emphatically that, "there weren't any discrimination of any kind," at the dancehalls throughout the city, and, "[the audience] all sat at different tables or anywhere they felt like sitting. They all mingled together just as they wished to and everyone was just like one big happy family." ${ }^{289}$ If there is a grain of truth to Morton's descriptions, it might be best explained that racial-mixing under segregation was a one

\footnotetext{
${ }^{287}$ Hattaway, "Clio's Southern Soldiers," 214.

${ }^{288}$ Lomax, Mister Jelly Roll, 42.

${ }^{289}$ Ibid.
} 
way act; Morton's remembrances also give attention to slumming, in which wealthy, white New Orleanians would frequent rough establishments in the spirit of adventure. ${ }^{290}$

Other jazz musicians of the period do concede some social fluidity in the subculture of music, especially the spread of ideas and musical influence across the color line, but are perhaps more realistic in their descriptions of the racial tension under the Jim Crow order, citing Morton's black Creole heritage and fair skin as advantages he had over African American and dark complexioned black Creole musicians. ${ }^{291}$ Morton's recollections, even when viewed with suspicion, are evidence of the slow death of gray areas in the line between white and black in New Orleans; an event which has certainly muddled interpretation of the true impact of Jim Crow in the city as well as the role of ethnic whites and immigrants in a shifting social structure.

In the early 1900 s, the highly competitive music scene established in the $1890 \mathrm{~s}$ began placing greater importance on virtuosity than class. Buddy Bolden, perhaps one of the most important early jazz musicians, was an African American cornet player who competed with John Robichaux, a black Creole clarinetist, for gigs as well as renown. While the rivalry between black Creoles and African Americans was still entrenched, Bolden and Robichaux's respect for each others abilities and innovations led them to incorporate aspects of the other's style into their own music despite open animosity. ${ }^{292}$ Hesitant acceptance of talent as well as inspiration drawn from musicians on either side

${ }^{290}$ Lomax, Mister Jelly Roll, 52.

${ }^{291}$ Louis Armstrong, "Louis Armstong + the Jewish Family in New Orleans, La. The Year 1907," Louis Armstrong, in His Own Words: Selected Writings, ed. Thomas Brothers (Oxford: Oxford University Press, 1999), 24.

Prividges Morton may have experienced in New Orleans, where ethnicity still carried some weight as the city adjusted to bi-racial Jim Crow, become evident in Morton's surprise in finding more racism after leaving New Orleans for Northern cities. See Charles Hersch, Subversive Sounds, 166.

${ }^{292}$ Donald Marquis, In Search of Buddy Bolden, 79-82. 
of the Uptown-Downtown ethnic divide in the black population provides an important window into how these communities eventually reconciled; not before jazz, but, in some ways, through it. By 1914, the Creole Band, which would thoroughly tour the United States from 1914 to 1918, formed in New Orleans from a collection of musicians of diverse backgrounds, successfully blending African American and black Creole musicians (at least on stage). ${ }^{293}$

The childhood of Louis Armstrong, one of New Orleans's most celebrated jazz figures, is similarly a fascinating vantage into the city's social structure during Jim Crow. Born into an uptown African American family, Armstrong experienced not only the dangers but also the benefits of a dense, multi-ethnic neighborhood on the edge of New Orleans's famous red light district; a favorite childhood treat was dining out in the neighborhood's affordable Chinese restaurants. Most telling of the social dynamics in which Armstrong was raised is his close relationship with the family of Morris Karnofsky, an Eastern-European Jew who served as Armstrong's employer and mentor. In his memoirs, Armstrong professed that at the age of seven he was shocked by the realization that despite the palpable state of black-white relations in New Orleans, that, “even 'my race,' the Negroes...were having a little better luck than the Jewish people [emphasis in original]. ${ }^{, 294}$ Armstrong's rough upbringing and reliance on the Karnofskys is evidence not only of the dire economic standing of many black New

\footnotetext{
${ }^{293}$ Lawrence Gushee, Pioneers of Jazz: The Story of the Creole Band (Oxford: Oxford University Press, 2005), 23-59.

${ }^{294}$ Armstrong's relationship with the Karnofskys was profound; it was Morris Karnofsky who purchased Armstrong's first cornet. Armstrong's estimation of the strife encountered by this family serves as an effective contrast to the successful assimilation of Western-European Jews such as Judah P. Benjamin and E.B. Kruttschnitt. See chapter two, page 17, note 51.

Louis Armstrong, "Louis Armstrong + the Jewish Family in New Orleans, La., the Year 1907," 15.
} 
Orleanians, but also of another community cast down by the Jim Crow definition of racial order. Though Jewish New Orleanians had once been counted in the prominent circles of the Confederacy, the city's exclusive clubs and krewes, and in the drafting of the disenfranchising 1898 state constitution itself, the cementing of white supremacy at the turn of the century quickly eroded the remnants of previous acceptance of Jews among the white Protestant elite.

While Jewish and Sicilian musicians did contribute to early jazz music, their participation is as much a sign of their relative equal footing with African Americans and black Creoles under Jim Crow as of their musical prowess. Despite the ability of musicians and ordinary dancehall attendees alike to find cultural satisfaction beneath the strict segregation ushered in by the 1898 state constitution and its buttresses of civil codes and statutes, it was the musicians who led the migration northward at the turn of the twentieth century. The flight of jazz musicians from New Orleans after 1914, prompted both by the increased racial violence seen in the Robert Charles Riot and the lure of new audiences in Chicago, New York, and Los Angeles, foreshadowed a greater migration of black Americans, but also created issues for the musicians themselves as they tried to craft personas and reputations independent of the vast, complex cultural network of New Orleans. ${ }^{295}$

Daniel Desdunes, who had participated in his father Rodolphe Desdunes' Citizens Committee effort to test interstate railroad segregation in 1892 was also a member of this migration. The younger Desdunes had made a living as a professional musician in New Orleans, and there is evidence that he played in jazz bands before

${ }^{295}$ Hersch, Subversive Sounds: 166, 167. 
moving to Omaha, Nebraska to become a teacher and bandleader for African American youth and professional orchestras. ${ }^{296}$ That Rodolphe Desdunes' own son, nonetheless a member of the Citizens Committee's attack on segregation in transportation, would seek better social conditions elsewhere is confirmation not only of a general trend, but also of the changing perspective of the younger generation of black New Orleanians in the grim climate of Jim Crow.

For a time, at least, the fight for social and political equality was over, and traditional alternatives were chosen over overt political action. The emigration of jazz musicians from New Orleans, of course, held lasting impacts for the culture of the United States as a whole, and in the context of evaluating the changes in New Orleans society from Reconstruction to the imposition of Jim Crow, it represents a highly interesting example of social and cultural fallout from such a period of drastic and fluid change. While many musicians and other black New Orleanians did leave the city, a majority stayed to continue living in what remained a diverse, cosmopolitan city beneath

\footnotetext{
${ }^{296}$ Daniel Desdunes' role as a bandleader put him in a position of influence over local musicians who would become involved in the Kansas City jazz scene. Nathan W. Pearson, Jr., "Political and Musical Forces That Influenced the Development of Kansas City Jazz," Black Music Research Journal 9, No. 2 (Autumn 1989): 189.

For Desdunes' involvement in jazz in New Orleans, see: Lawrence Gushee, "The Nineteenth-Century Origins of Jazz," 166. For a glimpse at his career in Omaha, the following articles shed some light: "Desdunes' Academy," Morning World-Herald (Omaha), October 27, 1906: 10, http://infoweb.newsbank.com.proxy.lib.pdx.edu/iwsearch/we/HistArchive/?p_product=EANX\&p theme=ahnp\&p_nbid=C60M4EHLMTMyOTcxNDE1OS4 2ODYxNzQ6MToxMzoxMzEuMjUyLjk2LjI4\&p action=doc\&s_lastnonissuequeryname $=5 \& d$ viewref $=$ search\&p_queryname $=5 \& p \_$docnum $=3 \& p \_$docref=v2:1106B5BBD4B623A8@EANX1172B5331A977EC0@2417511-1172B534758241E8@,91172B53953B68628@Desdunes\%27+Academy (accessed January 11, 2012); "Reception to Hogan," Morning World-Herald (Omaha) May 5, 1906:11, http://infoweb.newsbank.com.proxy.lib.pdx.edu/iwsearch/we/HistArchive/?p_product=EANX\&p theme $=$ ahnp\&p_nbid=C60M4EHLMTMyOTcxNDE1OS4 2ODYxNzQ6MToxMzoxMzEuMjUyLjk2LjI4\&p_action=doc\&s_lastnonissuequeryname $=5 \& d$ viewref $=$ search\&p_queryname $=5 \& p \_$docnum $=1 \& p \_$docref $=\mathrm{v} 2: 1106 \mathrm{~B} 5 \mathrm{BBD} 4 \mathrm{~B} 623 \mathrm{~A} 8 @$ EANX1128F0C642DFA820@,2417336-1128F0C91C3DD3F0@10-

1128F0CFDC54C308@Reception+to+Hogan (accessed January 11, 2012).
} 
the structure of codified segregation. New Orleans's vast cultural outlets would continue to be vital to a wide cross section of residents up to the present, though the impending decades of rigid segregation have made their origins and meanings mysterious. In continuing to explore these elements of society, New Orleans retains one of its defining characteristics, the surprising nature of its own complexity. 


\section{Conclusion}

Jim Crow was not a single idea, statute, or social more. As described in the previous chapters, it was instead a vast bulwark of related restrictions, layered in the state constitution, the laws which relied upon it, the court cases which legitimized them, and in the changing expectations of white citizens fostered by such legislation. This framework was expanded in the twentieth century. After the segregation of New Orleans streetcars in 1902, Louisiana became the last state of the old Confederacy to ultimately ban interracial relationships five years later. ${ }^{297}$ With legal segregation complete in the twentieth century, the cultural consequences of the law grew. In 1915, the Louisiana Historical Society laid to rest the question of the definition of the word Creole; the meaning of which had been hotly contested by George Washington Cable and Charles Gayarré throughout the late nineteenth century. Relying on the scholarship of Alcée Fortier, a protégé of Gayarré, the society established a disconnect between the white and black Creoles which not only negated the ethnic pride of such black Creoles as Rodolphe Desdunes, but also took decades for future scholars to reassess. ${ }^{298}$

The contributions of the black Creole community to the ultimately unsuccessful civil rights movements of the late nineteenth century, including Reconstruction and the last great push of the Citizens Committee, were not, in the words of Joseph Logsdon and Caryn Cossé Bell, a "prolonged fool's errand” fighting against the inevitable. ${ }^{299}$ The black Creole political legacy is an admirable one, and even in defeat it stands as a

\footnotetext{
${ }^{297}$ Cohen, At Freedom's Edge: 215.

298 Tregle, "Creoles and Americans,":183.

${ }^{299}$ Logsdon and Bell, “The Americanization of Black New Orleans, 1850-1900," In Creole New Orleans: Race and Americanization, 260.
} 
powerful example of the complex nature of New Orleans's adaptation to a bi-racial order. In chapter one, the extraordinary agency of this community was discussed not only to describe its many temporary successes, but to open inquiries into why it was not ultimately successful. In its favor this community could rely on the institution of federal Reconstruction, a varied mix of moderate and radical whites, and the traditionally cosmopolitan culture and increasing ethnic diversity of New Orleans. However, the inability to form connections with the growing community of African Americans, as well as an economic-class based perspective, proved to be devastating handicaps when contrasted with the highly effective strategy of reactionary white elites in the Democratic Party.

Black Creoles failed in their attempts at achieving social equality because they never reconciled their historical, religious, and social differences with the African American class. Conversely, white elites were able to realize, after decades of slowly building cultural consensus, the effective consolidation of ethnic whites in New Orleans, through shared celebration of the movement which defined them; the Lost Cause of the Confederacy. Crucial to this effort of consolidation was the indoctrination, by way of manipulation the white community's understanding of historical events, of younger generations to take up the cause of reactionary Democrats ardent at re-establishing a society which had not, in such stark terms, previously existed. Chapters two and three each found connections in this theme to key events in New Orleans history, and describe not only the influence of reactionary Confederate veterans, their organizations and 
publications, but also those influences' effect on subsequent younger generations of white New Orleanians.

The reordering of society in the implementation of Jim Crow segregation was of great consequence to ethnic immigrants who fell outside the scope of white consolidation executed by the Democratic Party and white elite. While the status of Jewish and Sicilian New Orleanians in the late nineteenth century is well known, this thesis connects the precarious social status of those communities to trends apparent in the worsening racial relations of the period. In erecting a starkly black and white social order in a city that presents such a multitude of gray areas, these two communities were cast aside. For the Jewish community of New Orleans, this loss of status is relatively comparable to the loss of status suffered by the black Creoles. In answering the question of where the public ambition of this community of color was directed after Plessy $v$. Ferguson, New Orleans's semi-autonomous black cultural institutions were shown to be the recipients. Study of the social institutions of the black community, both within and between the black Creole and African American classes, and the importance of participation in dynamic cultural traditions provides insight into the eventual reconciliation between the black Creole and African American communities, a process which was just beginning at the start of the twentieth century.

The wide scope of this thesis in giving consideration to the trials of the white, black Creole, African American, and ethnic immigrant communities concurrently was selected in part to aid in connecting the scholarly work which existed in various fields, but also to give appropriate attention to the complex nature of New Orleans's society 
and culture. New Orleans has always been a city in which the gray areas of social constructs within the larger colonial, Southern, or American social organizations go to shine, but its uniqueness does not qualify it for irrelevancy. Thusly, this work stands in agreement with the perspectives of Nancy Hewitt and Alecia P. Long in insisting that while New Orleans may present a great deal more complexities than other, more homogenous Southern cities and regions, ignoring those complexities diminishes a complete understanding of important trends in Southern, much less American, history.

This thesis similarly sought to give attention to the many New Orleanians whose perspectives and careers, though distinctive, contribute to a better understanding of New Orleans society and culture throughout the period. Hence, discussions of George Washington Cable, Hamilton Dodley Coleman, and General James Longstreet were used to give important contrast to the influence of the White League and Regular Democrats. The role of white moderates can be difficult to assess after Redemption, but the intercession of several whites in attempts to stop the violence of the Robert Charles Riot and protect black New Orleanians during a period of drastic racial violence across the South begs for such further exploration as provided in chapters two and three. Perhaps more importantly, this thesis provided discussions of the role of ethnic immigrant communities in New Orleans during the period, a topic that has received relatively little scholarly coverage. The inclusion of explorations of the Jewish and Sicilian communities roles in the period does not simply serve as context to the city's shift from an ethnically stratified society to a bi-racial order, but gives greater insight into how the 
process of white consolidation worked as well as how the reactionary sentiments behind Jim Crow segregation effected the wider society of New Orleans.

It has been with great difficulty that scholars have attempted to reconcile descriptions of New Orleans's live-and-let-live mentality, its ground-level accommodations of racial and ethnic diversity, and the development of jazz with the realities of increasing segregation and episodes of racial and ethnic violence. This thesis has relied, like many of the works that influenced and informed it, on emphasizing the complexity of New Orleans society in explaining how one city could produce such a multi-faceted narrative of struggle, compromise, and cultural empowerment. In doing so, this thesis has attempted to provide future researchers with a more complete and contextual platform from which to view the myriad of relationships, motivations, and social dynamics that shaped New Orleans's path from the promise of the 1868 state constitution to the indiscriminate racial retribution of the Robert Charles Riot of 1900. 
Bibliography

\section{Primary Sources}

Manuscript Sources:

Alexander Pierre Tureaud Papers (1859-1972) Box\#77, Amistad Research Center, Tulane University.

Charles B. Rousseve Collection, 1902-1993 Papers: 1836-1993, Amistad Research Center, Tulane University.

Louisiana Division and Special Collections, New Orleans Public Library.

Law Library of Louisiana, Louisiana Supreme Court.

Court Cases:

Decuir v. Benson. 27 La. Ann. 1, 1875 WL 263, No. 4829

Ex parte Plessy. 45 La. Ann. 80, 11 So. 948.

Plessy v. Ferguson. 163 US 537 (1896).

State of Louisiana v. Daniel F. Desdunes, $18685.2^{\text {nd }}$ Recorders Court, City of New Orleans, 1892.

Legal Documents:

Louisiana Constitution of 1898

Louisiana Constitution of 1868

Municipal Ordinance 624 CS (1877) New Orleans, http://www.nutrias.org/ nopl/inv/synopsis/c.htm (accessed December 1, 2011).

Municipal Ordinance 7065 AS (1881) New Orleans,

http://www.nutrias.org/ nopl/inv/synopsis/c.htm (accessed December 1, 2011).

Newspapers:

The New York Times. ProQuest Historical Newspapers.

New Orleans Daily Picayune 
New Orleans Crusader

Contemporary publications:

Louis A. Martinet, ed., The Violation of a Constitutional Right, (New Orleans: The Crusader Print, 1893): 6.

George Frisbie Hoar, W.H. Wheeler, and Wm. P. Frye, "The White League in Louisiana: Examined by the light of White League Testimony," (New Orleans, 1875),

Hugh J. Campbell, The White League Conspiracy Against Free Government (New Orleans: New Orleans Republican press, January 17, 1875).

J. Dickson Bruns, M.D., Address to the White League of New Orleans (New Orleans: A.W. Hyatt, Stationer and Printer, 1875)

Republished contemporary publications:

Ida B. Wells-Barnett. "Mob Rule in New Orleans," in On Lynchings: Southern Horrors, A Red Record, Mob Rule in New Orleans. New York: Arno Press, 1969.

Louis Armstrong, "Louis Armstong + the Jewish Family in New Orleans, La. The Year 1907," Louis Armstrong, in His Own Words: Selected Writings, ed. Thomas Brothers (Oxford: Oxford University Press, 1999

Cable, George Washington. "My Politics," The Negro Question: A Selection of Writings on Civil Rights in the South by George Washington Cable, ed. Arlin Turner (Garden City, NY: Doubleday, 1958)

George Washington Cable, "The Freedman's Case in Equity," The Silent South (Montclaire, NJ: Patterson Smith, 1969) 


\section{Secondary Sources}

Bailey, Fred Arthur, "The Textbooks of the 'Lost Cause': Censorship and the Creation of Southern State Histories," The Georgia Historical Quarterly 75 No. 3 (Fall 1991).

Bell, Caryn Cossé. Revolution, Romanticism, and the Afro-Creole Protest Tradition in Louisiana: 1718-1868. Baton Rouge: Louisiana State University Press, 1997.

Bernstein, Barton J., "Case Law in Plessy v. Ferguson," The Journal of Negro History 47, No. 3 (July, 1962).

Blassingame, John W. Black New Orleans: 1860-1880. Chicago: University of Chicago Press, 1973.

Blight, David W. Race and Reunion: The Civil War in American Memory. Cambridge, MA: Belknap Press, 2001.

Cable, George Washington, “The 'Haunted House' in Royal Street," In Strange True Stories of Louisiana. Gretna, LA: Pelican Publishing, 1994.

Campanella, Richard, "An Ethnic Geography of New Orleans," Journal of American History 94, No. 3 (December 2007).

Charters, Samuel. A Trumpet Around the Corner: The Story of New Orleans Jazz (Jackson, University Press of Mississippi, 2008).

Cohen, William. At Freedom's Edge: Black Mobility and the Southern White Quest for Racial Control, 1861-1915. Baton Rouge: Louisiana State University Press, 2005.

Collins, R. New Orleans Jazz: A Revised History: The Development of American Music from the Origin to the Big Bands. New York: Vintage Press, 1996.

Dailey, Jane. Before Jim Crow: The Politics of Race in Postemancipation Virginia (Chapel Hill: The University of North Carolina Press, 2000).

— , "The Limits of Liberalism in the New South: The Politics of Race, Sex, and Patronage in Virginia, 1879-1883," in Jumpin' Jim Crow: Southern Politics from Civil War to Civil Rights Edited by Jane Dailey, Glenda Elizabeth Gilmore, and Bryant Simon (Princeton: Princeton University Press, 2000). 
Desdunes, Rodolphe Lucian, Our People and Our History: Fifty Creole Portraits. Translated and edited by Sister Dorothea Olga McCants. Baton Rouge: Louisiana State University Press, 1973.

Doorly, Michael, "Irish Catholics and French Creoles: Ethnic Struggles within the Catholic Church in New Orleans, 1835-1920," The Catholic Historical Review 87, No. 1 (2001).

Elliott, Mark. "Race, Color Blindness, and the Democratic Public: Albion W. Tourgée's Radical Principles in Plessy v. Ferguson," The Journal of Southern History 67 No. 2 (May 2001).

Ferris, Marcie Cohen and Mark I. Greenberg, ed. Jewish Roots in Southern Soil: A New History. (Watham, MA: Brandeis University Press, 2006).

Gambino, Richard. Vendetta: A True Story of the Worst Lynching in America, the Mass Murder of Italian-Americans in New Orleans in 1891, the Vicious Motivations Behind It, and the Tragic Repercussions That Linger to this Day. New York: Double Day and Co., 1977.

"General G.T. Beauregard," Art Inventories Catalog, Smithsonian American Art Museum, Smithsonian Institution Research Information System, listed under "Doyle, Alexander," www.siris.si.edu (accessed 1/10/2012).

Gill, James G. Lords of Misrule: Mardi Gras and the Politics of Race in New Orleans. Jackson: University Press of Mississippi, 1997.

Gushee, Lawrence, “The Nineteenth-Century Origins of Jazz,” Black Music Research Journal 22 (2002)

- Pioneers of Jazz: The Story of the Creole Band. Oxford: Oxford University Press, 2005.

Haas, Edward F. Political Leadership in a Southern City: New Orleans in the Progressive Era, 1896-1902. Ruston, LA: McGinty Publications, 1988.

Hair, William Ivy Carnival of Fury: Robert Charles and the New Orleans Race Riot of 1900. Baton Rouge: Louisiana State University Press, 1986.

Harlan, Louis R. "Desegregation in New Orleans Public Schools During Reconstruction," In African American Life in the Post-Emancipation South, 1861-1900. Edited by Donald G. Nieman. New York: Garland, 1994. 
Hattaway, Herman, "Clio's Southern Soldiers: The United Confederate Veterans and History," Louisiana History 12, No. 3 (Summer 1971).

Hennessey, Thomas J. From Jazz to Swing: African-American Jazz Musicians and Their Music, 1890-1935. Detroit: Wayne State University Press, 1994.

Hersch, Charles. Subversive Sounds: Race and the Birth of Jazz in New Orleans. Chicago: University of Chicago Press, 2007.

Hirsch, Arnold R. and Joseph Logsdon, ed. Creole New Orleans: Race and Americanization. Baton Rouge: Louisiana State University Press, 1992.

Hollandsworth, James G., Jr. The Louisiana Native Guards: The Black Experience During the Civil War. Baton Rouge: Louisiana State University Press, 1995.

Houzeau, Jean-Charles. My Passage at the New Orleans Tribune: A Memoir of the Civil War Era. Edited by David C. Rankin. Baton Rouge: Louisiana State University Press, 1984.

Ingham, John N. and Lynne B. Feldman, “Cohen, Walter I.," In African-American Business Leaders: A Biographical Dictionary. Westport, CN: Greenwood Press, 1994.

Jackson, Joy J. New Orleans in the Gilded Age: Politics and Urban Progress, 1880-1896. Baton Rouge: Louisiana State University Press, 1969.

Jacobs, Claude F., "Benevolnet Societies of New Orleans Blacks during the Late Nineteenth and Early Twentieth Centuries," Louisiana History 29, No.1 (Winter, 1988).

Jacobson, Matthew Frye. Whiteness of a Different Color: European Immigrants and the Alchemy of Race. Cambridge, MA: Harvard University Press, 1998.

LaChance, Paul F. "The 1809 Immigration of Saint-Domingue Refugees to New Orleans: Reception, Integration and Impact" Louisiana History 29. No. 2(Spring 1988).

Landry, Stuart Omer. The Battle of Liberty Place; The Overthrow of Carpet-bag Rule in New Orleans, September 14, 1874 (Gretna, LA: Pelican Publishing, 1955).

Langston, Scott M., "Jews and Christians in Nineteenth Century New Orleans," In Dixie Diaspora: An Anthology of Southern Jewish History. Edited by Mark K. Bauman. Tuscaloosa: University of Alabama Press, 2006. 
Lipsitz, George, "Mardi Gras Indians: Carnival and Counter Culture Narrative in Black New Orleans," Cultural Critique 10 (Autumn 1988).

Lofgren, Charles A., The Plessy Case: A Legal Interpretation (New York: Oxford University Press, 1987).

Lomax, Alan. Mister Jelly Roll: The Fortunes of Jelly Roll Morton, New Orleans Creole and "Inventor of Jazz." Berkeley: University of California Press, 1973.

Long, Alecia P. The Great Southern Babylon: Sex, Race, and Respectability in New Orleans, 1865-1920. Baton Rouge: Louisiana State University Press, 2004.

Magnaghi, Russell M. “Louisiana’s Italian Immigrants Prior to 1870” Louisiana History 27, No. 1 (Winter 1986).

Marquis, Donald M. In Search of Buddy Bolden: First Man of Jazz. Baton Rouge: Louisiana State University Press, 1978.

McKnight, Mark, "Charivaris, Cowbellions, and Sheet Iron Bands: Nineteenth-Century Rough Music in New Orleans," American Music 23, No.4 (Winter 2005)

Medley, Keith Wledon. We as Freemen: Plessy v. Ferguson. Gretna, LA: Pelican Publishing, 2003.

Mehrlander, Andrea, “'With More Freedom and Independence than the Yankees,' The Germans of Richmond, Charleston, and New Orleans during the American Civil War," In Civil War Citizens: Race, Ethnicity, and Identity in America's Bloodiest Conflict. Edited by Susannah J. Ural. New York: New York University Press, 2010.

Olsen, Otto H., Editor. The Thin Disguise: Turning Point in Negro History: Plessy v. Ferguson: A Documentary Presentation, 1864-1896. New York: Humanities Press, 1967.

Palmore, Joseph R. "The Not-So-Strange Career of Interstate Jim Crow: Race, Transportation, and the Dormant Commerce Clause," Virginia Law Review 83 No.8 (November 1997).

Panetta Vincent J., "“For Godsake Stop!' Improvised Music in the Streets of New Orleans, ca. 1890," Musical Quarterly 84 no. 1 (2000), http://www.mq.oxfordjournals.org (accessed October 19, 2010).

Pearson, Nathan W., Jr., "Political and Musical Forces That Influenced the Development of Kansas City Jazz,” Black Music Research Journal 9, No. 2 (Autumn 1989). 
Peretti, Burton W. The Creation of Jazz: Race, Music, and Culture in Urban America. Urbana: University of Illinois Press, 1994.

Powell, Lawrence N. "Reinventing Tradition: Liberty Place, Historical Memory, and Silk-stocking Vigilantism in New Orleans Politics," In From Slavery to Emancipation in the Atlantic World. Edited by Sylvia R. Frey and Betty Wood. London: Frank Cass Publishers, 1999.

Rankin, David Connell, "The Forgotten People: Free People of Color in New Orleans, 1850-1870.” PhD diss., Johns Hopkins University, 1976. Xerox University Microfilms, 1977.

Richter, William L., "James Longstreet: From Rebel to Scalawag,” Louisiana History 11 No. 3 (Summer 1970).

Ross, Michael A. “Justice Miller's Reconstruction: The Slaughter-House Cases, Health Codes, and Civil Rights in New Orleans," The Journal of Southern History, 64 No. 4 (Nov. 1998).

Rousey, Dennis C. Policing the Southern City: New Orleans, 1805-1889. Baton Rouge: Louisiana State University Press, 2001.

Schechter, Patricia A. Ida B. Wells-Barnett and American Reform, 1880-1930 (Chapel Hill: The University of North Carolina Press, 2001).

Scott, Rebecca J. "Public Rights, Social Equality, and the Conceptual Roots of the Plessy Challenge," Michigan Law Review, 106 (March 2008).

—. Degrees of Freedom: Louisiana and Cuba After Slavery. Cambridge, MA: The Belknap Press of Harvard University Press, 2005.

Somers, Dale A., "Black and White in New Orleans," Journal of Southern History 40, No. 1 (Feb. 1974).

Thompson, Shirley Elizabeth. Exiles at Home: The Struggle to Become American in Creole New Orleans. Cambridge, MA: Harvard University Press, 2009.

Tregle, Joseph G. "Early New Orleans Society: A Reappraisal," Journal of Southern History 18, No.1 (February 1952)

—_. "On That Word 'Creole’ Again: A Note," Louisiana History 23, No. 2 (Spring 1982). 
Tunnell, Ted, "Creating 'The Propoganda of History': Southern Editors and the Origins of 'Carpetbagger and Scalawag," The Journal of Southern History 72 No. 4 (Nov. 2006).

- Crucible of Reconstruction: War, Radicalism, and Race in Louisiana 1862-1877. Baton Rouge: Louisiana State University Press, 1984.

Turner, Richard Brent Jazz Religon, the Second Line, and Black New Orleans. Bloomington: Indiana University Press, 2009.

Urquhart, Kenneth Trist, "Seventy Years of the Louisiana Historical Association," presented March 21, 1959. Louisiana Historical Association website, http://www.lahistory.org/uploads/UrquhartLHAHistoryFinal.pdf (accessed December 3, 2011).

Usner, Daniel Jr. Indians, Settlers, and Slaves in a Frontier Exchange Economy: The Lower Mississippi Valley Before 1783. Chapel Hill: University of North Carolina Press, 1992.

Van Deusen, John G., “The Exodus of 1879," Journal of Negro History 21 No. 2 (April 1936).

Wallenstein, Peter, "Reconstruction, Segregation, and Miscegenation: Interracial Marriage and the Law in the Lower South, 1865-1900," American Nineteenth Century History 6, No.1 (March 2005).

"Werlein, Philip;" "Werlein, Philip Peter," Dictionary of Louisiana Biography, Louisiana Historical Association, http://www.lahistory.org/site40.php (accessed November 10, 2011).

Williams, T. Harry, “The Louisiana Unification Movement of 1873," Journal of Southern History 11, No. 3 (Aug. 1945).

Williamson, Joel. Crucible of Race: Black-White Relations in the American South Since Emancipation (New York: Oxford University Press, 1984).

Woodward, C. Van. The Strange Career of Jim Crow (Oxford: Oxford University Press, 2002). 